\title{
The Tauride Ophiolites of Anatolia (Turkey): A Review
}

\author{
Osman Parlak* \\ Çukurova Üniversitesi, Jeoloji Mühendisliği Bölümü, Balcalı, Adana 01380, Turkey
}

\begin{abstract}
The Tauride ophiolites lie on the northern and southern flanks of an E-W-trending Tauride carbonate platform. They mainly consist of three tectonic units namely in ascending order, ophiolitic mélange, sub-ophiolitic metamorphic sole and oceanic lithospheric remnants. They were generated above intra-oceanic subduction zones and emplaced over the Tauride carbonate platform from different Neotethyan oceanic basins in the Late Cretaceous. Tauride ophiolites from west to east are described and reviewed. All are underlain by well-preserved dynamothermal metamorphic soles of varied structural thicknesses up to $500 \mathrm{~m}$ that have a constant structural position between ophiolitic mélange below and harzburgitic mantle tectonites above and display typical inverted metamorphic sequences from amphibolite facies above to greenschist facies below. The metamorphic soles are shown to have evolved during the initiation of subduction and emplacement processes. In the PozantlKarsantı area the contact between the metamorphic sole and the overlying serpentinized harzburgites is characterized by a 1.5-2-m-thick zone of sheared serpentinized harzburgitic mantle intercalated with amphibolites and cut by thick mafic dykes $(7-8 \mathrm{~m})$ which postdate intraoceanic metamorphism and high-temperature ductile deformation. This contact is interpreted as an intra-oceanic decoupling surface along which volcanics from the upper levels of the down-going plate were metamorphosed to amphibolite facies and accreted to the base of the hanging wall plate. The metamorphic soles and overlying ophiolitic rocks were intruded by numerous isolated post-metamorphic diabase dykes filled by island arc tholeiitic magma. Subduction initiation and roll-back processes best explain the structural and petrological relationships of Late Cretaceous ophiolite genesis, metamorphic sole formation and subsequent dyke emplacement of the Tauride ophiolites.
\end{abstract}

KEY WORDS: ophiolite, metamorphic sole, dyke emplacement, roll-back, subduction initiation.

\section{O INTRODUCTION}

The Tauride orogenic belts of Turkey are interpreted as representing a continental fragment that rifted from Gondwana (North Africa) during the Triassic, followed by reamalgamation and continental collision during the OligoMiocene (Karaoğlan et al., 2016) or Miocene (Okay et al., 2010). The Taurides are traditionally divided into three contiguous parts; the western, central and eastern Taurides (Özgül, 1976).

Ophiolites along the Tauride belt start with the Lycian nappes to the west and end with the Divriği ophiolite to the east (Fig. 1). These ophiolites (the Lycian nappes, Antalya, Beyşehir-Hoyran nappes, Mersin, Alihoca, Pozant1Karsantı, Pınarbaşı and Divriği) are situated either on the northern or on the southern flank of an approximately EW trending Tauride carbonate platform axis (Juteau, 1980). Individual ophiolites mainly consist of three tectonic units; in ascending order, ophiolitic mélange, sub-ophiolitic metamorphic sole and oceanic lithospheric remnants (mantle

\footnotetext{
*Corresponding author: parlak@cukurova.edu.tr

(c) The Author 2016. This article is published with open access at Springerlink.com
}

Manuscript received June 10, 2016.

Manuscript accepted October 7, 2016. tectonites and cumulates) (Juteau, 1980). The plutonic sections and the metamorphic soles of the Tauride ophiolites are cut by numerous isolated microgabbro-diabase and minor pyroxenite dykes at different structural levels (Robertson et al., 2013; Bağcı and Parlak, 2009; Çelik and Chiaradia, 2008; Çelik, 2007; Çelik and Delaloye, 2003; Elitok, 2001; Dilek et al., 1999; Parlak and Delaloye, 1996; Whitechurch et al., 1984; Juteau, 1980). The isolated dykes are not deformed, indicating that they were emplaced shortly after formation of the metamorphic soles, but they do not extend into the underlying mélanges and platform carbonates. Dyke emplacement therefore postdated formation of the ophiolites and metamorphic soles but predated final obduction onto the Tauride-Anatolide Platform. There is a general consensus among authors that the ophiolites along the Tauride belt were formed in supra-subduction zone (SSZ) settings and emplaced in the Late Cretaceous as a result of series of collisions of intraoceanic arc-trench systems with the continental margins of different oceanic basins namely İzmir-Ankara-Erzincan (İAE), inner Tauride (IT) and southern Neotethys (Çelik and Chiaradia, 2008; Elitok and Drüppel, 2008; Çelik, 2007; Bağc1 et al., 2006; Parlak et al., 2002, 2000, 1996; Vergili and Parlak, 2005; Robertson, 2004; Çelik and Delaloye, 2003; Andrew and Robertson, 2002; Elitok, 2001; Dilek et al., 1999; Collins and Robertson, 1998, 1997; Dilek and Whitney, 1997; Parlak and

Parlak, O., 2016. Tauride Ophiolites in Anatolia (Turkey): A Review. Journal of Earth Science, 27(6): 901-934. doi:10.1007/s12583-016-0679-3. http://en.earth-science.net 


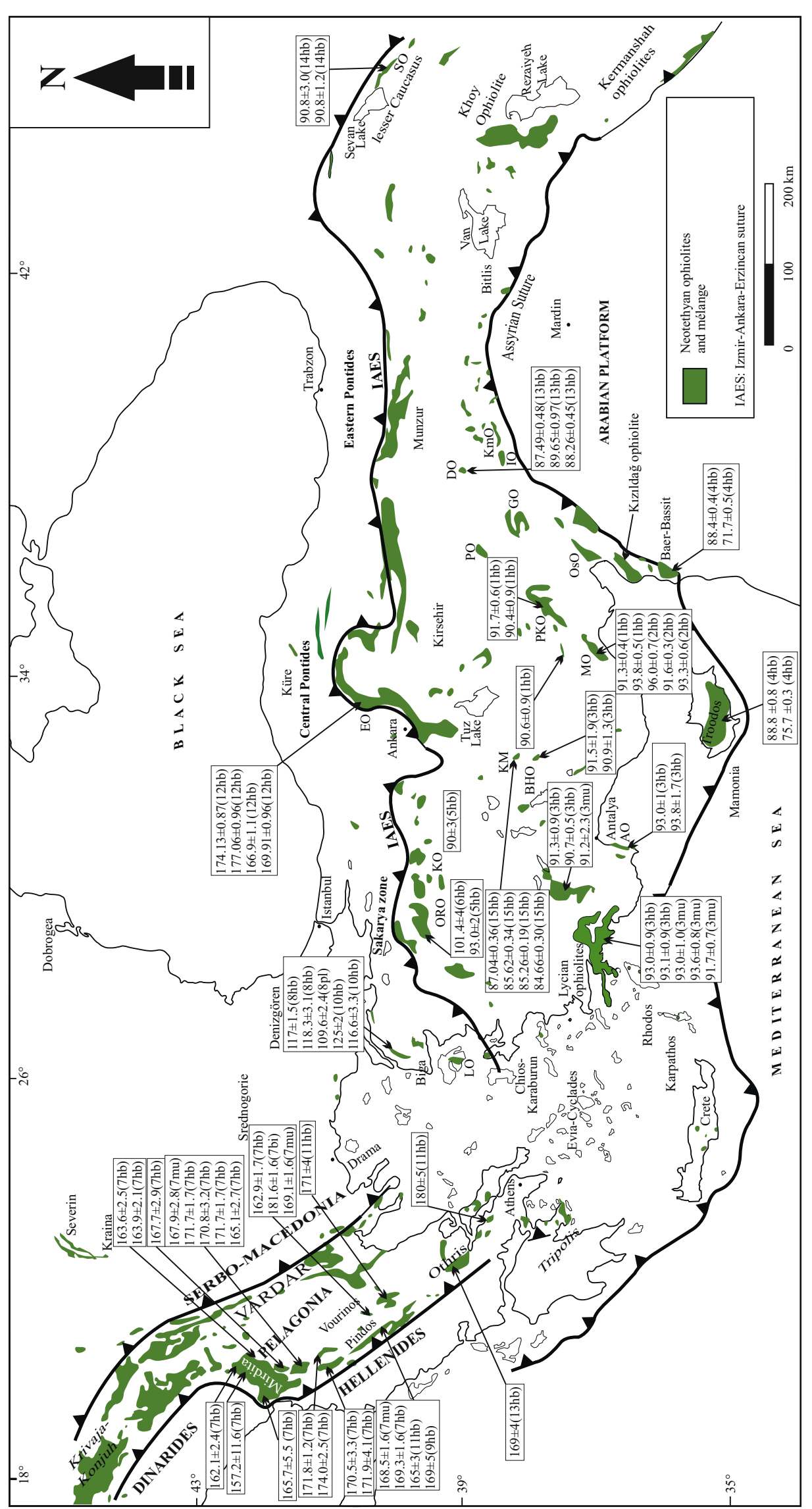

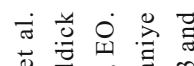

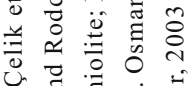

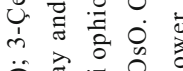

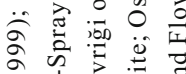
$\stackrel{2}{ \pm} \div$

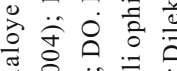

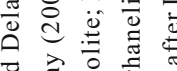

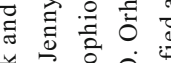

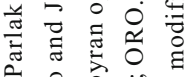

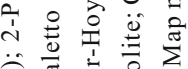

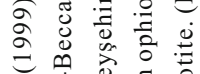
बढ ए

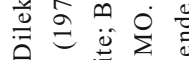

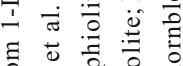

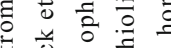
0 웜

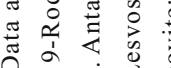
0 ○े 政 के

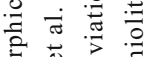
政

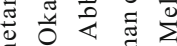

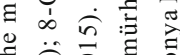
苍言唔 过

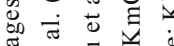

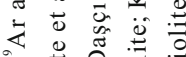

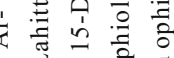

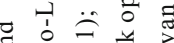

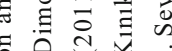

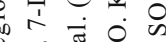
产苛 ฮू

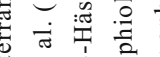
형

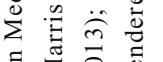

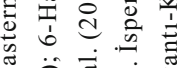

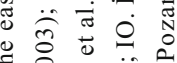
过芯过 a $\frac{1}{5} \frac{\pi}{5}$

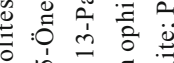
产望言 प웡 वे 잉 造宁过

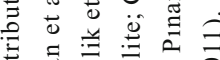

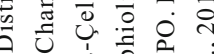

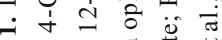

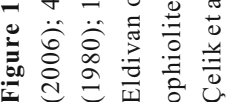


Delaloye, 1996; Robertson and Woodcock, 1982, 1981a, b, c).

The Tethyan ophiolites are structurally underlain by thin sheets of high-grade metamorphic sole rocks (Jamieson, 1986; Robertson and Dixon, 1984; Spray, 1984; Williams and Smyth, 1973). Initiation of subduction and formation of metamorphic soles have been linked to the ophiolite emplacement process (Hacker et al., 1996; Jamieson, 1986, 1980; McCaig, 1983; Williams and Smyth, 1973). The subophiolitic metamorphic soles along the Tauride belt are structurally beneath the mantle tectonites and did not experience any later tectonic effects such as re-heating because they have yielded constant well-constrained Late Cretaceous ${ }^{40} \mathrm{Ar} /{ }^{39} \mathrm{Ar}$ plateau ages (Çelik et al., 2006; Dilek et al., 1999; Parlak and Delaloye, 1999). The post-metamorphic dykes display a similar Late Cretaceous tectono-thermal history (Dilek et al., 1999; Parlak and Delaloye, 1996).

A number of tectonic models have been proposed for the Tauride belt ophiolites to account for the oceanic lithosphere generation, metamorphic sole formation, dyke emplacement and subsequent ophiolite emplacement onto the Tauride Platform (Çelik and Chiaradia, 2008; Elitok and Drüppel, 2008; Çelik, 2007; Çelik and Delaloye, 2006; Parlak et al., 2006; Parlak and Robertson, 2004; Andrew and Robertson, 2002; Dilek et al., 1999; Collins and Robertson, 1997; Dilek and Whitney, 1997; Polat et al., 1996; Lytwyn and Casey, 1995). All authors agree that metamorphic soles were derived from ocean island basalts (OIB), mid-ocean ridge basalts (MORB), island arc tholeiite (IAT) basalts and associated sediments at the beginning of intra-oceanic subduction of the downgoing plate and indicate the presence of SSZ-type crust on the overriding plate. The post-metamorphic dyke emplacement through the metamorphic soles and oceanic lithosphere is proposed as the result of (a) ridge-subduction (Polat et al., 1996; Lytwyn and Casey, 1995), (b) slab break-off (Çelik, 2007; Parlak et al., 2006), (c) multiple intra-oceanic thrusting and emplacement events in small oceanic basins (Çelik and Chiaradia, 2008; Çelik, 2007), and (d) asymmetrical ridge collapse (Dilek et al., 1999). It is difficult to explain the dyke emplacement into the metamorphic soles in any of these models, because there is a space problem with the sites of the metamorphic soles and the origin of the melts that contributed to accretion of SSZ-type oceanic lithosphere.

My objectives here are to (a) summarize the current state of knowledge of the Tauride belt ophiolites, (b) present new observations particularly on the mantle tectonites, metamorphic soles and dykes, (c) discuss the existing models for the metamorphic sole formation and dyke emplacement, and (d) propose a new tectonic model that reconciles genesis of ophiolites, metamorphic soles and subsequent dyke emplacement.

\section{TAURIDE OPHIOLITES}

In this section geological, petrological and geochronological data on ophiolites from the western to eastern Taurides will be presented together with recent unpublished observations. A summary of the Tauride ophiolites is given in Table 1.

\subsection{Lycian Ophiolites}

The well-known Lycian nappes are an important part of the Tethyan orogenic belt in southwest Turkey and have been the focus of research since the early 1970's (Collins and Robertson, 1999, 1997; Okay, 1989; Şenel et al., 1989; Poisson, 1977; De Graciansky, 1972). Five major tectonostratigraphic units have been defined in ascending order as: (1) the autochthonous basement (Menderes metamorphic complex and Beydağları Platform), (2) the carbonate-dominated Lycian thrust sheet, (3) the Lycian mélange, (4) the Lycian ophiolites and (5) a Paleogene transgressive unit above the Lycian mélange (Collins and Robertson, 1999, 1997).

The Lycian ophiolites in SW Turkey are mainly exposed in the Köyceğiz (Muğla) and Yeşilova (Burdur) regions (Figs. 2, 3). In both regions, the Lycian ophiolites display similar tectonostratigraphy to other ophiolites along the Taurides (Fig. 4). The Lycian mélange consists of two intergradational subunits, a layered tectonic mélange and an ophiolitic mélange (Collins and Robertson, 1997). The mélange sub-units are unconformably overlain by Paleocene to Eocene shallow water limestones (Şenel et al., 1989; Poisson, 1977). The mélange unit and the overlying limestones interleaved due to Eocene thrusting (Collins and Robertson, 1997). The layered tectonic mélange is mainly composed of thrust sheets of pelagic limestones that are separated by fragmented radiolarian cherts, black metalliferous cherts and litharenites set in a greenish clay matrix, with top to the southeast shear sense indicators (Collins and Robertson, 1999). The layered tectonic mélange is tectonically overlain by an ophiolitic mélange that consists of blocks of siliceous marble, basalt, gabbro, radiolarian chert and peridotite in a highly-deformed matrix of conglomerate, siltstone, claystone and sandstone (Collins and Robertson, 1999, 1997). A semi-coherent sheet of Mesozoic neritic limestone unit is also enclosed within the ophiolitic mélange. Blocks of basaltic volcanics within the ophiolitic mélange have mid-ocean-ridge (MOR) to within plate geochemical affinities (Collins and Robertson, 1997; Sarp, 1976). The Lycian mélange has been interpreted as an accretionary complex emplaced in the Late Cretaceous (Collins and Robertson, 1997).

Metamorphic sole rocks in the Yeşilova (Burdur) region are exposed beneath mantle tectonites northwest of Salda Lake, where they generally strike N-S and dip E/W (Fig. 3). They display granoblastic to lepidoblastic textures and are characterized by amphibolite, plagioclase amphibolite, amphibole schist, epidote-plagioclase amphibolite, calcschist, quartz-mica schist and marble (Sarp, 1976). The metamorphic sole is cut by $1.5-3 \mathrm{~m}$ isolated thick diabase dykes in the Değirmendere valley (Fig. 3). In the Köyceğiz (Muğla) region, a tectonic contact between the metamorphic sole and mantle tectonites is intruded by a post-metamorphic diabase dyke (Figs. 5a, 5b). The metamorphic sole beneath the mantle tectonites exhibits well developed foliation, dipping northwards $\left(090^{\circ} / 40^{\circ} \mathrm{N}\right)$ 


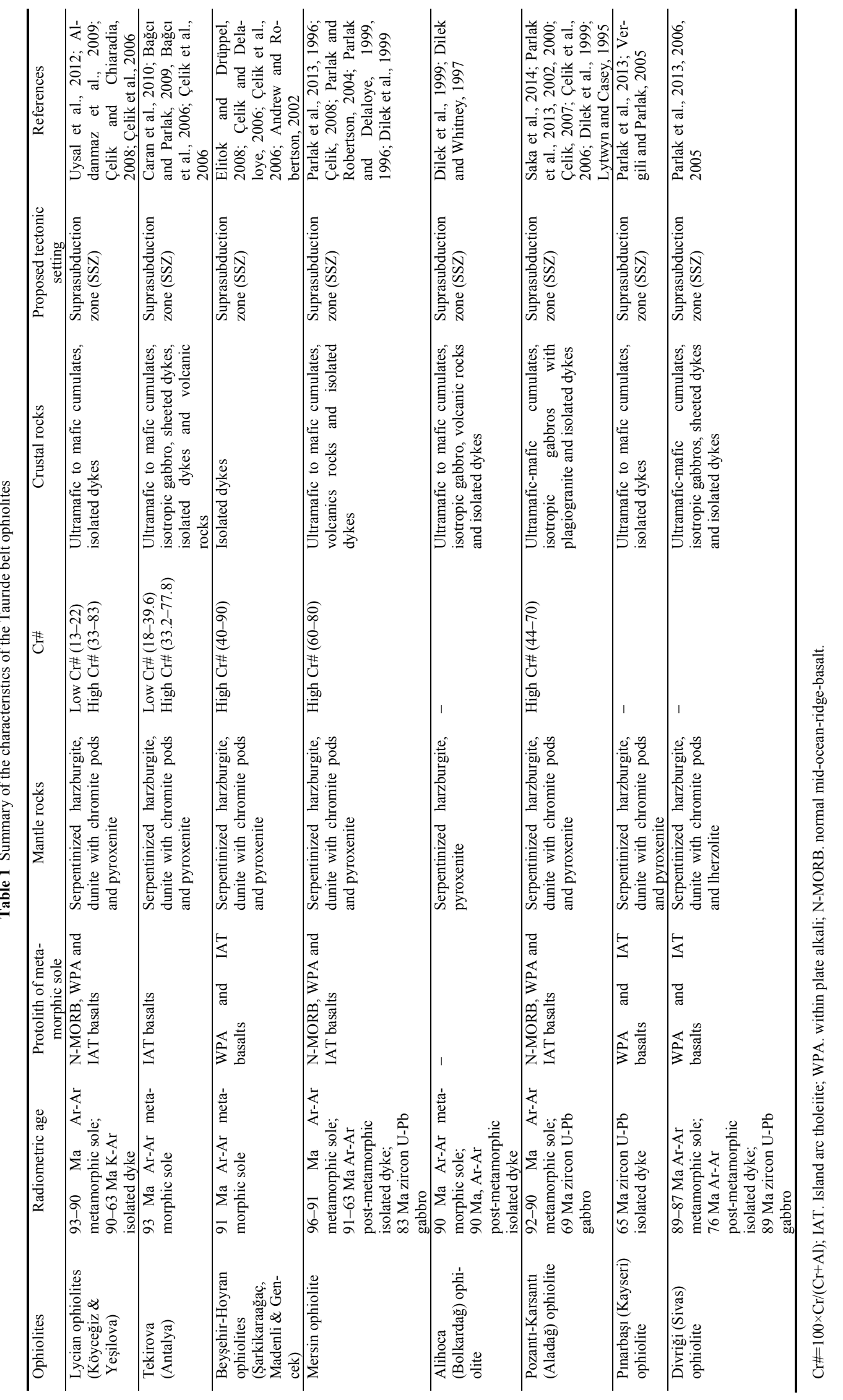




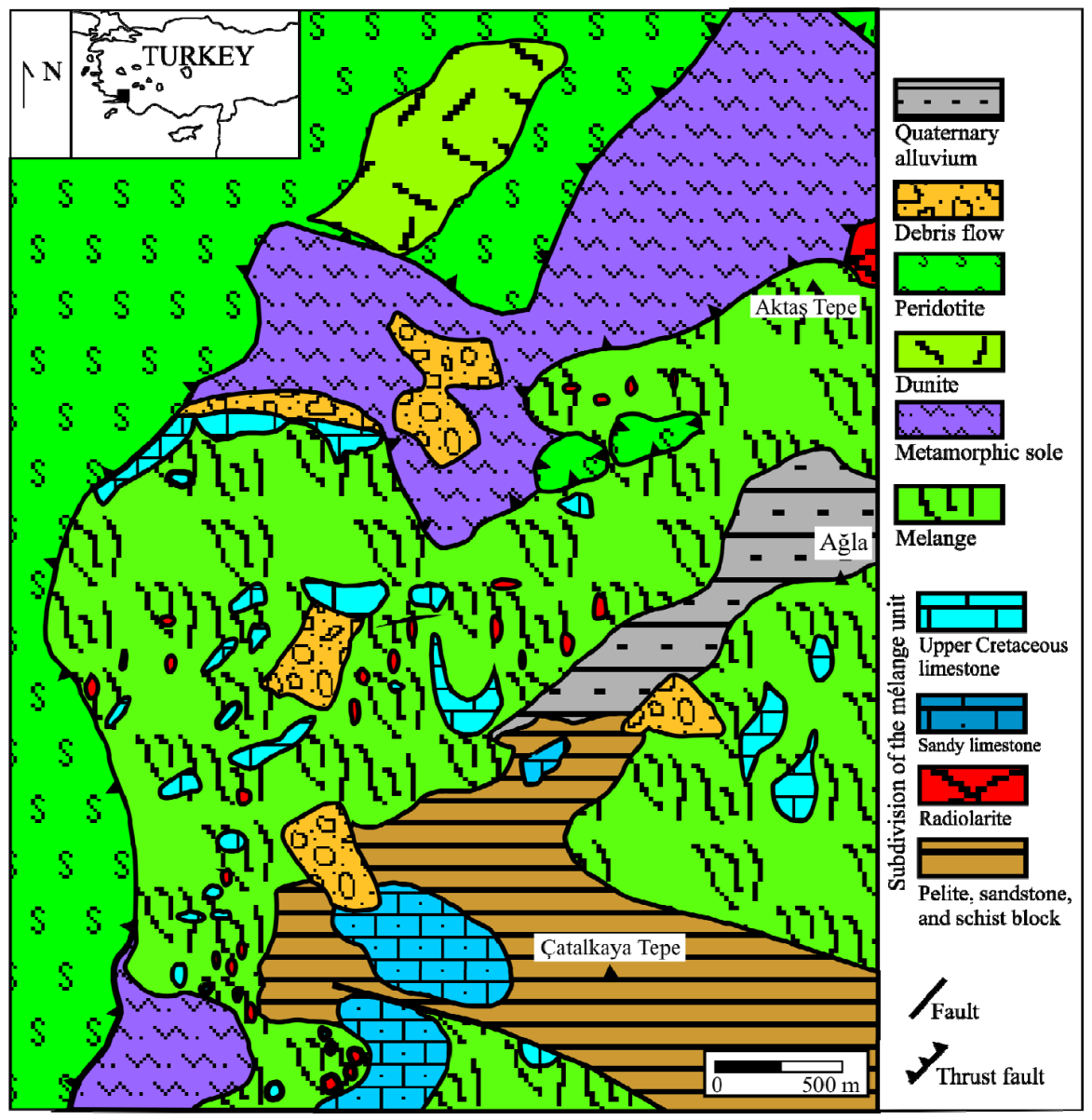

Figure 2. Geological map of the western part of the Lycian ophiolites in the Köyceğiz area (De Graciansky, 1972).

(Fig. 5a). It is composed of garnet amphibolite, amphibolite, plagioclase amphibolite, epidote amphibolite, epidosite, micaschist, calcschist and marble (Figs. 5c, 5d, $5 \mathrm{e})$. The metamorphic sole is highly deformed, folded and faulted, and up to $350 \mathrm{~m}$ thick (Çelik and Delaloye, 2003). Micaschists and calcschists are tectonically intercalated with amphibolites. Individual post-metamorphic dykes cut the metamorphic sole at different structural levels.

The Lycian ophiolites above the metamorphic sole consist exclusively of mantle tectonites enclosing enclaves of cumulates. The mantle tectonites predominantly comprise harzburgites (up to $95 \%$ ), dunites $(5 \%-10 \%)$ and pyroxenites $(\sim 1 \%)$ (Sarp, 1976). They are variably serpentinized and display plastic deformation indicated by alternations of harzburgite-pyroxenite-dunite-chromitite bands (Sarp, 1976). Orthopyroxenite, diallagite and websterite are rare in the mantle tectonites and occur either as discordant dykes or bands (Juteau, 1980; Sarp, 1976), usually exhibiting granoblastic and porphyroclastic textures. The cumulate enclaves in the tectonites consist of pyroxenite, olivine gabbro, gabbro, gabbronorite, anorthositic gabbro and anorthosite (Sarp, 1976). The whole peridotite body is crosscut at different structural levels by isolated dykes of gabbro and diabase with chilled margins (Fig. 4). A number of dykes in the severely serpantinized mantle tectonites have been affected by $\mathrm{Ca}$ metasomatism (rodingitization) (Sarp, 1976).

\subsubsection{Petrogenesis and geochronology of the Lycian ophiolites}

The mantle peridotites in the Köyceğiz (Muğla) area are composed of Cpx-bearing harzburgite, depleted harzburgite and dunite (Uysal et al., 2012; Aldanmaz et al., 2009). Uysal et al. (2012) reported that the Cpxharzburgites contain high $\mathrm{CaO}$ (2.27 wt.\%) and $\mathrm{Al}_{2} \mathrm{O}_{3}(2.07$ wt.\%) together with low $\mathrm{Cr}$ contents in coexisting spinels $(\mathrm{Cr} \#=100 \times \mathrm{Cr} /(\mathrm{Cr} / \mathrm{Al}): 13-22)$. In contrast, the depleted harzburgites and dunites have low $\mathrm{CaO}(0.58$ wt.\%) and $\mathrm{Al}_{2} \mathrm{O}_{3}(0.42$ wt.\%) with high-Cr spinels (Cr\#: 33-83). They concluded that the $\mathrm{Cpx}$-harzburgites were derived from the first-stage of melting and low-degrees of melt-rock interaction that occurred in a mid-ocean ridge (MOR) environment during the opening stage of the Neotethyan oceanic basin, but the depleted harzburgites and dunites were the products of second-stage melting and related refertilization in a suprasubduction zone (SSZ) environment. The geochemistry of the amphibolites from the metamorphic sole in Yeşilova area suggests that they are alkaline in character and exclusively derived from ocean island alkaline basalts (Çelik and Delaloye, 2003), while in contrast, the amphibolites from the metamorphic sole in the Köyceğiz area exhibit tholeiitic to alkaline magma types and were derived from mid-ocean ridge basalts (MORB), within plate basalts and island arc basalts (Çelik and Delaloye, 2003). The isolated diabase/dolerite dykes 


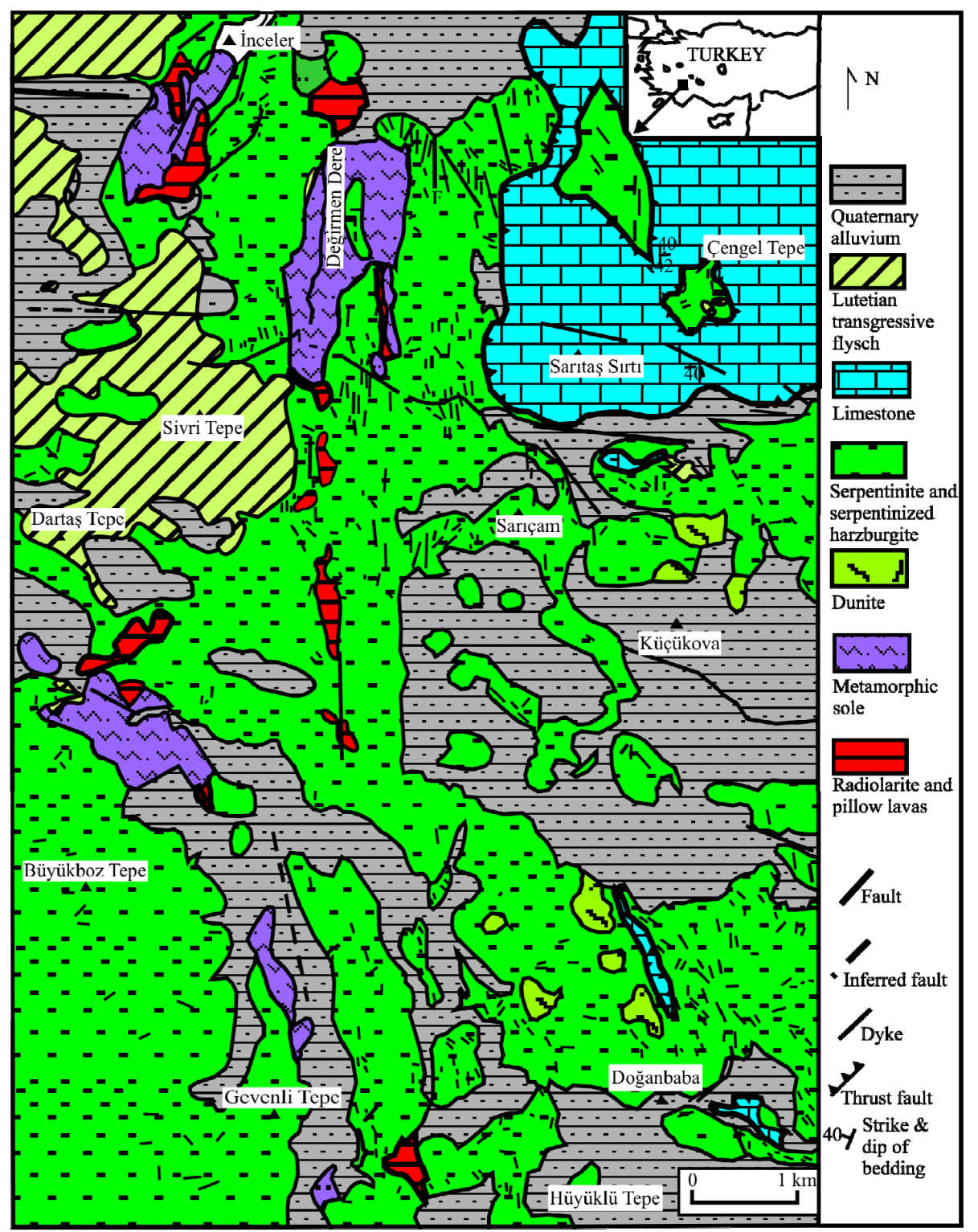

Figure 3. Geological map of the eastern part of the Lycian ophiolites in Yeşilova region (Sarp, 1976).

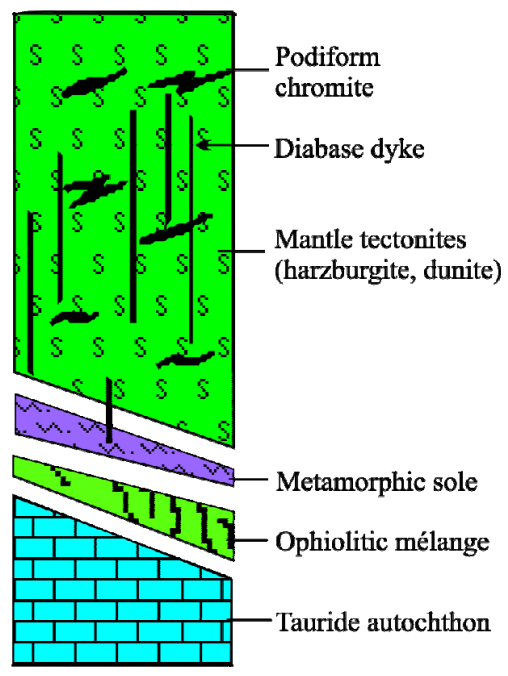

Figure 4. Tectonostratigraphy of the ophiolitic units in the Lycian ophiolites. intruding the metamorphic sole and mantle tectonites in the Köyceğiz (Muğla) and Yeşilova (Burdur) regions display pronounced $\mathrm{Nb}$-depletion, indicating a subduction-related setting for their magma genesis (Çelik and Delaloye, 2003). Pressure-temperature conditions $(P / T)$ under which the metamorphic sole rocks in the Köyceğiz and Yeşilova regions formed were $\sim 550{ }^{\circ} \mathrm{C} / \sim 5 \mathrm{kbar}$ and $\sim 600{ }^{\circ} \mathrm{C} / \sim 5 \mathrm{kbar}$, respectively (Çelik, 2002).

Thuizat et al. (1981) reported varied K-Ar ages for different mineral separates from three samples from the metamorphic sole at the base of the Lycian ophiolites. These are $102 \pm 4$ to $98 \pm 4 \mathrm{Ma}$ for hornblende separates, $88 \pm 4$ to $83 \pm 3$ Ma for plagioclase separates and $93 \pm 3$ Ma for muscovite separates (Thuizat et al., 1981). Çelik and Chiaradia (2008) also reported K-Ar ages ranging from 90 to $63 \mathrm{Ma}$ for the dyke intrusions in the Yeşilova region. The new ${ }^{40} \mathrm{Ar} /{ }^{39} \mathrm{Ar}$ ages for the metamorphic sole rocks beneath the Lycian ophiolites (Köyceğiz and Yeşilova) tightly constrain the timing of intraoceanic thrusting as Late 


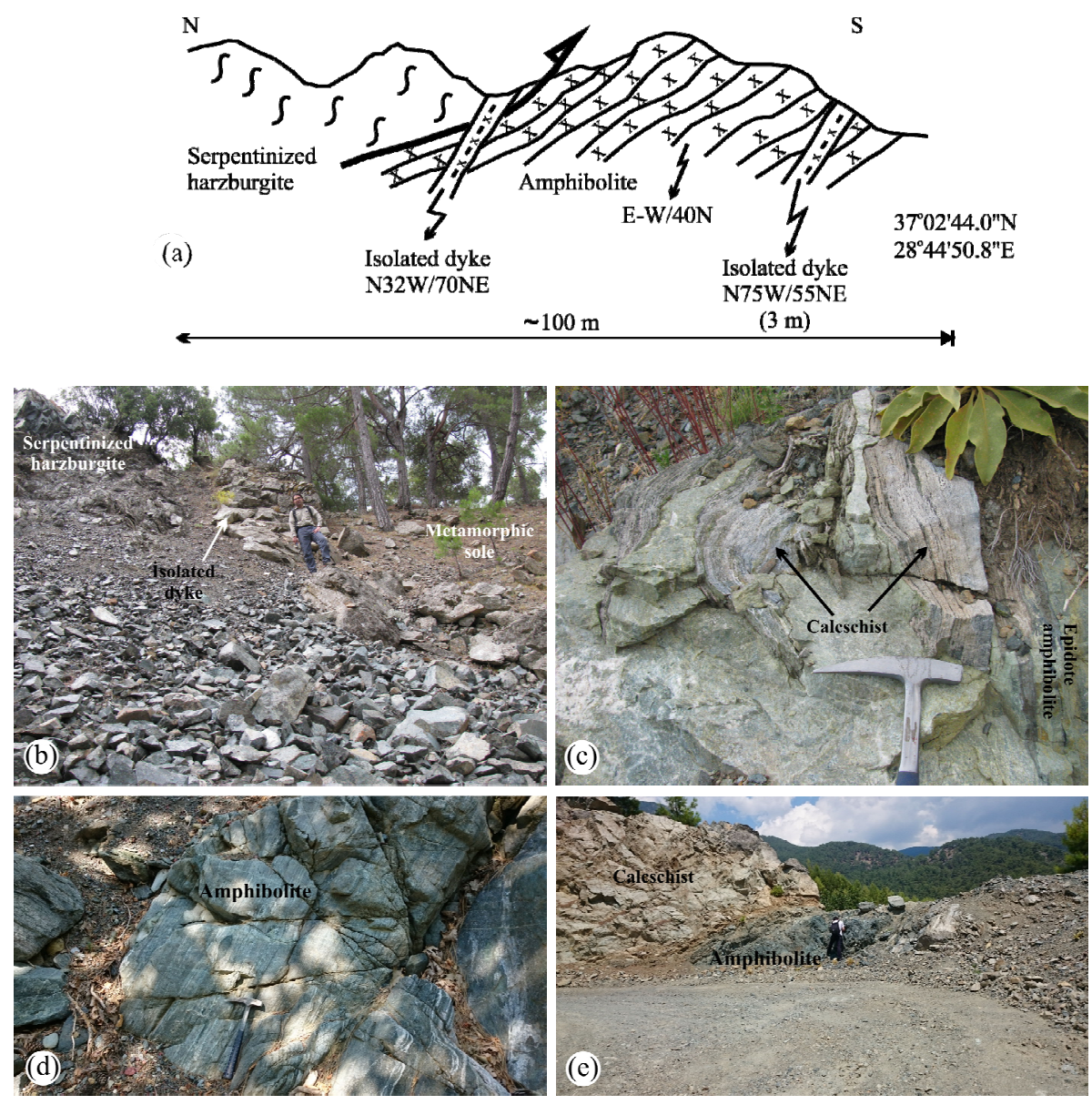

Figure 5. (a) Cross section showing the field relations of mantle tectonites and their underlying metamorphic sole in the Köyceğiz area. Field views of (b) the isolated dyke cutting the intraoceanic decoupling surface between mantle peridotite and the metamorphic sole, (c) deformed alternations of calcschist and epidote-amphibolite, (d) foliated amphibolites, and (e) calcschist and amphibolite.

Cretaceous (Çelik et al., 2006). Hornblende separates of the amphibolites in the Köyceğiz area yielded ages of $93.1 \pm 0.9$ to $93.0 \pm 0.9 \mathrm{Ma}$, similar to the white mica ages $(93.6 \pm 0.8$ to $91.7 \pm 0.7 \mathrm{Ma})$. The hornblende separates of the amphibolites in the Yeşilova area yielded $91.3 \pm 0.9$ to $90.7 \pm 0.5$ Ma ages and white mica yielded an age of $91.2 \pm 2.3 \mathrm{Ma}$ (Çelik et al., 2006). The age dating in both areas indicates a rapid cooling history.

\subsection{Tekirova (Antalya) Ophiolite}

The Antalya complex in Southwest Turkey comprises a number of autochthonous (the Beydağları Platform) and allochthonous (e.g., Kumluca unit, Alakırçay mélange, Tekeli-Tahtalı Dağ unit and Tekirova ophiolite) sedimentary, magmatic and metamorphic rock assemblages, that originated from oceanic, oceanic to continental margin and continental settings (Y1lmaz, 1984; Robertson and Woodcock, 1981a, b, c, 1980; Delaune-Mayere et al., 1977; Marcoux, 1976; Juteau, 1975; Brunn et al., 1971, 1970). The allochthonous units of the Antalya complex were emplaced onto the Mesozoic Beydağları Platform during the Late Cretaceous (Fig. 6).

The Tekirova ophiolite comprises, from bottom to top, mantle tectonites, ultramafic-mafic cumulates, isotropic gabbros, sheeted dykes, plagiogranite, mafic volcanic rocks and associated sediments (Fig. 7). Contacts between these units are tectonic. The mantle tectonites, ultramafic to mafic cumulates and isotropic gabbros are intruded by isolated diabase dykes (Fig. 7). Metamorphic sole rocks in Tekirova ophiolite are observed as isolated blocks.Mantle tectonites are observed in Adrasan, Çıralı, and Kemer as well as in an $\mathrm{N}-\mathrm{S}$ trending tectonic zone between the Kumluca and Doyran regions (Fig. 6). The mantle tectonites display porphyroclastic to mylonitic textures and are predominantly harzburgites $(>80 \%)$ with lesser amounts of dunite, orthopyroxenite, and chromitite (Juteau et al., 1977). Although the mantle tectonites are variably serpentinized they present good foliation patterns in the field defined by spinel and orthopyroxene aspect ratios (Juteau et al., 1977). Dunites with chromite pods are common and penetratively deformed. The harzburgitic tectonites also include veinlets of pyroxenite and two-pyroxene gabbro (Juteau et al., 1977). Irregular lenses of gabbro and clinopyroxenite due to rockmelt interaction in the harzburgitic mantle are also present. The well-preserved ultramafic to mafic cumulate rocks in the Tekirova ophiolites crop out mainly along the coastal section at Çıral1-Tekirova and at Doyran to the north. Small outcrops of mafic cumulate rocks are tectonically dispersed in places such as Gödene, Kuzdere, Kemer, Kuvvettaş Dere and Ziyaret Tepe within the Gödene zone (Fig. 6). The 
undeformed ultramafic to mafic cumulates in the ÇıralıTekirova section are strongly layered and exhibit structures such as slumping, cross-bedding, phase and mineral ratio layering and mineral graded layers indicative of cumulate processes in a magma chamber (Bağc1 et al., 2006; Juteau et al., 1977). They consist of dunite, clinopyroxenite, and wehrlite at the base, followed upwards by olivine gabbro, olivine gabbronorite and gabbro at the top. Four magmatic cycles were recognized with a total thickness of 3 to $4 \mathrm{~km}$ (Juteau and Whitechurch, 1980; Juteau et al., 1977). The dunite layers at the bottom also contain chromitite bands (Juteau et al., 1977). The isotropic gabbros crop out in the Kuzdere and Kemer regions (Fig. 6) and are represented by gabbro, diorite and quartz diorite. Small-scale plagiogranitic intrusions cut the isotropic gabbros at the Kemer junction. The mantle tectonites, ultramafic to mafic cumulates and isotropic gabbros are intruded by isolated dykes. Sheeted dykes are exposed locally north of Kemer and represented by panels of more or less brecciated diabase dykes, hosted by isotropic gabbros (Juteau, 1975). Volcanic rocks of the ophiolite suite are observed within the Gödene zone. Pelagic chalks interbedded with the volcanic rocks yielded a Late Cretaceous age (Robertson and Woodcock, 1982). A volcanic unit composed of mafic pillow lava interbedded with Late Triassic and Late Jurassic-Early Cretaceous pelagic sediments of the Alakırçay mélange is present (Robertson and Waldron, 1990; Marcoux, 1970).

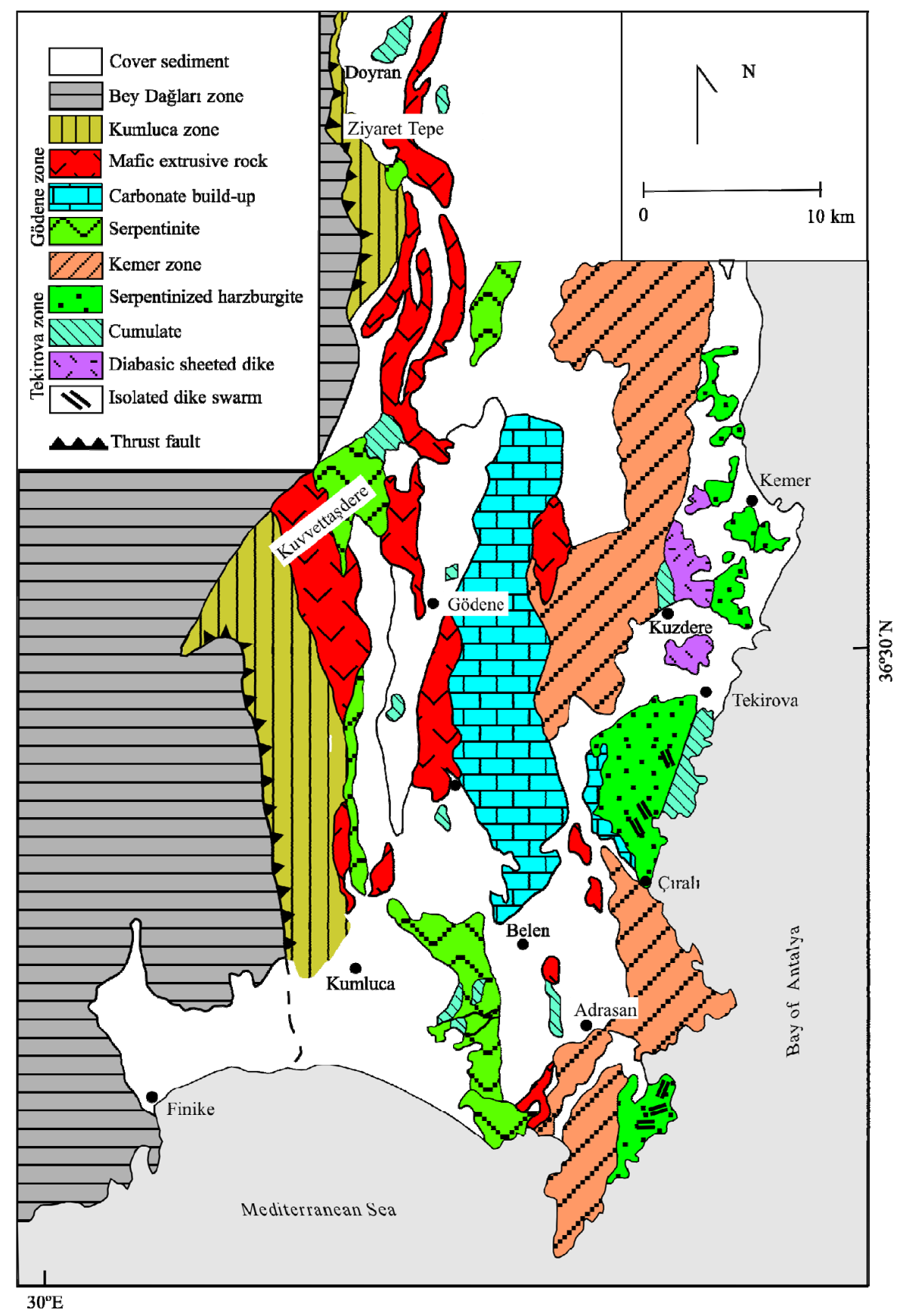

Figure 6. Geological map of the Tekirova (Antalya) ophiolite (Juteau and Whitechurch, 1980). 

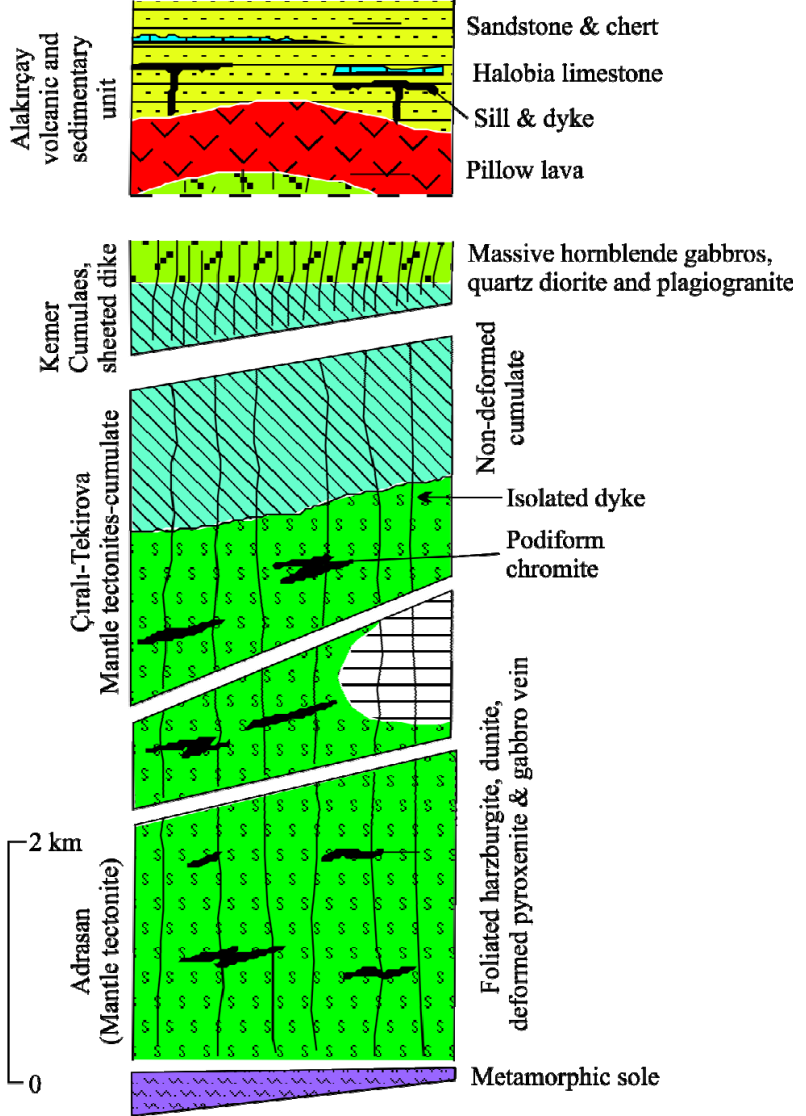

Figure 7. Reconstructed column section of the Tekirova (Antalya) ophiolite (Juteau, 1975)

\subsubsection{Petrogenesis and geochronology of the Tekirova (Antalya) ophiolite}

Geochemical data for the mantle peridotites of the Tekirova ophiolite exhibit a fertile to ultra-refractory character reflected by a progressive decrease in bulk rock contents of $\mathrm{Al}_{2} \mathrm{O}_{3}, \mathrm{CaO}, \mathrm{SiO}_{2}, \mathrm{TiO}_{2}, \mathrm{Sc}, \mathrm{V}, \mathrm{Y}$ and an increase in magnesium numbers $\left(\mathrm{Mg} \#=100 \times \mathrm{Mg} /\left(\mathrm{Mg}^{2} \mathrm{Fe}^{+2}\right)\right)$ and spinel chromium numbers (Cr\#: 18.0-39.6 in spinel lherzolites, 33.2-77.8 in harzburgites, and 68.7-72.2 in dunites) (Caran et al., 2010). The chondrite-normalized REE patterns of the spinel lherzolites are compatible with a residue of a low degree of partial melting of N-MOR mantle (Caran et al., 2010) the harzburgites although show 'V-shaped' REE distribution patterns similar to those of forearc harzburgites. The harzburgites could be residues from interaction of a previously melted mantle source with an ascending LREE-enriched melt in a suprasubduction zone environment. The dunites and the most refractory peridotites formed by dissolution of pyroxene from the host harzburgites during melt-mantle interaction (Caran et al., 2010). The podiform chromitites are composed of a very refractory olivine-spinel assemblage (Fo: 94.8 and 96.1 and Cr\#: 72.2-81.2), suggesting formation from a boninitic magma (Caran et al., 2010). The ultramafic and mafic cumulate rocks in the Tekirova ophiolite are wehrlite, lherzolite, olivine clinopyroxenite, olivine gabbronorite, olivine gabbro, gabbronorite and gabbro (Bağc1 et al., 2006). The order of crystallization in the cumulates is olivine
$\left(\mathrm{Fo}_{88-76}\right) \pm$ chromian $\quad$ spinel \pm clinopyroxene $\quad\left(\mathrm{Mg}_{92-76}\right) \pm$ orthopyroxene $\left(\mathrm{Mg} \#_{86-70}\right) \pm$ plagioclase $\left(\mathrm{An}_{97-84}\right)$. The whole-rock mineral chemistry, crystallization order of mineral phases, and high-An content of plagioclase in the cumulate rocks indicate that the Tekirova (Antalya) ophiolite formed in a suprasubduction zone environment (Bağc1 et al., 2006). Limited cryptic variation through the cumulate rocks of the Tekirova ophiolite suggests that they crystallized from a compositionally uniform magma (Bağc1 et al., 2006). The isotropic gabbros and the isolated dykes cutting the mantle tectonites and the crustal rocks exhibit tholeiitic to alkaline compositions. Three main types of parental basic magmas formed the oceanic crustal rocks of the Tekirova (Antalya) ophiolite: (1) island arc tholeiites (IAT), (2) low-Ti boninites and (3) ocean island basalts (OIB) (Bağcı and Parlak, 2009). The geochemical evidence suggests that the crustal rocks of the Tekirova (Antalya) ophiolite were generated by progressive source depletion from island arc tholeiites (IAT) to boninites and therefore, a fore-arc tectonic setting seems likely for the generation of the crustal rocks (Bağc1 and Parlak, 2009). The OIB-type alkaline isotropic gabbros are thought to have resulted from either; (1) late-stage magmatic activity fed by melts that originated from an asthenospheric window created by slab break-off or (2) subduction of a ridge system which generated an OIB source across the asthenospheric window (Bağcı and Parlak, 2009). Robertson and Waldron (1990) reported occurences of Late Triassic and Late JurassicEarly Cretaceous basaltic extrusives in the Antalya complex. The Late Triassic lavas are associated with radiolarites, pelagic limestones, turbidites and patch reefs, and range from within plate to transitional and MORB-type basalts (Robertson and Waldron, 1990) whereas the Late JurassicEarly Cretaceous basalts exhibit a MORB-type geochemical character and may reflect renewed spreading within a preexisting Antalya ocean basin (Robertson and Waldron, 1990).

The magmatic and the metamorphic rocks associated with the Tekirova (Antalya) ophiolites have been dated by $\mathrm{K}-\mathrm{Ar}$ and ${ }^{40} \mathrm{Ar} /{ }^{39} \mathrm{Ar}$ geochronology. The magmatic rocks (gabbro, diabase, plagiogranite) and the metamorphic rocks from the Alakırçay mélange as well as the Tekirova ophiolite yielded very scattered (130 to $60 \mathrm{Ma}) \mathrm{K}-\mathrm{Ar}$ cooling ages (Y1lmaz, 1984). Thuizat et al. (1981) reported $94 \pm 4$ Ma hornblende and 102 \pm 7 Ma plagioclase K-Ar ages for garnet amphibolites from the metamorphic sole in the Antalya complex. Recent ${ }^{40} \mathrm{Ar} /{ }^{39} \mathrm{Ar}$ dating of hornblende separates from the metamorphic sole within the Alakırçay mélange have yielded more reliable Late Cretaceous ages (93.8 \pm 1.7 and 93.0 $\pm 1.0 \mathrm{Ma}$ ) (Çelik et al., 2006).

\subsection{Beyş̧ehir-Hoyran Ophiolite}

The Beyşehir-Hoyran Nappes include Mesozoic carbonate platform deposits, deep sea sediments and ophiolite-related units (ophiolitic mélange, metamorphic sole and ophiolite) and crop out extensively on the western limb of the Isparta Angle of the central Taurides (Andrew and Robertson, 2002; Özgül, 1984; Monod, 1977; Özgül and 
Arpat, 1973). The ophiolite-related rock assemblages are well exposed both to the north and south of Lake Beyşehir (Fig. 1).

In the northern part of the Lake Beyşehir area, the ophiolitic rocks are seen at two localities, namely Madenli and Şarkikaraağaç (Figs. 8, 9). The ophiolitic rocks in the Şarkikaraağaç area tectonically overlie the Anamas-Akseki Platform in the west and Sultandağ Platform in the east. The contact relations between the two sides are not clear because the area is covered by Neogene sediments (Fig. 8). On the Anamasdağ side, the ophiolite-related rocks are represented by harzburgitic mantle tectonites at the top, underlain downwards by a subophiolitic metamorphic sole and mélange (Fig. 10). The harzburgites exhibit mediumgrained granoblastic texture and are characterized by forsteritic olivine $\left(\mathrm{Mg \#}_{92-93}\right)$, orthopyroxene and minor chromian spinel and diplay mylonitic textures at the basal thrust contact (Elitok and Drüppel, 2008). Isolated diabase dykes intrude the mantle tectonites. A thin sheet of highlydeformed metamorphic sole rocks, up to $140 \mathrm{~m}$ thick, tectonically underlies the harzburgitic mantle tectonites (Elitok and Drüppel, 2008). These rocks directly beneath the mantle tectonites mainly exhibit granoblastic to nematoblastic textures and are composed of pyroxene amphibolite and amphibolite, followed by epidote amphibolite, plagioclase amphibolite, calcschist and quartzite towards the bottom (Elitok and Drüppel, 2008). The metamorphic sole is cut by isolated post-metamorphic diabase dykes as in the other Tauride ophiolites. On the Sultandağ side, relatively fresh harzburgitic mantle tectonites with minor pyroxenite veins rest tectonically on an ophiolitic mélange. The harzburgites are intruded by isolated diabase dykes at different structural levels (Elitok
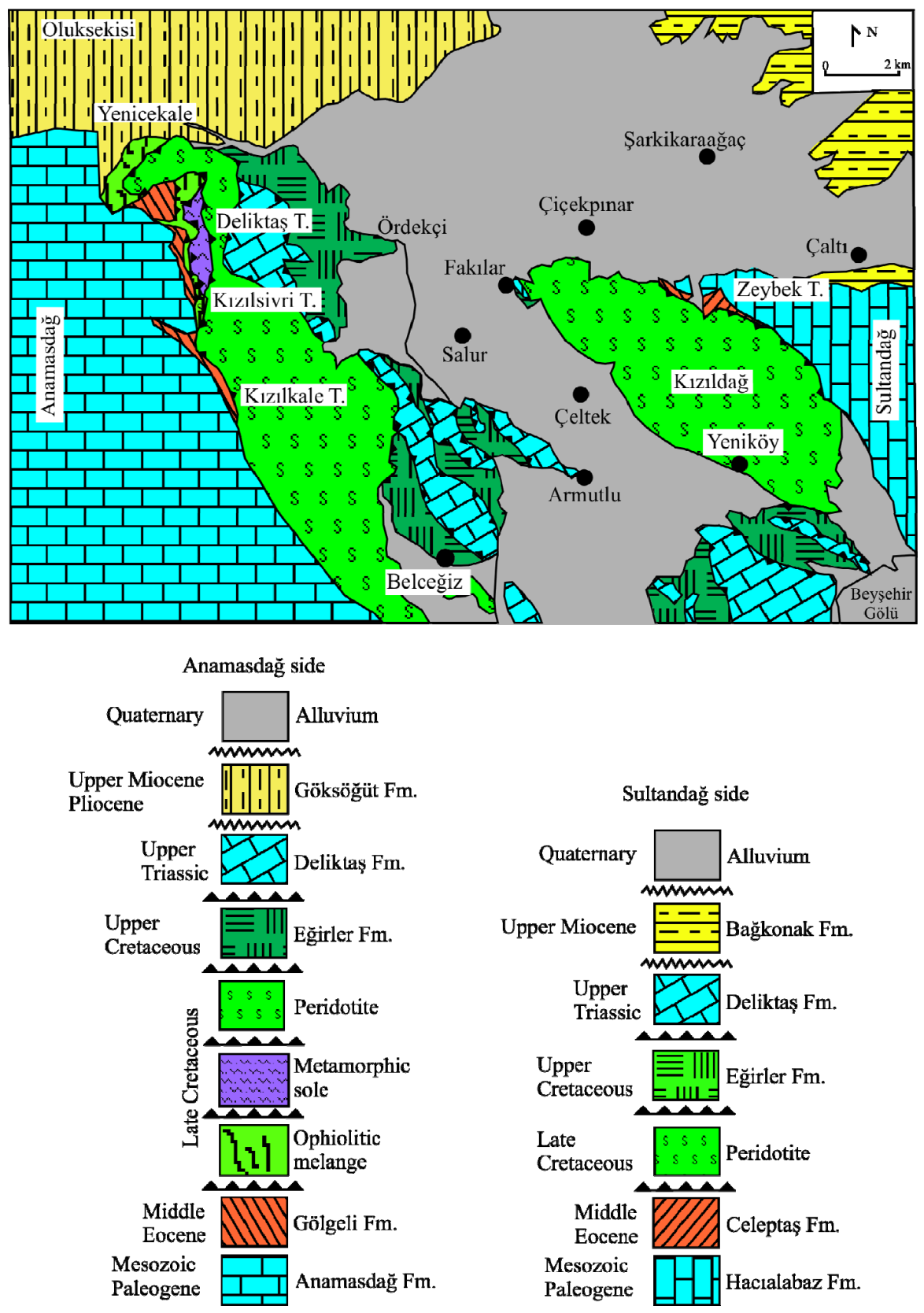

Figure 8. Geological map of the Şarkikaraağaç area (Elitok and Drüppel, 2008). 


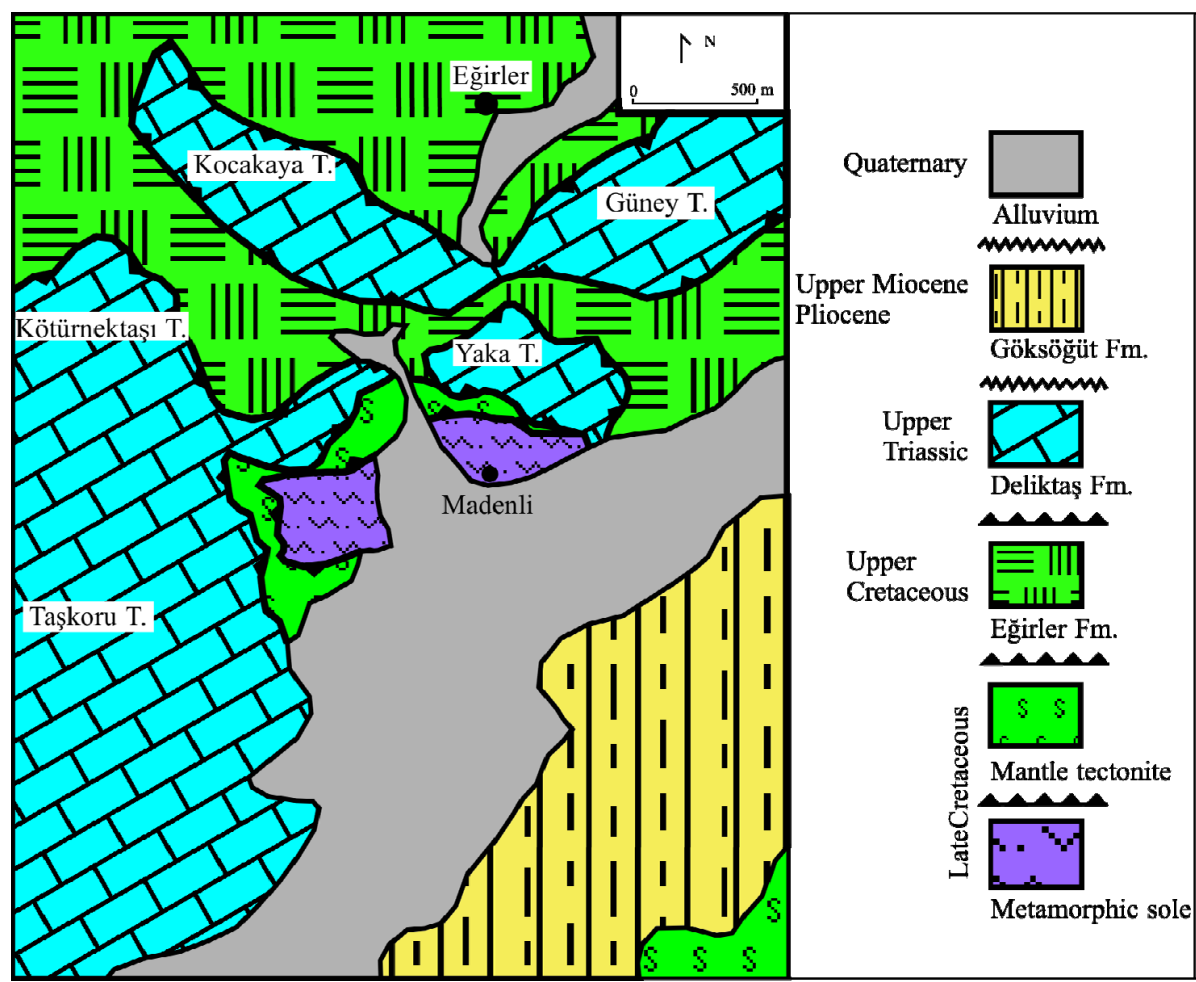

Figure 9. Geological map of the Madenli area (Elitok and Drüppel, 2008).

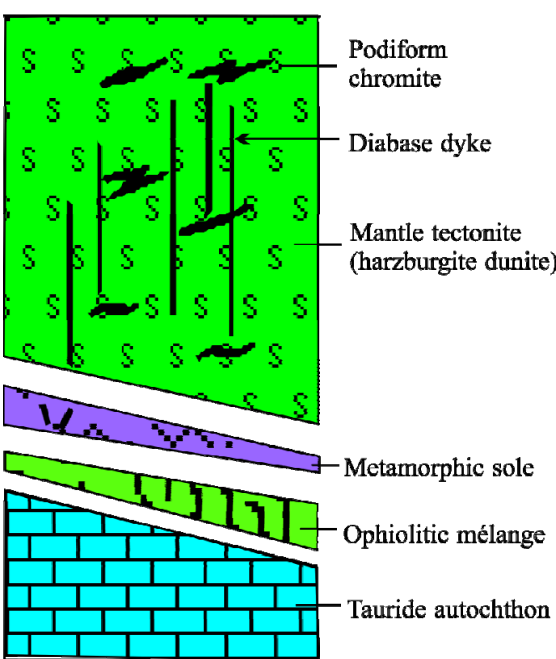

Figure 10. Tectonostratigraphy of the ophiolitic units in the northern part of the Beyşehir lake.

and Drüppel, 2008). In both regions, the ophiolites are tectonically underlain by ophiolitic mélanges that contain blocks of recrystallized limestone, gabbro, isolated diabase, radiolarite, cherts, and silicaclastic rocks set in a strongly sheared serpentinite matrix (Elitok and Drüppel, 2008). The ophiolite-related units in both areas are overthrust by Upper Triassic massive neritic limestones and wildflysch deposits. The limestone unit in the Central Taurides is known as the Gencek unit (Monod, 1977) or Boyalı Tepe unit (Andrew and Robertson, 2002). Both the Gencek and the Boyal1 Tepe units consist of blocks and dismembered thrust sheets in a sandy wildflysch matrix (Andrew and Robertson, 2002). Allochthonous units, namely metamorphic sole rocks,
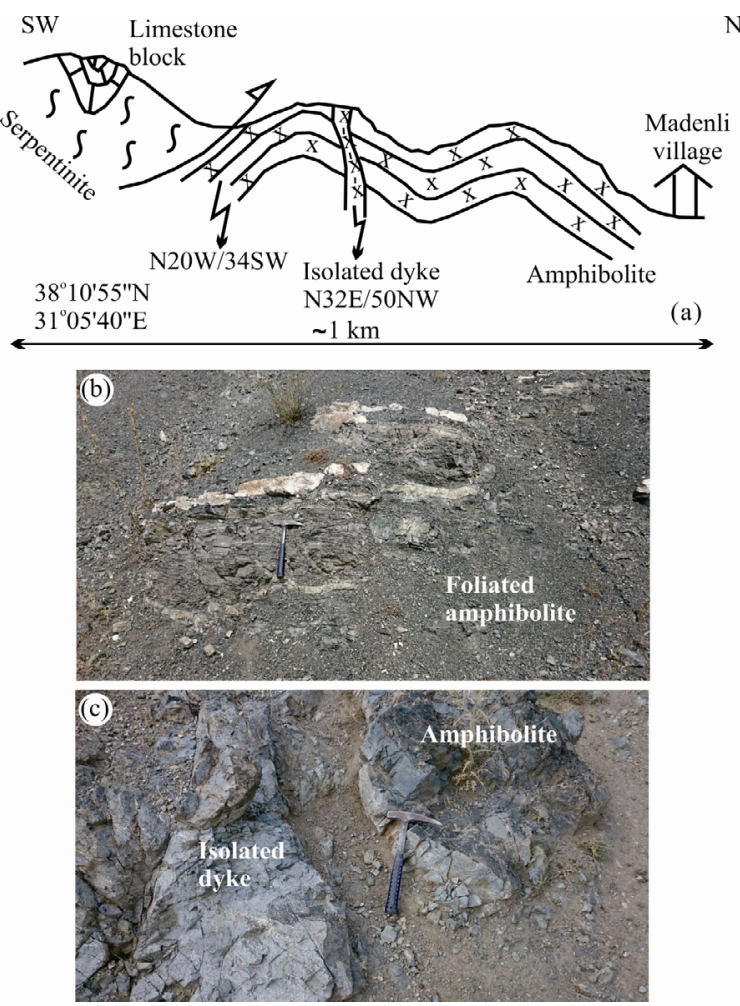

Figure 11. (a) Cross section showing the field relations of the mantle tectonites, underlying metamorphic sole and the limestone thrust sheet in Madenli area. Field views of (b) the foliated amphibolite and (c) isolated dyke in the metamorphic sole in Madenli.

mantle tectonites, the Gencek unit and wildflysch are exposed In the Madenli area (Fig. 9). The metamorphic sole rocks beneath the mantle tectonites are highly deformed and 
characterized by amphibolites and epidote amphibolites and are intruded by isolated diabase dykes (Figs. 11a, 11b, 11c). The strongly sheared serpentinized harzburgites rest tectonically on the metamorphic sole and are followed upward by thrust slices of Upper Triassic massive neritic limestones (Fig. 11a) of the Gencek or Boyal1 Tepe units and wildflysch deposits (Andrew and Robertson, 2002; Monod, 1977), as in the Şarkikaraağaç area.

In the southern part of the Lake Beyşehir area, the ophiolite-related rock assemblages are exposed as thrust slices between the Hadim nappe and the Gencek unit around Gencek Village (Figs. 12, 13). The ophiolitic

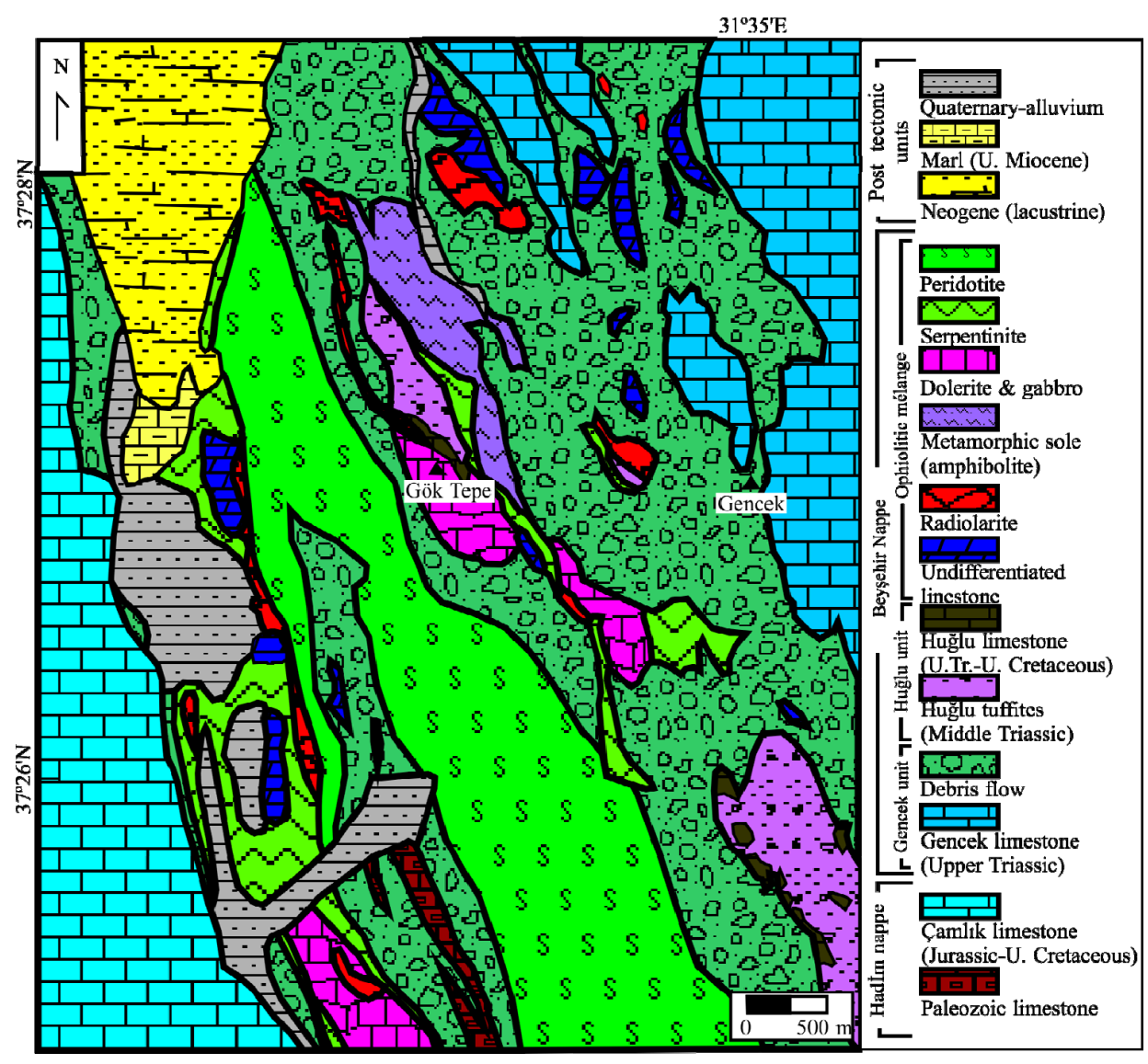

Figure 12. Geological map of the Gencek region south of Beyşehir Lake (Monod, 1977).
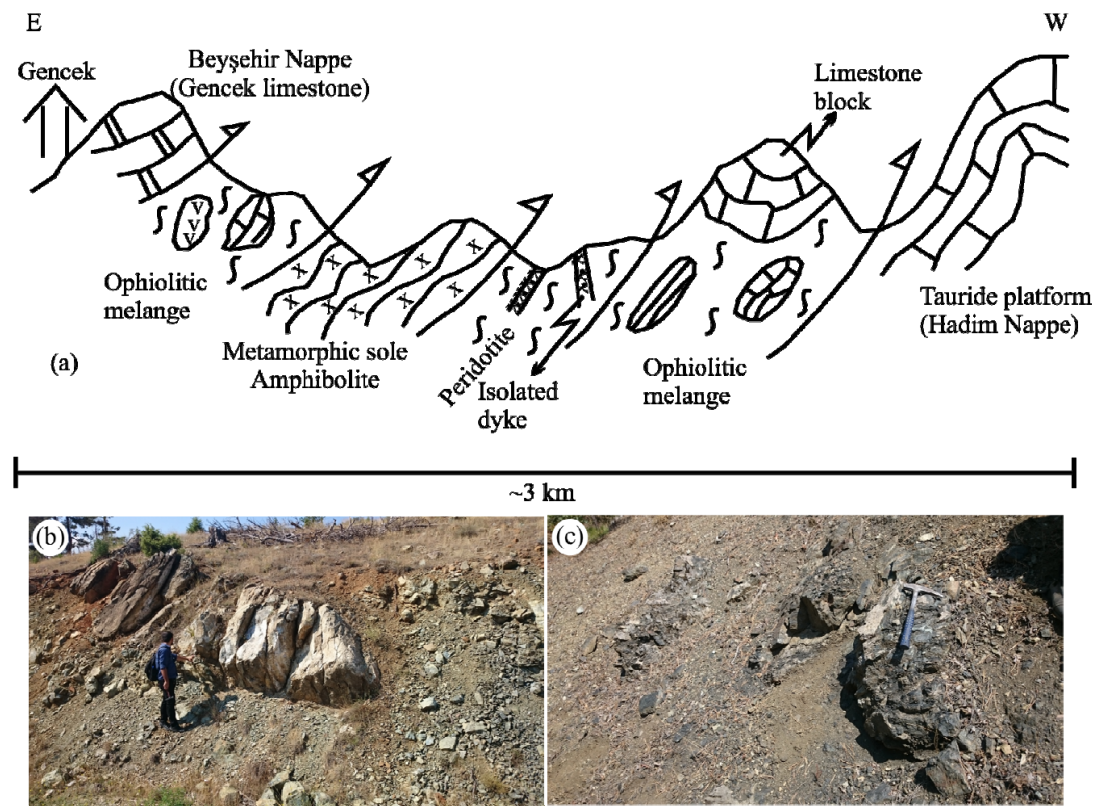

Figure 13. (a) Cross section showing the field relations of the tectonic units to the west of Gencek Village. Field views of (b) an isolated dyke cutting mantle peridotite and (c) foliated amphibolite from the metamorphic sole in the Gencek area. 
mélange unit consists mainly of blocks and fragments of radiolarian cherts, serpentinite, limestone, volcanic rocks, volcaniclastic sediments, serpentinized peridotite, and amphibolites set in a sandstone and mudstone matrix (Andrew and Robertson, 2002). The age of the units within the mélange ranges from Triassic to Upper Cretaceous. The metamorphic sole rocks exhibit granoblastic to nematoblastic textures and are represented by garnet amphibolite, pyroxene amphibolite, plagioclase amphibolite and epidote amphibolite (Fig. 13c) (Çelik and Delaloye, 2006). A peridotite body in the mélange is represented by serpentinized harzburgite and intruded by numerous isolated diabase dykes (Figs. 13a, 13b).

\subsubsection{Petrogenesis and geochronology of the Beyşehir- Hoyran ophiolite}

Whole rock geochemistry of fresh peridotites (mainly harzburgite) in the Beyşehir-Hoyran ophiolite reveals $\mathrm{Cr}$ and Ti contents akin to those inferred to be suprasubduction zone ophiolites (Andrew and Robertson, 2002). High chromium numbers (Cr\#: 40-90) confirm their SSZ origin. Whole rock analyses of the isolated dykes cutting the peridotites also suggest a subduction related setting because they show marked Nb-depletion when normalized to $\mathrm{N}$ MORB (Andrew and Robertson, 2002). Elitok and Drüppel (2008) reported that the dykes cutting the peridotites and the metamorphic sole in Şarkikaraağaç area exhibit depleted- to enriched-LREE geochemistry, also suggesting a subduction-related setting for their genesis. The amphibolites from the metamorphic sole of the Gencek area of the Beyşehir-Hoyran ophiolites to the south of Beyşehir Lake have alkaline to subalkaline compositions (Çelik and Delaloye, 2006). Trace element geochemistry suggests that they were derived from within plate alkaline basalt (WPA). In contrast the amphibolites from the metamorphic sole of the Şarkikaraağaç area of the Beyşehir-Hoyran ophiolites to the north of Beyşehir Lake display two different geochemical affinities, namely alkaline and tholeiitic. Their trace element geochemistry suggests derivation from within-plate alkali basalts and tholeiitic island arc basalts (Elitok and Drüppel, 2008). The pressure-temperature conditions $(P / T)$ under which the metamorphic sole rocks in Gencek area formed were $550-600{ }^{\circ} \mathrm{C}$ and $\sim 5$ kbar (Çelik and Delaloye, 2006).

The first geochronological study on the amphibolites of the metamorphic sole rocks from the Beyşehir-Hoyran ophiolite by K-Ar yielded cooling ages of $93 \pm 3$ Ma for hornblende and $84 \pm 3$ Ma for plagioclase separates (Thuizat et al., 1981). More precise ${ }^{40} \mathrm{Ar} /{ }^{39} \mathrm{Ar}$ cooling ages of $91.5 \pm 1.9$ to $90.9 \pm 1.3$ Ma were obtained by Çelik et al. (2006).

\subsection{Mersin Ophiolite}

The Mersin ophiolite is located in the southern flank of the Tauride calcareous axis in southern Turkey and offset from the Pozantı-Karsantı ophiolite by the sinistral Ecemiş fault (Fig. 14) (Juteau, 1980). The overall tectonostratigraphy, from bottom to top, is: (1) Mersin mélange, (2) metamorphic sole, and (3) Mersin ophiolite (Fig. 15)
(Parlak, 1996; Pampal, 1987, 1984).

The Mersin mélange is exposed along an SW-NE trending tectonic zone at the top of the Tauride Platform and has an exposure area of around $600 \mathrm{~m}^{2}$ (Parlak and Robertson, 2004). It directly overlies Upper Cretaceous pelagic carbonates (the Yavça Formation) that form the highest stratigraphic levels of the Tauride carbonate platform. The Mersin mélange unit consists of both variable-sized blocks of limestone and locally coherent stratigraphic successions tens to hundreds of meters thick that have been interpreted as parts of broken formations. They mainly strike NE-SW and dip southward beneath the Mersin ophiolite (Fig. 15) (Parlak and Robertson, 2004). The tectonic contact between the mélange and the ophiolite dips towards N70E/71SE in the Sorgun valley. Four distinct assemblages are documented, namely; (1) a shallow-water carbonate association, ranging in age from Permian to Late Cretaceous; (2) a volcanogenic-terrigenous-pelagic association, ranging in age from Late Triassic to Late Cretaceous; (3) a seamount type alkaline basalt-radiolaritepelagic limestone association, ranging in age from Upper Jurassic-Lower Cretaceous and (4) an ophiolite-derived association of Late Cretaceous Age (Parlak and Robertson, 2004). The matrix of the mélange formed by a combination of tectonic and sedimentary processes during latest Cretaceous time (Parlak and Robertson, 2004). As a whole, the Mersin mélange documents a number of events including Triassic rifting of the Tauride continent, JurassicCretaceous passive margin subsidence, oceanic seamount genesis, and Cretaceous oceanic crust genesis (Parlak and Robertson, 2004).

The Mersin mélange is structurally overlain by the Mersin ophiolite, with a preserved metamorphic sole at three localities (Fig. 15). Thin units of ophiolite-related metamorphic rocks at three localities occupy a constant stratigraphic position at the base of a thick ultramafic unit (Fig. 15). At Findıkpınarı Village, the metamorphic rocks crop out between the hazburgitic tectonite and the mélange unit. The metamorphic sole rocks display granoblastic to nematoblastic textures and are represented by amphibolites, amphibole schists, epidote-amphibole schists, quartz-epidoteamphibole schists, quartzites and marble lenses. Foliation surfaces in the metamorphic sole generally strike NE and dip variably toward the SW. The structural thickness of the metamorphic sole is $\sim 200-250 \mathrm{~m}$. The rocks are folded, imbricated and cut by post-metamorphic diabase dykes (Figs. 16a, 16c) with thicknesses ranging from 0.4 to $4 \mathrm{~m}$ whose attitudes vary from N60E to E-W. The dykes do not intrude the tectonic contact with the overlying harzburgite in a similar manner to the Pozant1-Karsant1 and Lycian ophiolites, suggesting that some primary features were obliterated due to intensive deformation. The metamorphic sole rocks rest tectonically on the volcanic (pillow lava) and sedimentary (pelagic limestone, mudstone and manganese-rich cherts) rock assemblages of the mélange unit. The second outcrop of the metamorphic sole crops out at the base of the serpentinized mantle tectonites in a deep valley at Şahna Village where there are ductily deformed and folded 


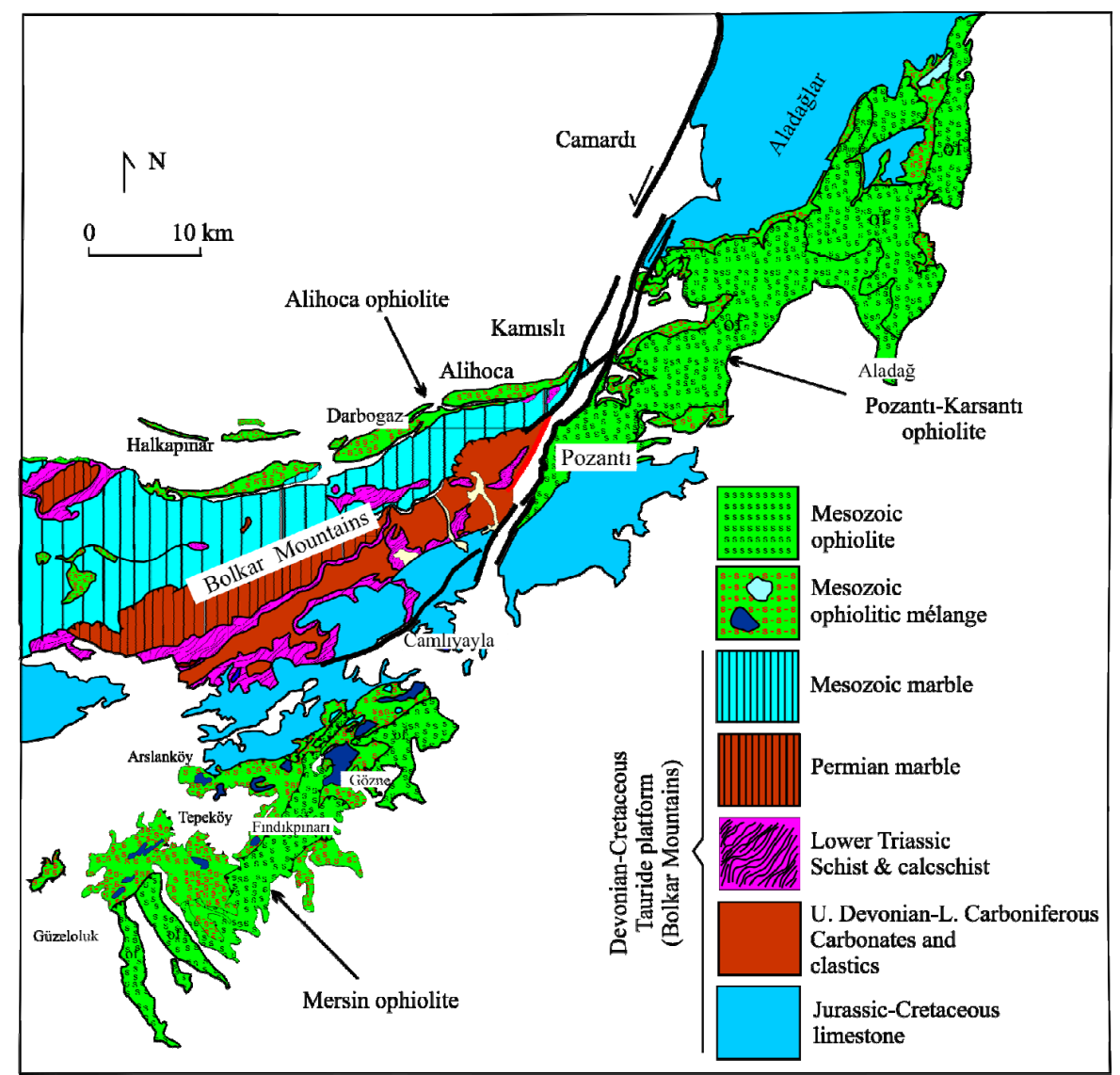

Figure 14. Simplified geological map of the Bolkardağ region, showing the relationships of the Mersin, Alihoca and Pozantı-Karsant1 ophiolites (MTA, 2002).
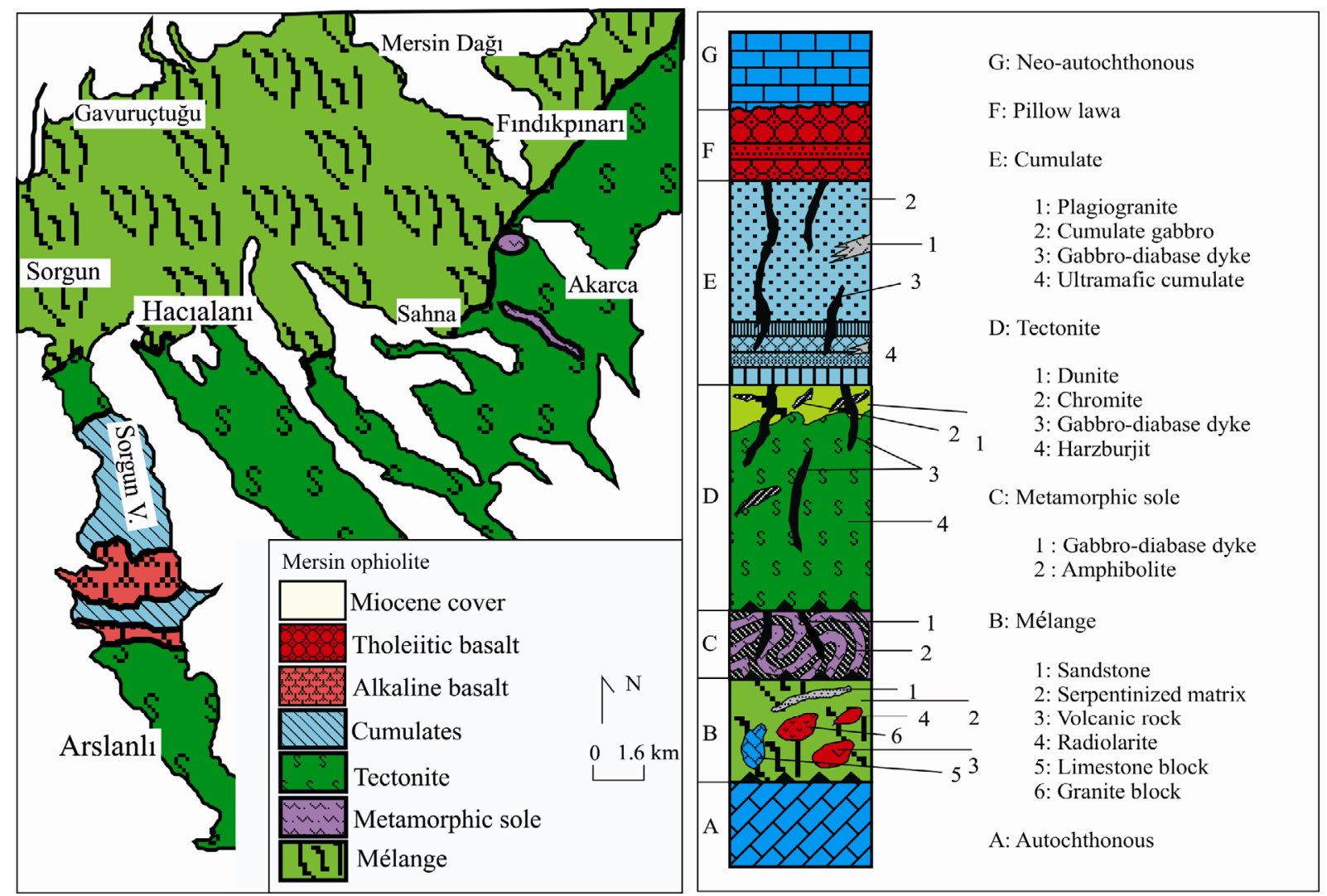

Figure 15. (a) Geological map and (b) a column section of the Mersin ophiolite (Parlak et al., 1996). 
amphibolites in turn intruded by a thin diabase dyke (Fig. 16b). A small tectonic inclusion of coarse-grained amphibolite is exposed beneath the harzburgitic mantle tectonites on the road to Gözne-Arslanköy, as a third outcrop of the metamorphic sole (Fig. 15).

The Mersin ophiolite is well exposed in several NWSE-trending deep valleys dissecting Miocene carbonates on the southern flank of the Tauride Platform (Parlak, 1996). It has an $\sim 6-\mathrm{km}$-thick complete oceanic lithospheric section except for sheeted dykes (Fig. 15). From bottom to top, it is characterized by harzburgitic mantle tectonites, ultramafic to mafic cumulates and volcanics. The best exposures are observed along the Sorgun valley in the western part of the massif. Mantle tectonites rest tectonically on a mélange unit to the south of Sorgun Village along the Sorgun valley in the west (Fig. 15). Although the mantle tectonites are highly sheared and serpentinized along the contact, they exhibit good foliation patterns characterized by alternations of dunite, harzburgite and orthopyroxenite banding in several places. A number of isolated dykes intersect at different structural levels. A dunitic zone with bands and pods of chromitite within the Moho-transition zone is observed below the ultramafic cumulates about 1-km thick, that start with dunite and are followed upward by dunite and wehrlite alternations (Parlak et al., 1996), in turn covered by clinopyroxenites towards the south. A succeeding zone of alternating wehrlite and olivine gabbroic cumulates is seen before the mafic cumulates. The ultramafic cumulates exhibit adcumulate textures and display structures such as igneous lamination, size grading and rhytmic layering (Fig. 15). The mafic cumulates, $\sim 2 \mathrm{~km}$ thick, are dominated by olivine gabbro, leucogabbro, gabbro and anorthosite (Parlak et al., 1996).
The mafic cumulates show rhythmic to graded layering and are characterized by adcumulate, mesocumulate and orthocumulate textures. Two distinct series of volcanic rocks are present. The first outcrop of the volcanics is seen in the Sorgun valley where it is intercalated with radiolarites and pelagic limestones of Late Jurassic to Early Cretaceous Age. The second outcrop of the volcanic rocks is located in the Findıkpınarı region and is represented by pillow lavas and lava flows probably of Late Cretaceous Age. The pillows are approximately $50 \mathrm{~cm}$ in diameter and their vesicles are filled by pyrite, calcite and quartz (Parlak et al., 1997).

\subsubsection{Petrogenesis and geochronology of the Mersin ophiolite}

Major and trace element geochemistry of the ultramafic to mafic cumulates suggest that they formed within the Inner Tauride Ocean in a supra-subduction zone tectonic setting (Parlak et al., 1996). The crystallization order of the cumulates is: olivine \pm chromian spinel+ clinopyroxene+plagioclase and orthopyroxene. The presence of highly magnesian olivine $\left(\mathrm{Fo}_{91-80}\right)$ and clinopyroxene $\left(\mathrm{Mg} \#_{95-77}\right)$, as well as Ca-rich plagioclase $\left(\mathrm{An}_{95-91}\right)$ in the cumulate rocks suggests a subduction-related setting (Parlak et al., 1996). The geochemistry of the isolated diabase dykes cutting the mantle tectonites and the cumulates of the Mersin ophiolite, suggests their derivation from an island arc tholeiitic magma (Parlak et al., 1997; Parlak and Delaloye, 1996). Basaltic rocks associated with deep marine sediments show an alkaline affinity and are more akin to seamount-type alkaline basalt formed in a within plate setting, whereas the major and trace element chemistry of the second group of volcanic rocks suggests a subduction-related setting (Parlak
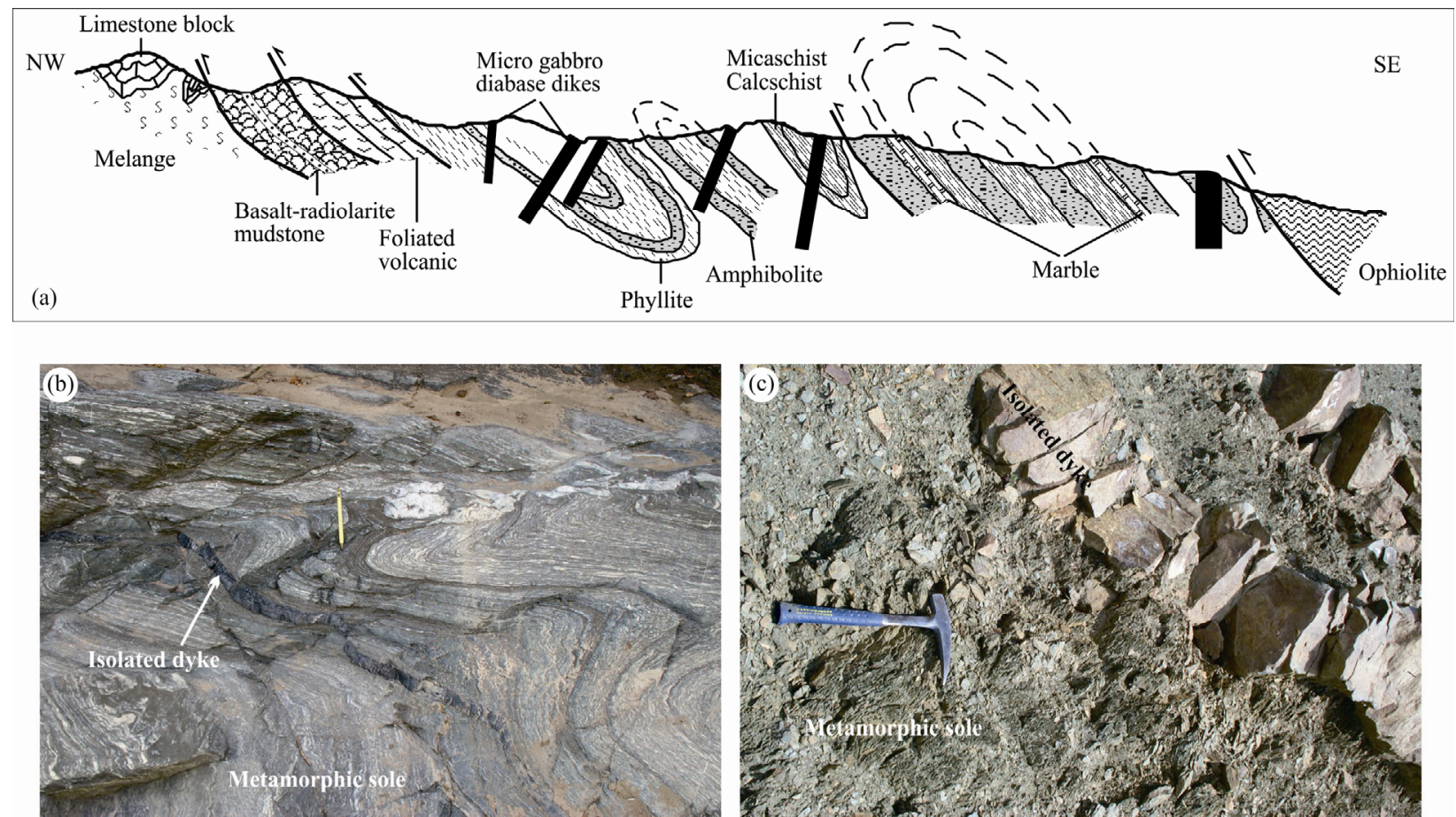

Figure 16. (a) Cross-section showing the structural relationships of subophiolitic metamorphic rocks of the Mersin ophiolite in the Findıkpınarı area. Field views of post-metamorphic dykes emplaced into ductily (b) and brittly (c) deformed metamorphic sole rocks. 
et al., 1997). Zircon separates from the cumulate gabbroic rocks, dated by LA-MC-ICP-MS, yielded a crystallization age of $82.8 \pm 4.0 \mathrm{Ma}$ (Parlak et al., 2013). Isolated dykes cutting the Mersin ophiolite were also dated by ${ }^{40} \mathrm{Ar} /{ }^{39} \mathrm{Ar}$ techniques (Dilek et al., 1999; Parlak and Delaloye, 1996). Diabase dykes cutting the metamorphic sole yielded wholerock ages of $89.8 \pm 0.3$ to $86.3 \pm 0.3 \mathrm{Ma}$ (Parlak and Delaloye, 1996), whereas the dykes in the mantle tectonites yielded a hornblende cooling age of 91.0 $\pm 0.8 \mathrm{Ma}$ (Dilek et al., 1999). Çelik (2008) reported whole-rock K-Ar cooling ages of $88.4 \pm 3$ to $88.8 \pm 2 \mathrm{Ma}$ for the dykes cutting the metamorphic sole.

The geochemistry of the amphibolites from the metamorphic sole suggests a derivation from alkali ocean island alkali basalts, mid-ocean ridge and island arc tholeiitic basalts (Çelik, 2008; Parlak et al., 1997). Thuizat et al. (1981) reported Late Cretaceous ( $94 \pm 4$ and $98 \pm 4 \mathrm{Ma})$ $\mathrm{K}-\mathrm{Ar}$ ages on hornblende separates. Parlak et al. (1995b) reported a 93.4 $\pm 2.2 \mathrm{Ma} \mathrm{K}-\mathrm{Ar}$ isochron age for hornblendes from the metamorphic sole and Çelik (2008) also reported a $93.8 \pm 3$ Ma cooling age for hornblende separates. Similar Late Cretaceous cooling ages (96 to $91 \mathrm{Ma}$ ) by the ${ }^{40} \mathrm{Ar} /{ }^{39} \mathrm{Ar}$ technique on hornblende separates have also been documented (Dilek et al., 1999; Parlak and Delaloye, 1999). Pressure-temperature conditions $(P / T)$ under which the metamorphic sole rocks formed were $522 \pm 15{ }^{\circ} \mathrm{C}$ and $\sim 5$ kbar (Çelik, 2008).

\subsection{Alihoca Ophiolite}

The northern margin of the Bolkardağ Platform is bounded by the east-west trending, deformed and dismembered Alihoca ophiolite (Fig. 14). The tectonic contact between the Bolkardağ Platform and the Alihoca ophiolite is marked by discontinuous exposures of blueschists (van der Kaaden, 1966; Blumenthal, 1955). Glaucophane-bearing HP rocks are present within the mafic volcanics of the Lower Triassic series of the Bolkar Platform (Pourteau et al., 2010) and within blocks of the ophiolitic mélange (van der Kaaden, 1966). Another locality of HP rocks is exposed beneath the K1z1ltepe ophiolite, a klippe above the Mesozoic carbonate platform of the Bolkardag Platform farther south relative to the Alihoca ophiolite (Fig. 14). A thin metamorphic sole beneath the Kiziltepe ophiolite was overprinted by blueschist-facies metamorphism during the Late Cretaceous (Dilek and Whitney, 1997).

The Alihoca ophiolite is represented by highly serpentinized peridotites, pyroxenite, ultramafic to mafic cumulates, isotropic gabbros and minor extrusive rocks. The mafic cumulates also include thin bands and lenses of wehrlite and pyroxenite (Dilek et al., 1999; Dilek and Whitney, 1997). Microgabbroic to diabasic dykes up to $2 \mathrm{~m}$ thick intrude all the units except volcanics. The Alihoca ophiolite and its related mélange unit are overlain by the Çiftehan Formation (Demirtaşlı et al., 1984) that has a basal conglomerate at the bottom gradually passing upwards into cherty limestone and red pelagic limestone of CampanianMaastrichtian age.

\subsubsection{Petrogenesis and geochronology of the Alihoca ophiolite}

Pyroxenes within ultramafic cumulates (clinopyroxenite and websterites) of the Alihoca ophiolite have restricted chemical compositions (e.g., diopside $\mathrm{En}_{48} \mathrm{Fs}_{6} \mathrm{Wo}_{46}-\mathrm{En}_{44} \mathrm{Fs}_{10} \mathrm{Wo}_{46} ;$ orthopyroxene $\mathrm{En}_{84} \mathrm{Fs}_{14} \mathrm{Wo}_{2}-$ $\mathrm{En}_{75} \mathrm{Fs}_{23} \mathrm{Wo}_{2}$ ). These rocks have relatively high $\mathrm{Mg}$ olivine $\left(\mathrm{Fo}_{85}\right)$ and highly calcic plagioclase $\left(\mathrm{An}_{98-96}\right)$ (Dilek et al., 1999). This feature points to a highly refractory parental magma composition and possibly hydrous crystallization conditions (Dilek et al., 1999). The geochemistry of the isolated diabase dykes cutting the serpentinized mantle tectonites as well as the crustal rocks of the Alihoca ophiolite, suggests that they represent magma compositions typical of evolved island arc tholeiites from a depleted mantle source that underwent metasomatism introducing large-ion-lithophile (LIL) element and light rare earth element (LREE) enriched fluids (Dilek et al., 1999). Dilek and Whitney (1997) suggested the following history for the formation of the metamorphic sole and its blueschist overprint: (1) metamorphism of basaltic protoliths in the amphibolite facies during inception of an intra-oceanic subduction zone, (2) infiltration of amphibolite by fluid along fractures and grain boundaries at high $P / T$ in this subduction zone, (3) cessation of pervasive deformation and continued, post-kinematic growth of high $P / T$ minerals and (4) exhumation and greenschist-facies retrogressive metamorphism.

${ }^{40} \mathrm{Ar} /{ }^{39} \mathrm{Ar}$ hornblende dating of amphibolite from the metamorphic sole of the Kiziltepe ophiolite yielded a cooling age of $90.6 \pm 0.9 \mathrm{Ma}$ and hornblendes separated from an isolated dyke cutting the layered gabbro-pyroxenite of the Alihoca ophiolite yielded a cooling age of $90.8 \pm 0.8$ Ma (Dilek et al., 1999).

\subsection{Pozantı-Karsantı Ophiolite}

The Pozanti-Karsanti ophiolite is exposed in the eastern Aladag region of the Tauride belt and covers an area of approximately $1300 \mathrm{~km}^{2}$ to the east of the Ecemiş strike-slip fault of southern Turkey (Parlak et al., 2002, 2000; Parlak, 2000; Polat et al., 1996; Lytwyn and Casey, 1995; Çatakl1, 1983; Tekeli et al., 1983; Juteau, 1980; Bingöl, 1978; Çakır, 1978) (Fig. 14). An imbricated stack of thrust sheets resting upon the eastern Taurus autochthon is exposed in the Aladag region (Polat et al., 1996; Blumenthal, 1947). The upper thrust sheets are characterized by ophiolite-related rock assemblages, namely ophiolitic mélange, a dynamothermal metamorphic sole and oceanic lithospheric sections, whereas the lower thrust sheets consist of platform-type carbonates, ranging in age from Late Devonian to Early Cretaceous (Tekeli et al., 1983). We describe the rock units from the upper thrust sheets below.

A Campanian to Maastrichtian unmetamorphosed ophiolitic mélange is composed of a variety of igneous, metamorphic and sedimentary blocks structurally dispersed in a serpentinitic to pelitic matrix (Polat and Casey, 1995; Tekeli et al., 1983). The ophiolitic mélange was subdivided into three tectonic slices based on the origin of the blocks 
and the surrounding matrix, field relationships and deformation style (Polat et al., 1996). These are: (1) an upper tectonic slice characterized by a serpentinitic matrix with ophiolitic and metamorphic blocks, (2) a middle tectonic slice composed of a pelitic matrix with ophiolite blocks at the top and limestone blocks at the bottom, and (3) a lower tectonic slice consisting of brittlely-deformed pelitic matrix at the top and tectonic breccia at the bottom. The mélange unit formed as a result of subduction-accretion processes and became attached to the base of the Pozant1Karsant1 ophiolite during final emplacement onto the Tauride Platform (Polat et al., 1996; Tekeli et al. 1983).

The metamorphic sole rocks of the Pozant1-Karsant1 ophiolite crop out at different locations in a constant structural position between the harzburgitic mantle tectonites and the ophiolitic mélange (Fig. 17). The dynamothermal metamorphic sole displays a typical inverted metamorphic sequence grading from amphibolite facies directly beneath the highly sheared harzburgitic tectonite to greenschist facies close to the mélange contact (Çelik, 2007; Polat et al., 1996; Lytwyn and Casey, 1995; Thuizat et al., 1978). The metamorphic sole rocks are wellexposed in the northern part of the Pozant1-Karsant1 ophiolite in Aladag region (Fig. 17). The first outcrop is located approximately $8 \mathrm{~km}$ to the NNE of Ulupinar Village along the Zorkunlu valley (Fig. 17) where it has a structural thickness of around $450 \mathrm{~m}$ (Polat et al., 1996). The contact between the metamorphic sole and the ophiolite is defined by a $1.5-2 \mathrm{~m}$ thick zone of strongly-sheared tectonically intercalated serpentinized harzburgitic mantle tectonites and amphibolites (Figs. 18a, 18e). In this zone, the thicknesses of bands in the amphibolites and highly-sheared hazburgitic tectonites range from 4 to $15 \mathrm{~cm}$. Foliation surfaces both in the amphibolites and the mantle tectonites are concordant (N-S/70-80E) (Fig. 18b). This contact is interpreted as indicating an intra-oceanic decoupling surface along which the volcanics on the top of the down-going slab were metamorphosed up to upper amphibolite facies and attached to the base of the hanging wall plate (Spray, 1984). The contact between the metamorphic sole and the serpentinized harzburgite is crosscut by a 7-8-m-thick mafic dyke which postdates intraoceanic metamorphism and high-temperature ductile deformation (Figs. 18a, 18d). Individual dykes are also observed to cut the metamorphic sole and the mantle tectonites at different structural levels. The metamorphic sole displaying granoblastic to nematoblastic textures, is represented by garnet amphibolite at the contact beneath the mantle tectonites and amphibolite to plagioclase-epidoteamphibole schist at a lower structural level. Metavolcanic, metachert, metapelite and quartzite rock associations are observed toward the contact with the ophiolitic mélange (Çelik, 2007; Polat et al., 1996). Mesostructures within the metamorphic sole suggest southward emplacement of the ophiolite (Figs. 18f, 18g). The second outcrop is located a few hundred meters to the north of Kapuzbaş1 Village in the Aladağ region where alternations of amphibolite, quartzplagioclase amphibolite, calcschist, micaschist and micaamphibole schist are observed (Fig. 17). The metamorphic sole rocks display granoblastic, nematoblastic and lepidoblastic textures, are gently folded and contain marble lenses. The third outcrop is located $1 \mathrm{~km}$ to the south of Delialiuşağı Village (Fig. 17) where the metamorphic sole rocks are tectonically sandwiched between serpentinized mantle tectonites and ophiolitic mélange. The structural thickness of the metamorphic sole is approximately $120 \mathrm{~m}$ (Figs. 19a, 19d). These rocks are gently folded and contain a layer of highly deformed calcschist (Fig. 19c). The metamorphic sole rocks are represented by plagioclasemica-amphibole schist, display nematoblastic to lepidoblastic textures and are intruded by isolated dykes (Fig. 19b). Apatite, rutile, sphene and zircon are common accessory minerals in the metamorphic sole rocks.
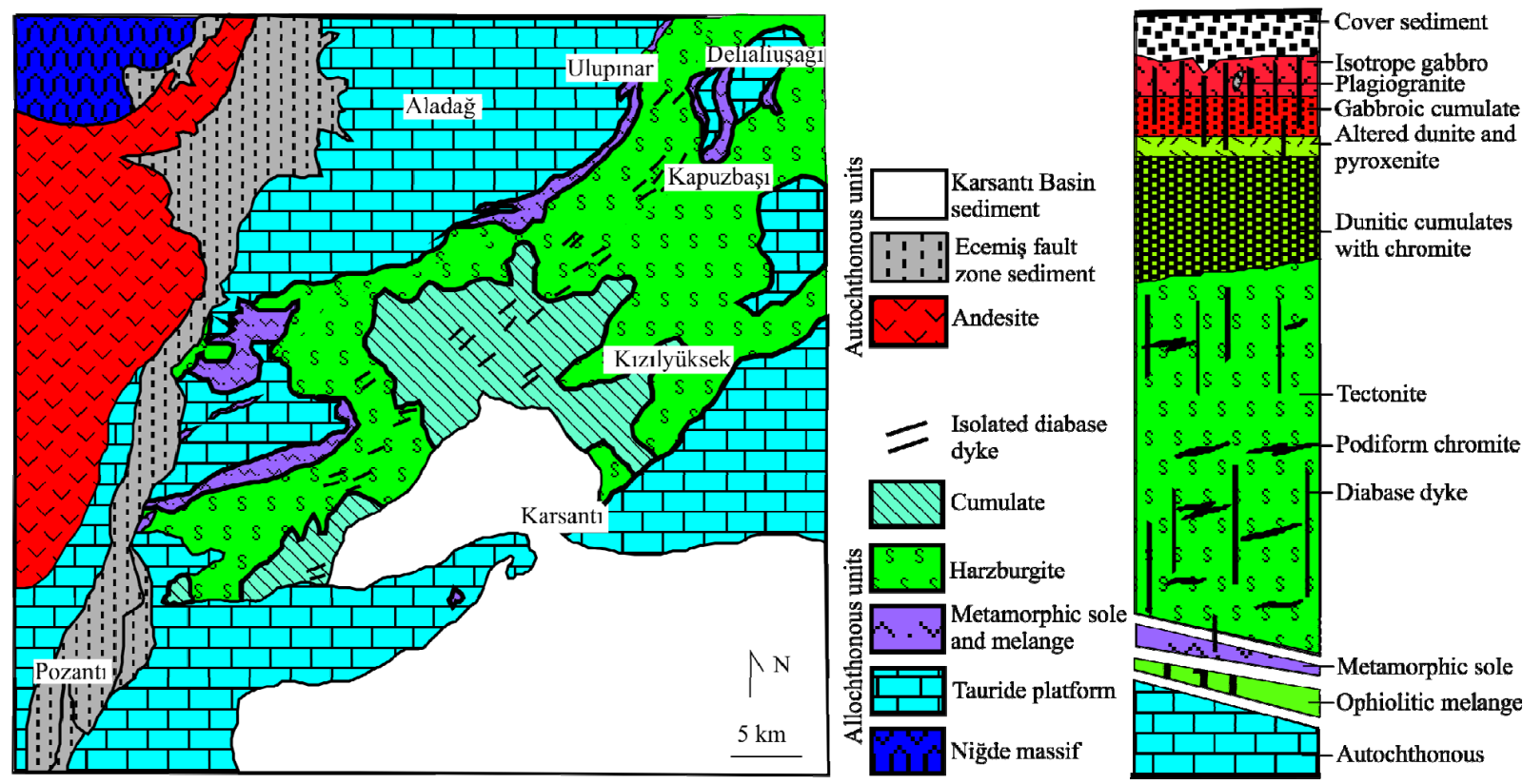

Figure 17. (a) Geological map and (b) column section of the Pozant1-Karsantı ophiolite (Bingöl, 1978). 

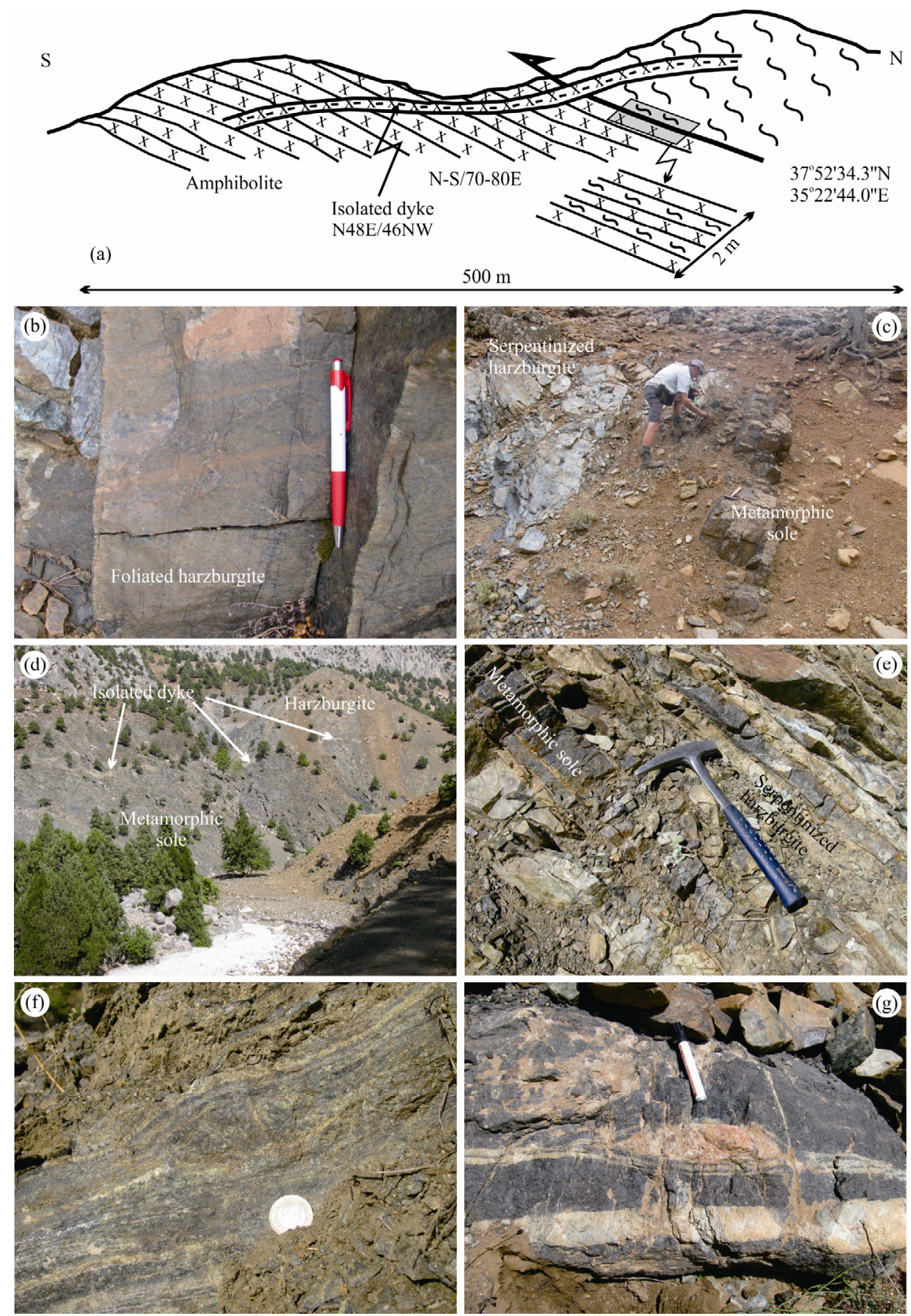

Figure 18. (a) Cross section showing the field relations of mantle tectonite, metamorphic sole and a cross-cutting dyke in the Pozant1-Karsantı ophiolites at Ulupınar Village, field views of (b) foliated peridotite, (c) tectonic contact between mantle peridotite and the metamorphic sole, (d) dyke emplacement through the oceanic decoupling surface between the mantle peridotite and the metamorphic sole, (e) close up view of the tectonic intercalation of serpentinite and amphibolite along the oceanic decoupling surface, (f) and (g) mesostructures within the metamorphic sole showing top-to-south shearing.

The Pozant1-Karsantı ophiolite is characterized by from bottom to top, mantle tectonites, ultramafic to mafic cumulates, and isotropic gabbro with plagiogranite intrusions (Bingöl, 1978). Mantle tectonites constitute approximately $60 \%$ of the whole ophiolite, are exclusively represented by harzburgite and display plastic deformation indicated by alternating bans of orthopyroxenite and dunite (Fig. 18b). The harzburgitic tectonites generally exhibit porphyroclastic textures and are variably serpentinized toward the top. The mantle tectonites are very fresh close to the contact with the metamorphic sole, include chromitite pods surrounded by dunitic envelopes at different structural levels and are intruded by gabbro and diabase dykes. The ultramafic cumulates generally rest on the mantle tectonites with a tectonic contact. A discordant contact relationship was also reported by Bingöl and Juteau (1977) in the Kizılyüksek region (Fig. 17). The ultramafic cumulates start with a $\sim 2-\mathrm{km}$-thick dunite layer at the bottom in which there are well-known stratiform chromite deposits (Bingöl, 1978). Above this, a transition zone is characterized by 

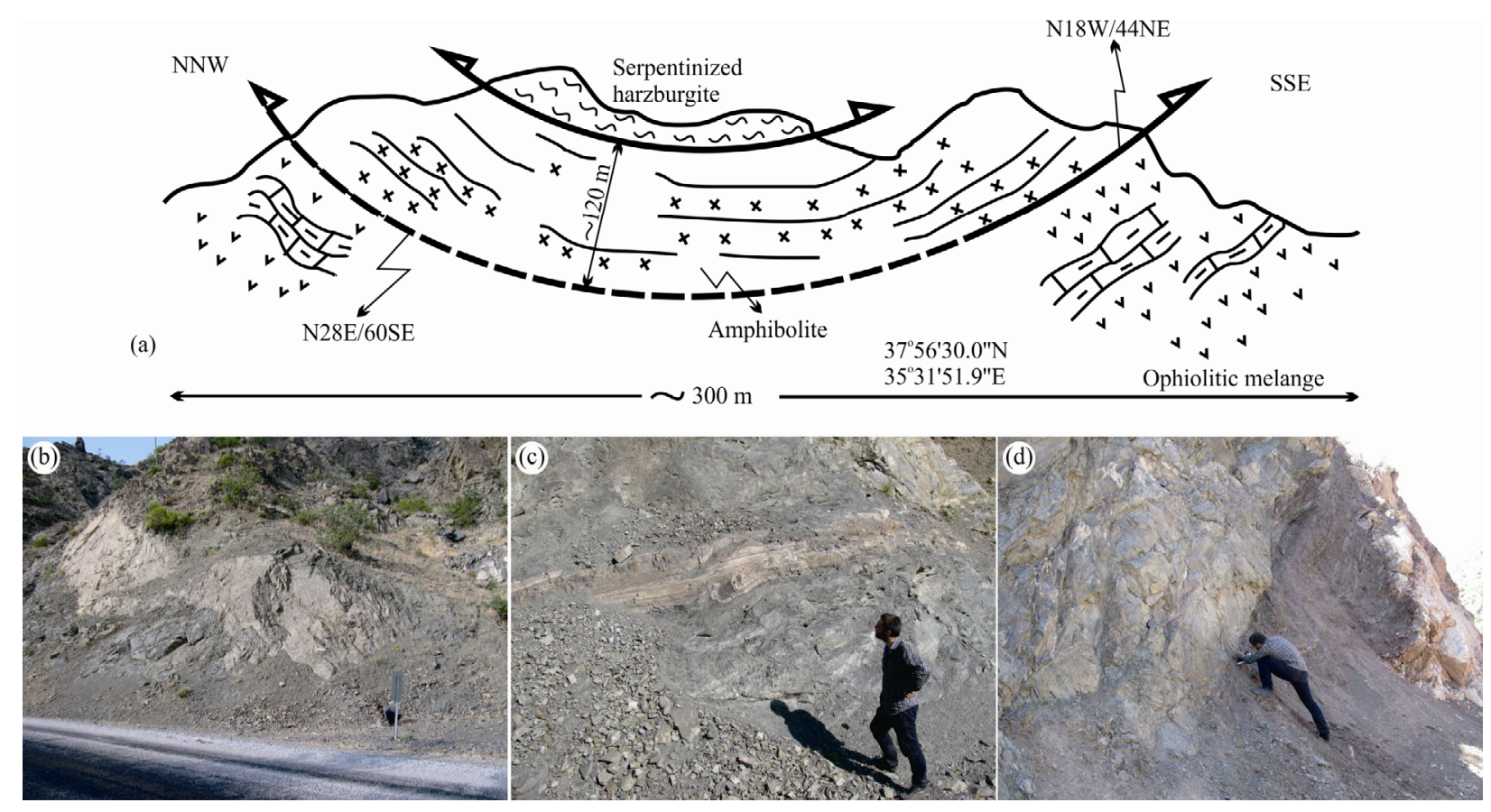

Figure 19. (a) Cross section showing the field relations of mantle tectonites, metamorphic sole and ophiolitic mélange in the Pozant1-Karsant1 ophiolite at Delialiuşağı Village, field views of (b) dyke emplacement in the metamorphic sole, (c) a deformed calcschist-marble layer within the metamorphic sole, and (d) the tectonic contact between the metamorphic sole and the ophiolitic mélange.

alternating olivine- and pyroxene-rich rocks, namely dunite, wehrlite, olivine clinopyroxenite, clinopyroxenite and olivine websterite (Parlak et al., 2002). Gabbroic cumulates composed almost exclusively of gabbronorites constitute $40 \%$ of the whole cumulate section and are around $1300 \mathrm{~m}$ thick (Bingöl, 1978). They exhibit accumulatemesocumulate textures and show magmatic accumulation features such as igneous lamination, crystal size grading and rhythmic layering. Olivine-rich gabbroic cumulates are also documented in the western part of the Pozant1-Karsant1 ophiolite (Çatakl1, 1983). Some parts of the gabbros are isotropic in character and exhibit doleritic to subophitic texture (Parlak et al., 2000). A number of isolated microgabbro and diabase dykes cut the mantle tectonites and metamorphic sole at different structural levels ans also the contact between the metamorphic sole and the harzburgitic mantle tectonites (Figs. 17, 18, 19). They do not cut the underlying mélange and Tauride Platform rocks, indicating that some dyke emplacement postdated the formation of the ophiolite and the metamorphic sole but pre-dated its final obduction onto the Tauride Platform (Çelik, 2007; Parlak, 2000; Lytwyn and Casey, 1995; Thuizat et al., 1981; Çakır et al., 1978).

\subsubsection{Petrogenesis and geochronology of the Pozantı- Karsantı ophiolite}

Geochemical studies on the mantle section of the Pozant1-Karsant1 ophiolite suggest the existence of both weakly depleted mantle peridotites produced by low degrees of partial melting in a mid-ocean ridge environment and re-melted and highly-depleted mantle peridotites formed in a supra-subduction zone setting (Saka et al., 2014). The whole rock and mineral chemistry of the cumulate rocks suggests that the primary magma generating the Pozanti-Karsanti ophiolite was compositionally similar to those observed in modern island arc tholeiitic sequences (Parlak et al., 2000). The mineral chemistry of the basal ultramafic cumulates (dunite, wehrlite, websterite) shows evidence of high-pressure crystallization, typical for the base of an island arc system whereas the mineral chemistry of the cumulate gabbronorites indicates lower-pressure crystallization by the presence of amphibole (Parlak et al., 2002). Isolated post-metamorphic diabase dykes which intrude the metamorphic sole, the mantle tectonites and the crustal sequence, are subalkaline in character and compositionally similar to island arc tholeiitic basalts and basaltic andesites. They display large-ion-lithophile (LIL) element enrichment and are depleted in high-field-strength (HFS) elements $(\mathrm{Nb}, \mathrm{Ti}, \mathrm{Y})$ relative to N-MORB. The presence of positive Th and LIL anomalies and a negative $\mathrm{Nb}$ anomaly relative to the other incompatible elements, are thought to indicate a subduction-related setting during their emplacement (Parlak, 2000). Çelik (2007) documented latestage pyroxenite dykes intruding the metamorphic sole beneath the Pozant1-Karsant1 ophiolite that were interpreted to be a result of offaxis magmatism fed by melts that originated within an asthenospheric window caused by slab break-off. Lytwyn and Casey (1995) postulated that the post-metamorphic dykes in the ophiolite as well as the metamorphic sole were emplaced due to a ridge subduction event during intraoceanic transport of the Pozant1-Karsant1 ophiolite. Thuizat et al. (1978) reported a K-Ar age of $71 \pm 3$ $\mathrm{Ma}$ on a plagioclase separate from the post-metamorphic dykes. A similar young LA-MC-ICP-MS U-Pb zircon age of $69.1 \pm 2.1 \mathrm{Ma}$ has recently been obtained from crustal rocks (gabbro cumulate) of the Pozant1-Karsant1 ophiolite 

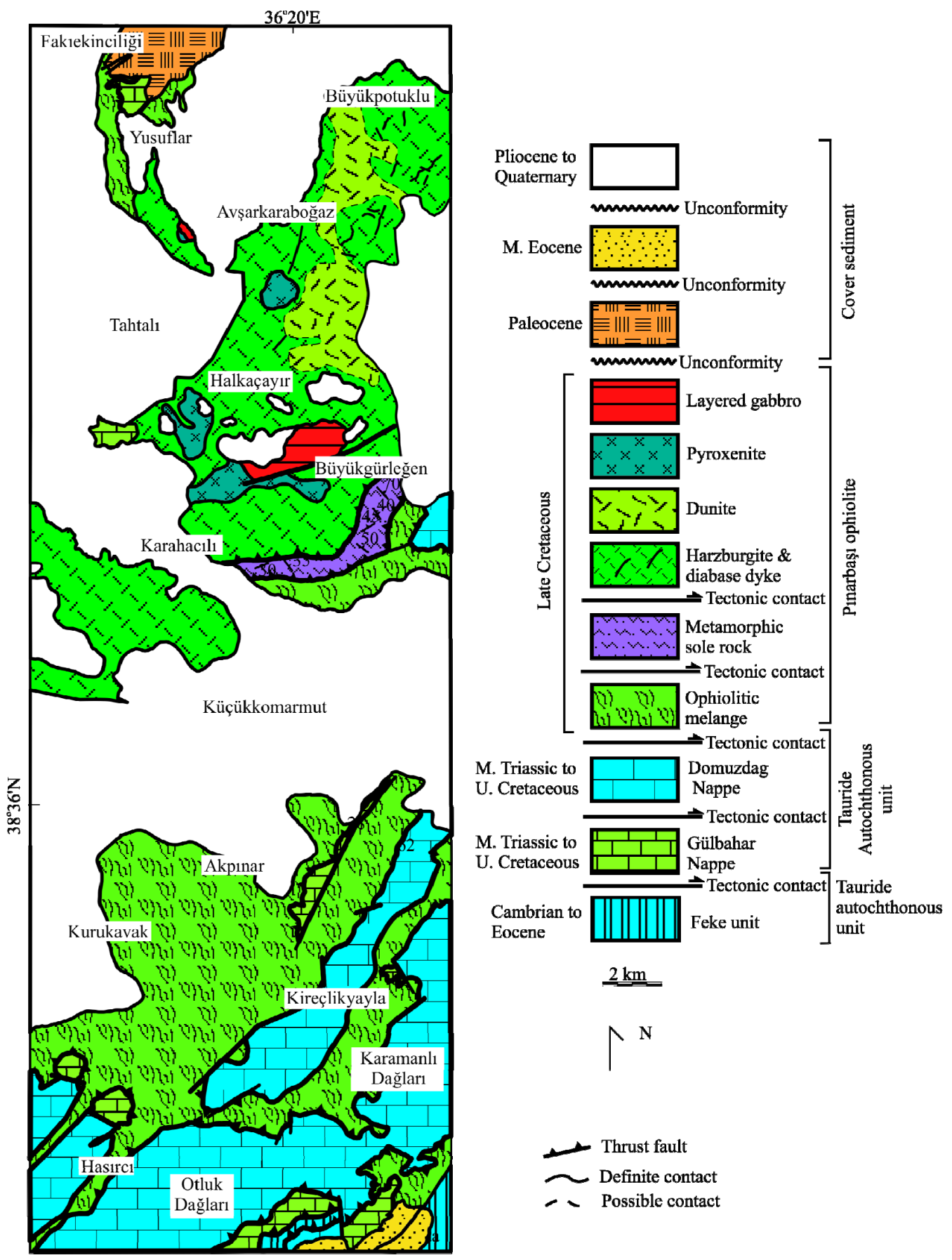

Figure 20. Geological map of the Pınarbaşı ophiolite (Vergili and Parlak, 2005).

(Parlak et al., 2013) and is interpreted as reflecting island arc tholeiitic (IAT) melt generation in an SSZ setting along the Inner Tauride Ocean prior to emplacement of the ophiolites onto the Tauride-Anatolide Platform (Parlak et al., 2013).

The whole-rock and mineral chemistry of amphibolites from the metamorphic sole rocks suggest their derivation from different precursors, namely alkaline basalt and NMORB basalt (Lytwyn and Casey, 1995), ocean island basalt (OIB), mid-ocean ridge basalt (MORB) and island arc basalt (IAT) (Çelik, 2007) or OIB-like alkali basalt to $\mathrm{N}$ - to E-MORB (Polat et al., 1996). The alkaline, OIB-like basalts were mainly metamorphosed in the amphibolite facies and the $\mathrm{N}$ - to E-MORB lavas and their pelagic intercalations were metamorphosed under greenschist facies conditions (Polat et al., 1996; Lytwyn and Casey, 1995). Polat et al. (1996) suggested on the basis of geochemical work that intra-oceanic subduction may have taken place in the vicinity of an off-axis plume or a plume-centered spreading ridge within the Inner Tauride Ocean where the lithosphere would have been young and hot, providing the thermal source for metamorphism. Pressure-temperature conditions $(P / T)$ under which the metamorphic sole rocks formed were $570-580{ }^{\circ} \mathrm{C}$ and 5-6 kbar (Çelik, 2007). ${ }^{40} \mathrm{Ar} /{ }^{39} \mathrm{Ar}$ age dating on separates of hornblende $(90.4 \pm 0.9$ to $91.7 \pm 0.6 \mathrm{Ma})$ and muscovite $(92.4 \pm 1.3 \mathrm{Ma})$ from the 
metamorphic sole rocks of the Pozant1-Karsant1 ophiolite yielded Late Cretaceous ages (Çelik et al., 2006; Dilek et al., 1999). Earlier, Thuizat et al. (1981) had also reported similar Late Cretaceous (Cenomanian-Turonian) K-Ar ages on hornblende ( $95 \pm 4 \mathrm{Ma})$ and biotite $(92 \pm 3 \mathrm{Ma})$ separates.

\subsection{Pınarbaşı (Kayseri) Ophiolite}

The Pınarbaşı (Kayseri) ophiolite, emplaced onto the Tauride Platform in the Late Cretaceous, covers an area of approximately $500 \mathrm{~km}^{2}$ in the southeastern part of the central Anatolian crystalline complex (CACC) (Göncüoğlu et al., 1996-1997). The eastern Tauride autochthon (Geyikdağ unit of Özgül, 1976), ranging in age from Cambrian to Eocene, is tectonically overlain by allochthonous thrust sheets that are represented by a platform-type carbonate-dominated lower thrust sheet and an ophiolite-related upper thrust sheet (Tekeli et al., 1983; Blumenthal, 1947). The allochthonous lower thrust sheet in

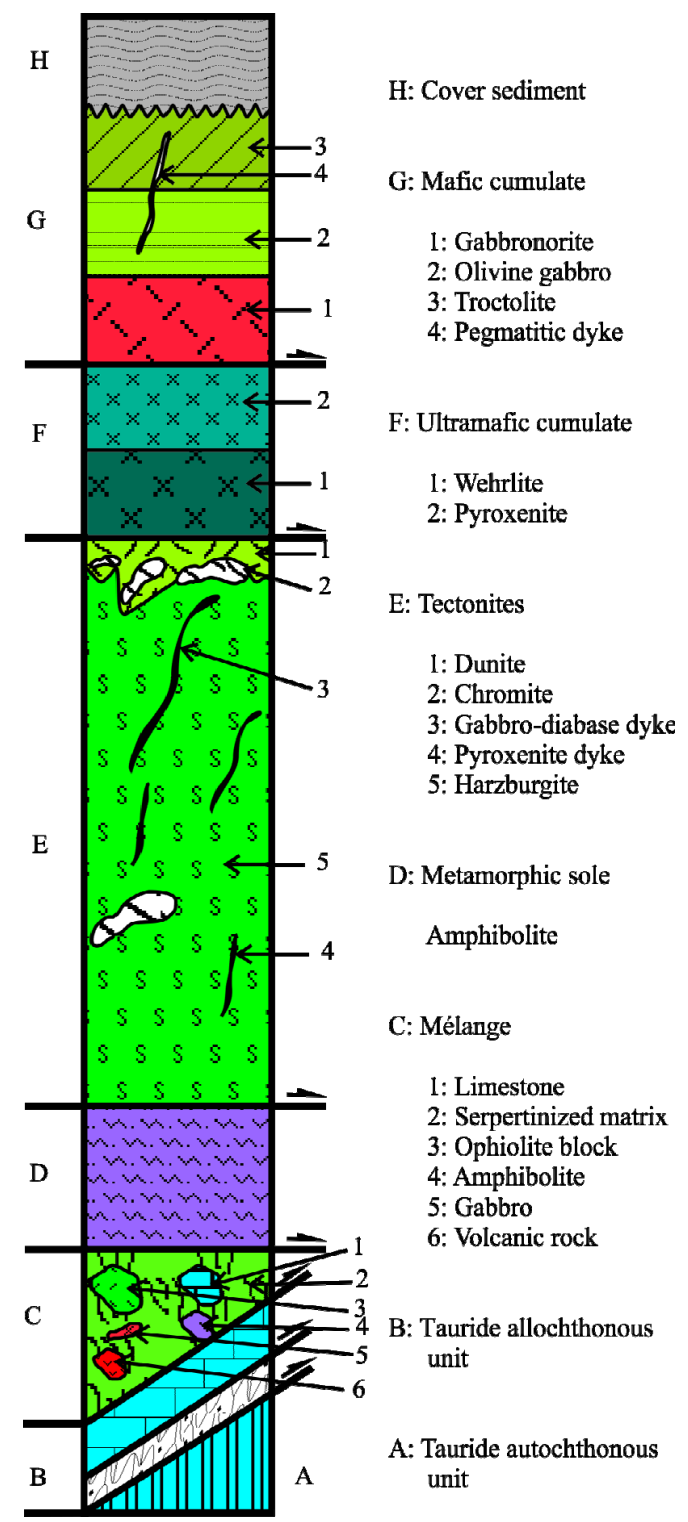

Figure 21. Column section of the Pınarbaş1 ophiolite and tectonostratigraphic units in the eastern Tauride belt (Vergili and Parlak, 2005). the region is composed of, in ascending order, the Gülbahar and Domuzdağ nappes (Figs. 20, 21). The Gülbahar nappe, ranging in age from Middle Triassic to Late Cretaceous, consists mainly of mafic volcanics, calciturbidites, radiolarite and chert-bearing micritic limestone and cherty limestone (Şenel, 1997a, b). The Domuzdağ nappe (Poisson, 1977), consisting of Mesozoic platform type carbonates, rests tectonically on the Gülbahar nappe (Figs. 20, 21). The overlying allochthonous upper thrust sheet is represented, from bottom to top, by an ophiolitic mélange, a metamorphic sole and an ophiolite sequence (Figs. 20, 21). The Upper Campanian-Maastrichtian, unmetamorphosed ophiolitic mélange comprises blocks of ophiolite-derived, igneous (serpentinized harzburgitic to dunites, gabbro, diabase and volcanics), metamorphic (amphibolite) and sedimentary rocks (volcanogenic sandstone, radiolarite and shale) enclosed in a serpentinitic to pelitic matrix (Erkan et al., 1978). The ophiolitic mélange crops out in the southern part of the Pınarbaşı (Kayseri) ophiolite. The metamorphic sole is tectonically sandwiched between the overlying harzburgitic tectonites and underlying ophiolitic mélange between Büyükgürleğen and Karahacılı (Fig. 20). It exhibits well-developed foliation patterns and has a thickness of around $250 \mathrm{~m}$. The metamorphic sole displays inverted metamorphic zonation, grading from amphibolite facies directly beneath the highly sheared harzburgitic tectonite to greenschist facies near the mélange contact. The metamorphic sole rocks display granoblastic to nematoblastic textures and are represented by amphibolite, plagioclase amphibolite, plagioclase-amphibole schist, epidoteplagioclase-amphibole schist and calcschist (Vergili and Parlak, 2005). The Pınarbaş1 ophiolite is exposed in the northern part of the study area (Fig. 20) and comprises the lower parts of an oceanic lithosphere system such as mantle tectonites and ultramafic and mafic cumulates (Vergili and Parlak, 2005). Contacts between units are tectonic. The mantle tectonites are represented by harzburgites and dunites with chromitite pods. The cumulate rocks consist of wehrlite, clinopyroxenite, troctolite, olivine gabbro and gabbro. Numerous isolated dykes of microgabbro, diabase and pyroxenite cut the mantle tectonites at all structural levels (Figs. 20, 21) but dyke emplacement is not observedin the metamorphic sole of the Pınarbaşı ophiolite. The Pınarbaşı ophiolite is covered by Paleocene conglomerate, pebbly sandstone, sandstone and limestone, deposited in an environment transitional between alluvial fan and lagoon (Erkan et al., 1978).

\subsubsection{Petrogenesis and geochronology of the Pınarbaşı ophiolite}

Vergili and Parlak (2005) found that isolated microgabbro-diabase dykes cutting the mantle tectonites are tholeiitic in character and their trace element contents suggest that they formed in a subduction-related environment. The amphibolites from the metamorphic sole beneath the Pınarbaş1 ophiolite exhibit two distinct geochemical features. The first group is alkaline and more akin to within-plate alkali basalts, whereas the second 
group is tholeiitic in nature and displays geochemical characteristics of island arc tholeiitic basalts (Vergili and Parlak, 2005).

The only available geochronological age determination for the Pınarbaşı ophiolite was zircon U-Pb dating of an isolated diabase dyke cutting the harzburgitic mantle tectonites. Zircon separates from that dyke yielded a very young crystallization age of $65.4 \pm 3.2 \mathrm{Ma}$ (Parlak et al., 2013).

\subsection{Divriği (Sivas) Ophiolite}

The Divriği ophiolite is located at the eastern end of the Tauride belt between Divriği and Çetinkaya (Sivas) in east-central Anatolia (Fig. 22). The area is characterized by, from bottom to top, autochthonous Tauride Platform carbonates, ophiolitic mélange, metamorphic sole, ophiolitic rocks, volcanic-sedimentary unit, granitoid rocks and cover sediments (Y1lmaz and Y1lmaz, 2004; Y1lmaz et al., 2001) (Fig. 23).

The Tauride Platform in the area consists of the Munzur limestone that exhibits continuous carbonate deposition from the Upper Triassic to the Upper Cretaceous. This unit comprises neritic limestones representing shallow to stable shelf conditions at the bottom and pelagic limestones at the top (Özgül and Turşucu, 1984). The Tauride Platform is tectonically overlain by the Yeşilyayla ophiolitic mélange (Fig. 22) that contains limestone blocks and metamorphic rock fragments set in a serpentinized matrix. The limestone blocks typically range from tens of meters to several hundred meters in size. The metamorphic rock fragments are represented by gneiss, amphibolite, metavolcanics, metaquartzite, calcschist and micaschist. The metamorphic sole has a constistant structural position between the mantle tectonites and the Yeşiltaşyayla mélange to the west of Ekinbaşı (Fig. 22). A pronounced regional foliation, mineral lineations and intrafolial folds were produced during intraoceanic deformation. The rocks exhibit granoblastic to nematoblastic textures and are represented by amphibolite, plagioclase amphibolite, plagioclase-amphibole schist, plagioclase-epidote-amphibole schist and marble (Fig. 24c) (Parlak et al., 2006). The metamorphic sole is cut by isolated unmetamorphosed diabase dykes (Fig. 24a). The Divriği ophiolite tectonically overlies the metamorphic sole and it displays a complete oceanic lithospheric section except for volcanics, namely serpentinized mantle tectonites, cumulates, isotropic gabbros and sheeted dykes (Fig. 23). Contacts from the cumulate to the isotropic gabbros and from the isotropic gabbros to the sheeted dykes are transitional. On the other hand, contacts between the other units are tectonic (Figs. 22, 23 ). The mantle tectonite is dominated by serpentinized harburgite containing dunitic lenses with chromite pods and subordinate lherzolite. The harzburgites are intruded by pyroxenite and gabbroic to diabasic dykes at different structural levels (Fig. 24b). The ultramafic to mafic cumulate rocks comprise dunite, wehrlite, olivine websterite, olivine gabbro and gabbro. The isotropic gabbros are represented by gabbro and diorite. The sheeted dykes are representeed by isolated dykes in the upper part of the isotropic gabbros and become dominant in the lower part of the sheeted complex. They range from 20 to $50 \mathrm{~cm}$

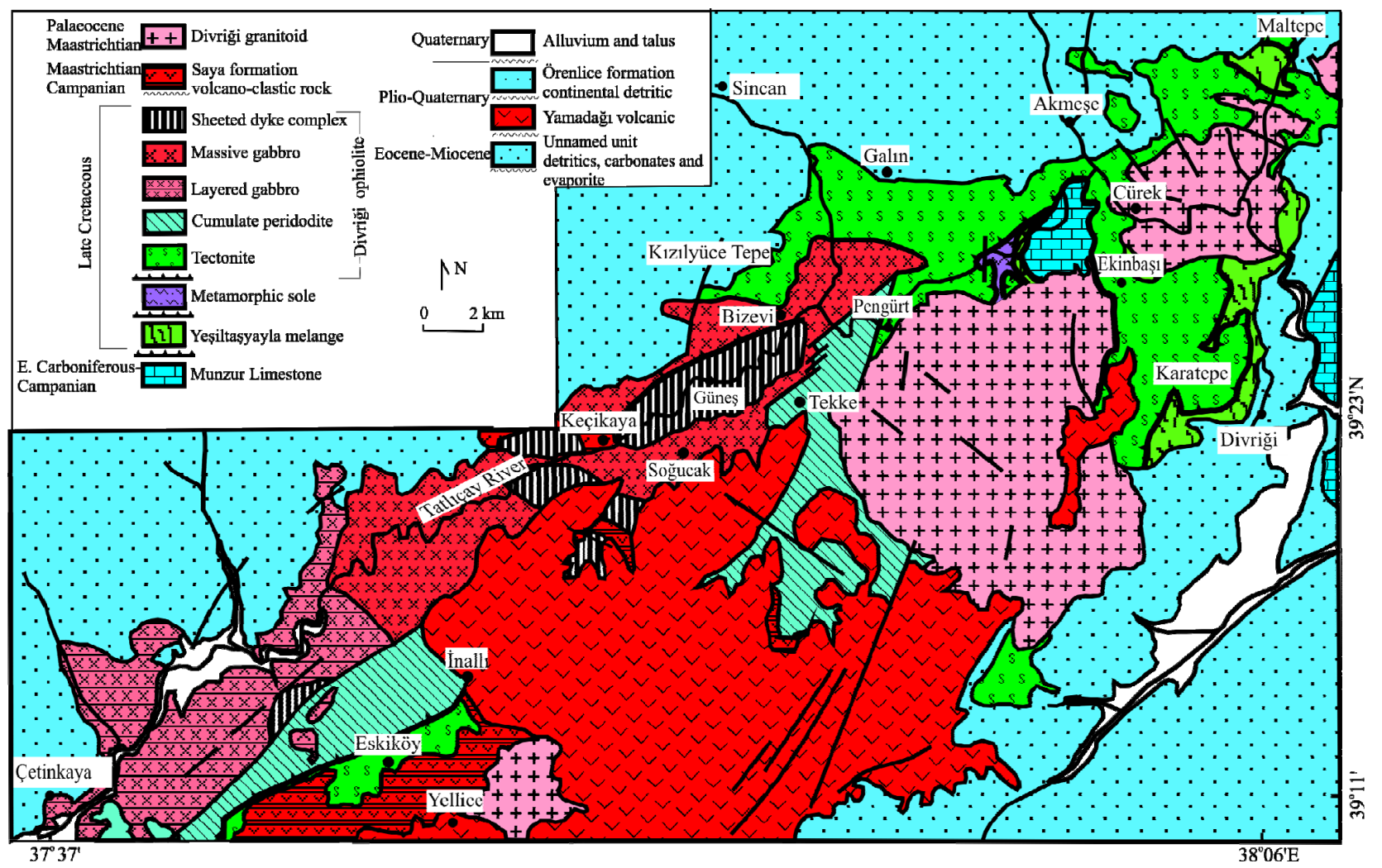

Figure 22. Geological map of the Divriği (Sivas) ophiolite (Yılmaz and Yılmaz, 2004; Yılmaz et al., 2001). 


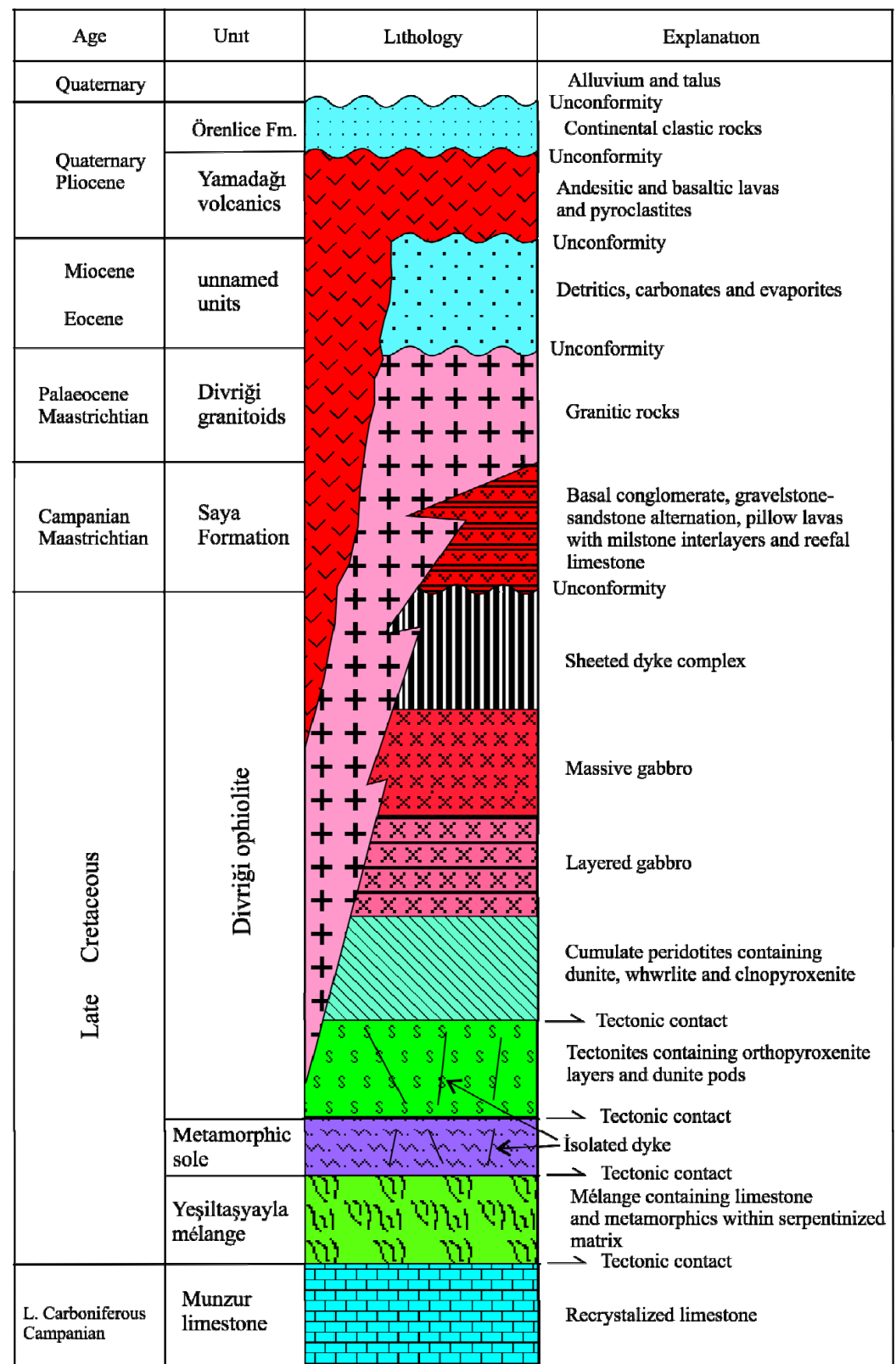

Figure 23. Column section of the Divriği (Sivas) ophiolite and tectonostratigraphic units in the eastern Tauride belt (Y1lmaz and Y1lmaz, 2004; Y1lmaz et al., 2001).

in width, and consist of diabase and microdiorite (Parlak et al., 2006). The ophiolitic rocks are unconformably overlain by a Campanian-Maastrichtian volcanic-sedimentary assemblage that in turn was intruded by basic dykes (Y1lmaz et al., 2001). Granitoid rocks in the Divriği region cut all the former units and have calcalkaline to alkaline compositions (Boztuğ et al., 2007; Kuşçu et al., 2010). They yielded zircon $\mathrm{U}-\mathrm{Pb}$ crystallization ages of $70.4 \pm 1.5$ to $67.7 \pm 1.4 \mathrm{Ma}$ (Campanian-Maastrichtian) (Parlak et al., 2013).

\subsubsection{Petrogenesis and geochronology of the Divriği ophiolite}

The gabbroic cumulate rocks of the Divriği ophiolite are characterized by high Ca-plagioclase $\left(\mathrm{An}_{97-83}\right)$, magnesian olivine $\left(\mathrm{Fo}_{87-76}\right)$ and clinopyroxene $\left(\mathrm{Mg} \#_{82-78}\right)$, suggesting that they formed in an arc setting (Parlak et al., 2005). Trace element contents of the sheeted dykes and the isotropic gabbros also exhibit subduction-related compositions (Parlak et al., 2005). The isolated dykes cutting the metamorphic sole and the mantle tectonites exhibit are alkaline in character and are geochemically similar to within-plate alkaline basalts (Parlak et al., 2006). The alkaline dykes are attributed to late-stage magmatism fed by melts that originated within an asthenospheric window caused by slab break-off, shortly before the emplacement of the Divriği ophiolite onto the Tauride Platform (Parlak et al., 2006). The metamorphic-sole rocks beneath the Divriği ophiolite can be divided into two groups with distinct geochemical features as tholeiitic and alkaline. The protolith of the tholeiitic amphibolites was derived from island-arc tholeiitic basalts, whereas the 
protolith of the second group was more akin to within-plate alkali basalts.

Zircon separates from a cumulate gabbro of the Divriği ophiolite were dated by U-Pb LA-MC-ICP-MS technique and yielded an $88.8 \pm 2.5$ Ma crystallization age (Parlak et al., 2013). Hornblende separates from the metamorphic sole rocks beneath the Divriği ophiolite were analysed by ${ }^{40} \mathrm{Ar} /{ }^{39} \mathrm{Ar}$ and they yielded robust plateau ages, ranging from $89.65 \pm 0.97$ to $87.49 \pm 0.48 \mathrm{Ma}$ (Parlak et al., 2013). An isolated post-metamorphic dyke cutting the metamorphic sole yielded an ${ }^{40} \mathrm{Ar} /{ }^{39} \mathrm{Ar}$ cooling age of $75.94 \pm 0.30 \mathrm{Ma}$ (Parlak et al., 2013).

\section{DISCUSSION}

The evolution of the easternmost Mediterranean region and Turkey can be explained by the opening and closure of several oceanic basins adjacent to Gondwana and Laurasia
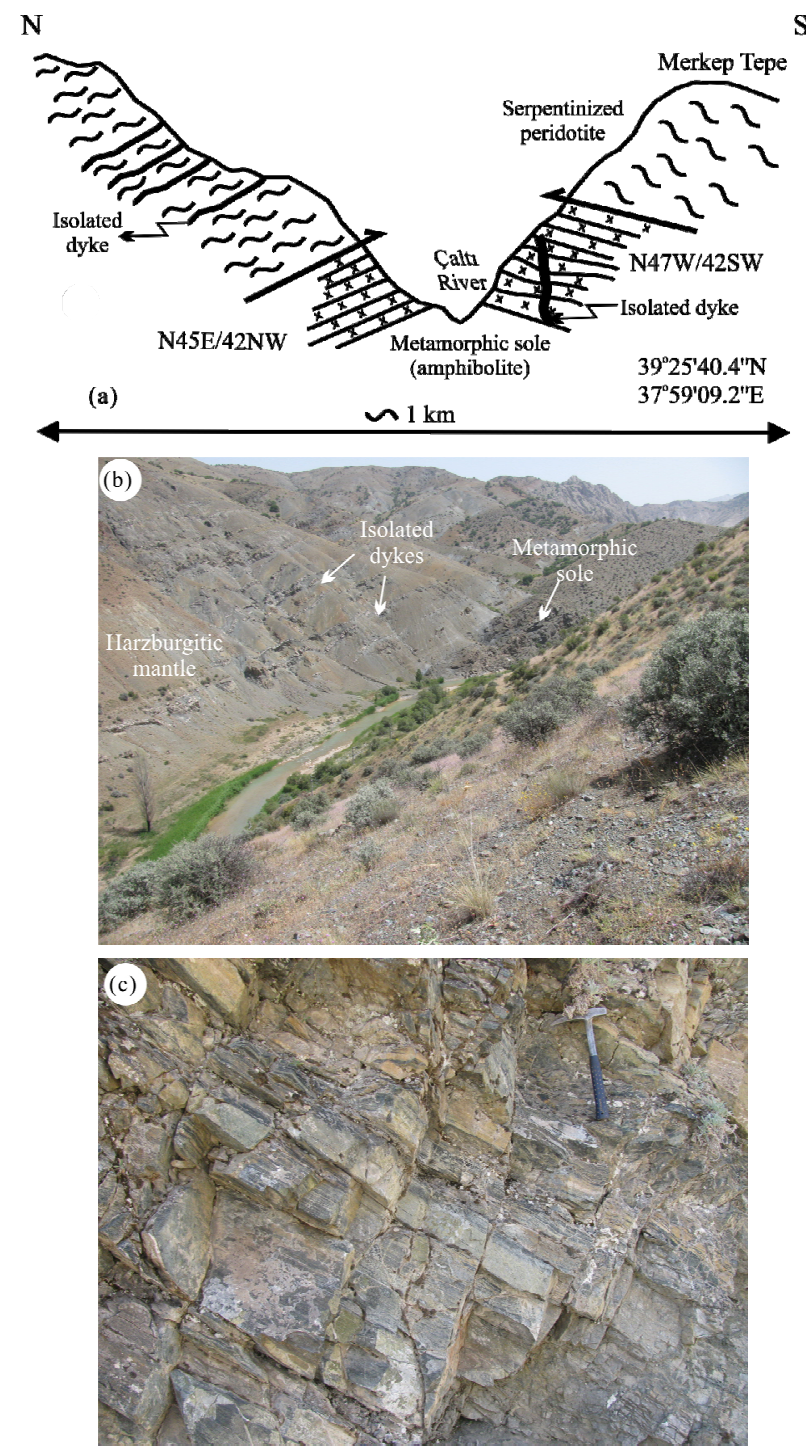

Figure 24. (a) Cross section showing the field relations of the mantle tectonite, metamorphic sole and the isolated dykes from the Divriği (Sivas) ophiolite. Field views of (b) mantle tectonites, isolated dykes and the metamorphic sole along the Çaltı River. (c) Close up view of foliated amphibolite. between the Mesozoic and Early Cenozoic (Robertson et al., 2012). These are, from north to south, the Intra-Pontide Ocean, the İzmir-Ankara-Erzincan Ocean (northern Neotethys), the Inner Tauride Ocean, the southern Neotethys and the Berit Ocean (Robertson et al., 2012, 2006; Parlak et al., 2009; Okay and Tüysüz, 1999; Görür et al., 1984; Robertson and Dixon, 1984; Şengör and Y1lmaz, 1981). With the exception of the Intra-Pontide Ocean, a widely accepted scenario for the evolution of the oceanic basins is: (a) Triassic rifting, (b) Jurassic-Early Cretaceous passive margin subsidence, (c) Late Cretaceous intraoceanic convergence/metamorphic sole formation/ supra-subduction zone ophiolite genesis and (d) latest Cretaceous emplacement onto continental margins.

The ophiolites along the Tauride belt were rooted to different oceanic basins namely the İzmir-Ankara-Erzincan Ocean, Inner Tauride Ocean and southern Neotethys. The Lycian nappes (Köyceğiz/Yeşilova ophiolites and associated mélanges) at the western end of Taurides are believed to have been derived from the northerly Neotethyan oceanic basin (Collins and Robertson, 1999, 1998, 1997). Mesozoic sedimentary rocks within the Lycian mélange are interpreted as rift and passive margin sequences, bordering the northerly strand of the Mesozoic Tethyan Ocean (Collins and Robertson, 1999). Similar rock assemblages have been reported to the north of the Menderes metamorphic massif in the Karaburun Peninsula (Erdoğan, 1990), from the İzmir-Ankara-Erzincan suture (Okay et al., 2012; Okay and Siyako, 1993; Poisson and Şahinci, 1988; Şahinci, 1976) and Chios Island (Greece) (Papanikolaou and Sideris, 1992). The Lycian nappes were emplaced southeastward onto the continental margin during the Late Cretaceous (Collins and Robertson, 1997). Southward re-thrusting of the Lycian nappes occured in the Late Eocene and finally ended in Late Miocene (Poisson, 1977). The Antalya complex, including the Tekirova ophiolite, has been correlated with the Troodos ophiolite (Cyprus), the Baer-Bassit ophiolite (northern Syria) and the Kızıldağ (Hatay) ophiolite. These ophiolites originated within the southern Neotethys (Çetinkaplan et al., 2016; Robertson et al., 2012; Robertson and Waldron, 1990; Robertson and Woodcock, 1982, 1981a, b, c). The Beyşehir-Hoyran nappes farther east originated near the southern margin of the Inner Tauride Ocean and reached their position by out-of-sequence thrusting in the Late Cretaceous (Andrew and Robertson, 2002). In the Late Eocene, during final closure of the oceanic basin, part of the northern margin of the Tauride carbonate platform was detached and thrust southwards, forming the regionally extensive Hadim nappe (Monod, 1977). The Mersin ophiolite and associated units exhibit many similarities to the Beyşehir-Hoyran nappes farther northwest and this suggests that they formed in the Inner Tauride Ocean and were emplaced to the north of the Tauride carbonate platform (Parlak and Robertson, 2004). The Late Eocene rethrusting did not affect the Mersin ophiolite. Both the northern and southern margins of the Bolkar Dağ carbonate platform are unconformably overlain by undeformed 
Maastrichtian to Early Tertiary transgressive units (Clark and Robertson, 2002; Avşar, 1992; Demirtaşlı et al., 1984). The northern margin of the Bolkar Dağ was affected by thrusting and folding in Late Eocene time (Clark and Robertson, 2002), but there is no evidence of Late Eocene compression affecting the Mersin ophiolite and related units farther south (Parlak and Robertson, 2004). The Pozant1Karsant1 and Alihoca ophiolites were rooted in the Inner Tauride Ocean that evolved between the Kırşehir massif to the north and the Tauride Platform to the south (Dilek et al., 1999; Dilek and Whitney, 1997; Polat et al., 1996; Lytwyn and Casey, 1995). The SSZ-type ophiolite and related units were emplaced southwards onto the Tauride Platform (Polat and Casey, 1995). The oldest units unconformably covering the ophiolite range in age from Maastrichtian to Early Paleocene (Clark and Robertson, 2002; Demirtaşlı et al., 1984), suggesting that the emplacement of the allochthonous rocks was completed in the latest Cretaceous time. The Pınarbaşı (Kayseri) and the Divriği (Sivas) ophiolites formed by spreading above a northward-dipping, intra-oceanic subduction zone within the Inner Tauride Ocean and were emplaced onto the East Tauride Platform as a result of trench-margin collision during the latest Cretaceous (Robertson et al., 2013; Parlak et al., 2006; Vergili and Parlak, 2005). Collision-related southward rethrusting in the Mid-Eocene strongly affected the Pınarbaş1 (Kayseri) ophiolite and related units, whereas the Divriği (Sivas) region experienced only folding.

Tectonic models for suprasubduction zone (SSZ) ophiolite genesis attribute it to subduction initiation. Fracture zones separating oceanic lithosphere of different ages and densities are the most plausible sites for subduction initiation (Stern and Bloomer, 1992; Casey and Dewey, 1984; Hawkins et al., 1984; Leitch, 1984). The initiation of subduction starts in response to convergence due to major plate re-organizations (Shervais, 2001; Casey and Dewey, 1984; Hawkins et al., 1984). Stern and Bloomer (1992) suggested that old dense lithosphere sinking into the asthenosphere rolls back and leaves a gap that is filled by rapid spreading at the leading edge of the lithosphere in the upper plate. Crustal formation is fed by melts from hot asthenosphere that must flow upward into the region above the sinking plate margin (Stern and Bloomer, 1992). Decompression melting aided by fluids lowering the solidus leads to extensive melting of the shallow asthenospheric wedge, creating boninites (high-Mg andesites) and leaves refractory harburgitic mantle tectonites (Stern and Bloomer, 1992). Initiation of subduction and formation of metamorphic soles have been linked to the ophiolite emplacement process (Wakabayashi and Dilek, 2003; Hacker, 1991; Jameison, 1986, 1980; Williams and Smyth, 1973). The metamorphic soles exhibit inverted metamorphic field gradients, from upper amphibolite facies directly beneath mantle tectonites to greenschist facies close to the mélange contact. The inverted temperature gradient responsible for the high-grade metamorphism of the sole decays quickly ( $\sim 2 \mathrm{Ma})$ as subduction continues (Hacker et al., 1996; Hacker, 1991,
1990; Peacock, 1988). The high-grade metamorphism of the metamorphic sole can occur only at the inception of subduction because the hanging wall would subsequently be too cold to cause high-grade metamorphism (Wakabayashi and Dilek, 2003). Temporal and spatial relations of ophiolites and metamorphic soles have been well-documented in the Oman ophiolite by high-precision $\mathrm{U}-\mathrm{Pb}$ zircon geochronology and whole rock Nd-isotopic data (Rioux et al., 2013; Warren et al., 2005). Warren et al. (2005) reported coeval $\mathrm{U}-\mathrm{Pb}$ zircon ages for trondhjemites $(95.3 \pm 0.2 \mathrm{Ma})$ and for amphibolites $(94.48 \pm 0.23 \mathrm{Ma})$, and suggested an SSZ origin for the Semail ophiolite. However, Rioux et al. (2013) provided more detailed U-Pb zircon ages and whole rock $\mathrm{Nd}$ isotopic data for the crustal rocks and the underlying metamorphic sole and concluded that most of the ophiolitic crust formed at an oceanic spreading center in $<1 \mathrm{Ma}$ in the Late Cretaceous, followed by subduction or thrusting that was established below the ophiolite after $\leq 0.25-0.5 \mathrm{Ma}$. Both mid-ocean ridge (MOR) and suprasubduction zone (SSZ) models have been proposed for the genesis of the Oman ophiolite (Rioux et al., 2013). MOR- and SSZ-type mantle residues have been reported from mantle tectonites of the Tauride ophiolites, suggesting a low-degree of partial melting in a mid-ocean ridge environment during the opening stage of the Neotethyan oceanic basins followed by re-melting and depletion in a suprasubduction zone (SSZ) setting (Saka et al., 2014; Uysal et al., 2012; Caran et al., 2010; Aldanmaz et al., 2009). All the evidence suggests that MOR-type oceanic lithosphere generation was overprinted by SSZtype oceanic lithosphere, that emplaced onto continental margins, after subduction initiation in response to convergence.

The Tethyan ophiolites along the Tauride belt attest to a series of tectonic events related to their genesis and emplacement: (1) initiation of intraoceanic subduction and metamorphic sole formation, (2) subduction roll-back and exhumation of metamorphic soles related to the ophiolite, (3) dyke emplacement through the metamorphic sole and ophiolite, (4) formation of subduction-accretion complexes (ophiolitic mélanges) and (5) thrusting of the SSZ-type ophiolite over continental margins by collision of arc-trench systems with passive margins. The crystallization ages of SSZ-type crust for the Tauride belt ophiolites are based on zircon U-Pb dating and constrained at $\sim 90 \mathrm{Ma}$. However magmatic activity continued prior to ophiolites emplacement (Parlak et al., 2013). On the other hand, timing of subduction initiation (metamorphic sole formation) and subsequent dyke emplacement are tightly constrained. The ${ }^{40} \mathrm{Ar} /{ }^{39} \mathrm{Ar}$ ages for hornblendes of the metamorphic soles range from 96 to $90 \mathrm{Ma}$ (Parlak et al., 2013; Çelik et al., 2006; Dilek et al., 1999; Parlak and Delaloye, 1999) and dyke emplacement ages range from 91 to $86 \mathrm{Ma}$ (Dilek et al., 1999; Parlak and Delaloye, 1996). This evidence suggests that the metamorphic soles and the isolated dykes did not experience any later tectonic effects such as remelting and metamorphism because they have yielded constant well-constrained plateau ages (Çelik et al., 2006; 
Dilek et al., 1999; Parlak and Delaloye, 1999, 1996). These age constraints and the crosscutting relations indicate that the formation of the metamorphic soles and dyke emplacement throughout the entire Tauride belt spanned 23 Ma (Dilek et al., 1999; Parlak and Delaloye, 1999).

Emplacement of ophiolites over passive continental margin of the Tauride-Anatolide Block has been well established in the Tavşanlı area in western Anatolia (Plunder et al., 2015; Okay and Whitney, 2010). The Tavşanlı zone is interpreted as the north-facing passive continental margin of the Anatolide-Tauride Block subducted below an oceanic plate during the Late Cretaceous (Okay et al., 1998; Önen and Hall, 1993; Okay, 1986). High temperature (HT) metamorphic sole rocks beneath the peridotite had a HP-LT overprint (Önen and Hall, 2000; Okay et al., 1998) and yielded ${ }^{40} \mathrm{Ar}-{ }^{39} \mathrm{Ar}$ cooling ages of $93.0 \pm 2$ and $90.0 \pm 3 \mathrm{Ma}$ in the Kütahya region (Önen, 2003). Continental margin units of the Tavşanlı zone have experienced HP/LT metamorphism ( 24 kbar/430-500 $\left.{ }^{\circ} \mathrm{C}\right)$ during the Late Cretaceous ( $\sim 80 \mathrm{Ma}$ ) (Plunder et al., 2013; Okay, 2002; Sherlock et al., 1999; Okay and Kelley, 1994). A relatively short time span $(\sim 15 \mathrm{Ma})$ is implied during ophiolite emplacement between intra-oceanic subduction and continental subduction (Plunder et al., 2015; Okay and Whitney, 2010).

Ophiolitic mélanges beneath the ophiolites are interpreted as remnants of Neotethyan oceanic lithosphere, deep-sea sediments, volcanic seamounts, rift-related and platform units that were emplaced by a combination of tectonic and sedimentary processes (Robertson et al., 2009). Geochemistry of volcanic rocks within the mélange indicates the presence of different magma types such as ocean island basalts (OIB), mid-ocean ridge basalts (MORB) and island arc basalts (IAB) (Parlak and Robertson, 2004; Andrew and Robertson, 2002; Collins and Robertson, 1998, 1997). Radiolarian cherts within the mélange units have yielded Late Triassic, Jurassic, Early Cretaceous and Late Cretaceous ages (Göncüoğlu et al., 2006; Parlak and Robertson, 2004; Tekin et al., 2002; Bragin and Tekin, 1996). The ophiolitic mélanges formed as oceanic accretionary complexes ahead of an advancing suprasubduction oceanic slab during the Late Cretaceous. Moreover, the Campanian-Maastrichtian mélanges beneath the Tethyan ophiolite complexes and the Late Maastrichtian or Paleocene-Early Eocene local cover sediments (Robertson et al., 2009; Demirtaşlı et al., 1984) clearly indicate that the emplacement of ophiolites occurred shortly after initiation of intra-oceanic subduction. All the data available favor a relatively narrow seaway (the Inner Tauride Ocean) for the genesis and emplacement of the SSZ-type ophiolites along the Tauride belt (Robertson et al., 2009; Dilek et al., 1999).

The ophiolites along the Tauride-Anatolide Platform in southern Turkey exhibit a number of similarities in terms of lithological, geochemical, geochronological and structural features: (a) They are dominated by harzburgites and dunites in mantle sections, (b) the mantle rocks are tectonically underlain by metamorphic soles, (c) both the mantle tectonites and metamorphic soles are cut by numerous diabase dykes aged close to $90 \mathrm{Ma}$, (d) their tectonostratigraphical sequences are similar (i.e. melangé, metamorphic sole and ophiolite), (e) the subophiolitic metamorphic rocks yield constant isotopic ages ( $92 \mathrm{Ma})$, (f) the subophiolite metamorphic rocks display HT (hightemperature) metamorphism, except for the Kizıltepe ophiolite in the Bolkardag region where high-pressure metamorphism overprints earlier HT (high-temperature) metamorphism (Dilek and Whitney, 1997), (g) the upper crustal parts of the ophiolites (extrusives and sheeted dykes) along the Tauride Mountains were removed by tectonic processes, (h) cumulate rocks are generally well-preserved and exhibit subduction-related origin for their genesis. These common features suggest that although the ophiolites along the Tauride-Anatolide Block occur as relatively small bodies isolated due to later tectonism, these ophiolitic massifs may have formed part of a very large ophiolite thrust sheet obducted over the Tauride-Anatolide Block during the Late Cretaceous.

Many tectonic models have been proposed over the last two decades concerning the genesis of ophiolites, metamorphic soles, dyke intrusions, mélange formation and emplacement with respect to the Tauride belt ophiolites (Fig. 23) (Çelik and Chiaradia, 2008; Elitok and Drüppel, 2008; Çelik, 2007; Çelik and Delaloye, 2006; Parlak et al., 2006; Parlak and Robertson, 2004; Andrew and Robertson, 2002; Collins and Robertson, 1999, 1998, 1997; Dilek et al., 1999; Dilek and Whitney, 1997). In the present discussion the Tekirova (Antalya) ophiolite is excluded because it evolved within a small oceanic basin that was strongly influenced by strike-slip faulting during both the opening and closing stages of the southern Neotethys (Robertson and Woodcock, 1984). The models (Fig. 25) include: (a) A dualsubparallel oceanic spreading centers operating simultaneously accompanied by ridge-subduction (Polat et al., 1996; Lytwyn and Casey, 1995), (b) slab break-off (Çelik, 2007; Parlak et al., 2006), (c) multiple intra-oceanic thrusting and emplacement events (Çelik and Chiaradia, 2008; Çelik, 2007), (d) asymmetrical ridge collapse (Dilek et al., 1999) and (e) steady-state subduction (Parlak and Robertson, 2004). In all models, it is difficult to explain the exhumation of the metamorphic soles relative to overlying ophiolites and post-metamorphic dyke emplacement into the metamorphic soles and ophiolites because there is a space problem for the sites of the metamorphic soles and melts that contributed to accretion of SSZ-type oceanic lithosphere. Robertson (2004) has discussed many of the problems related to the spatial and temporal relations of the metamorphic soles and dykes and their emplacement during genesis of the SSZ-type ophiolites in the eastern Mediterranean region.

Available ${ }^{40} \mathrm{Ar} /{ }^{39} \mathrm{Ar}$ ages on the metamorphic soles and post-metamorphic isolated dykes, as well as zircon $\mathrm{U}-\mathrm{Pb}$ ages on the crustal rocks of the Tauride ophiolites, suggest the following evolutionary scenario displayed in Fig. 26. (a) Subduction initiation began within the Inner Tauride Ocean in Late Cretaceous times along a fracture zone rather than at 

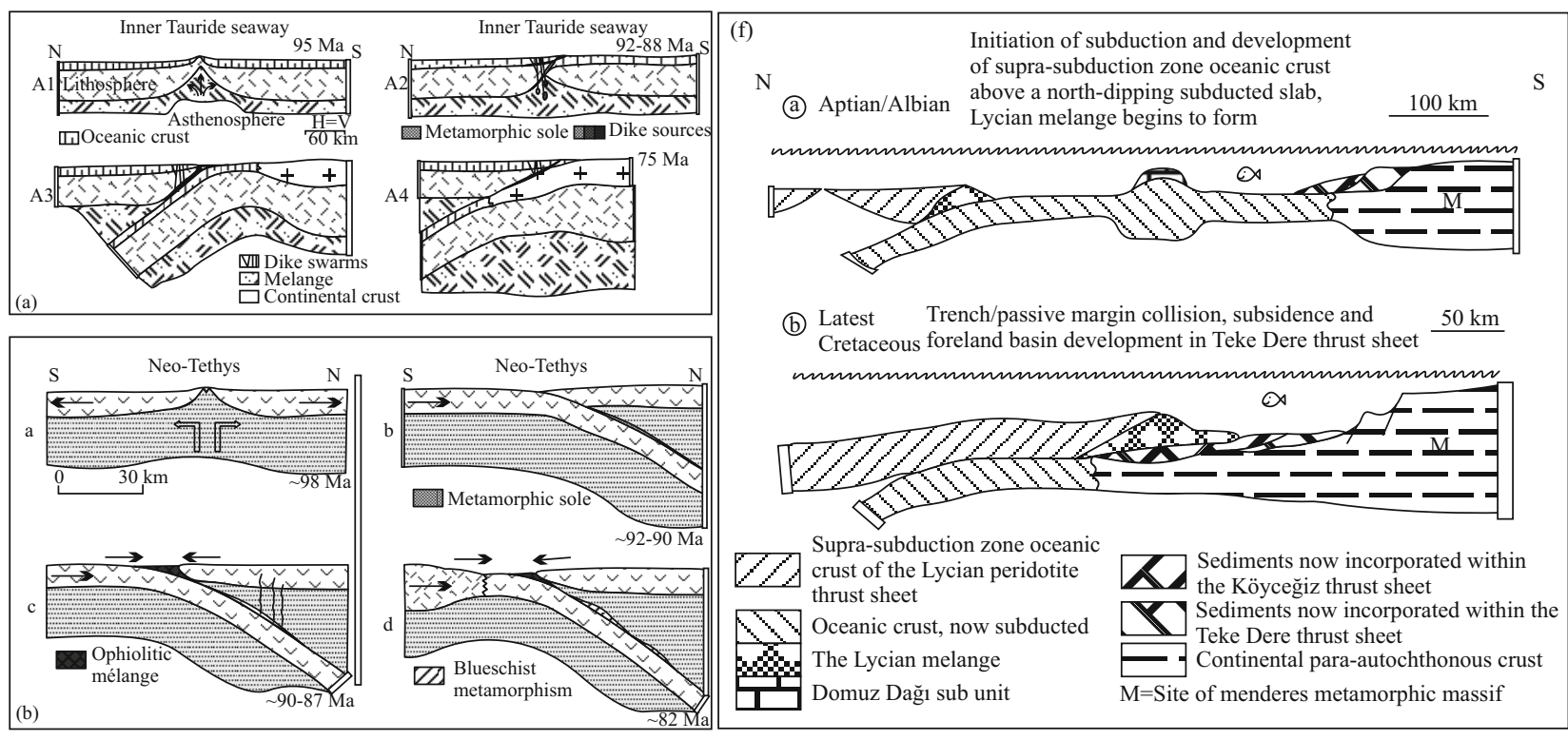

Cretaceous foreland basin development in Teke Dere thrust sheet
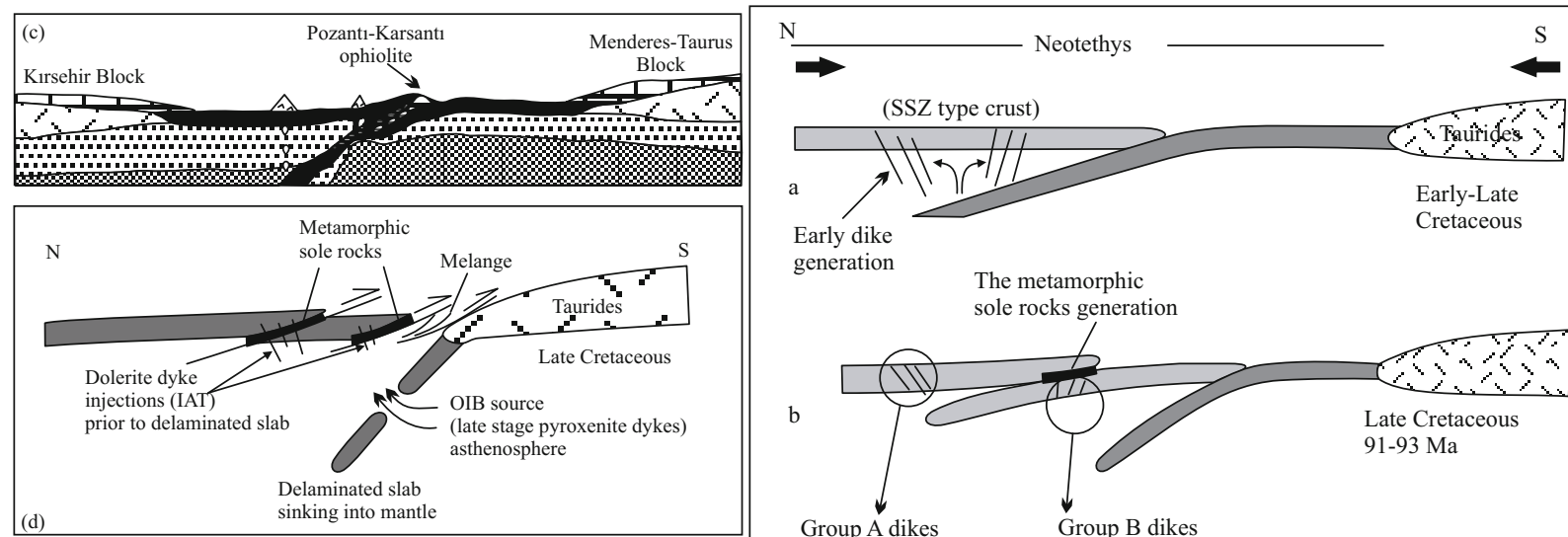

generation

The metamorphic

sole rocks generation
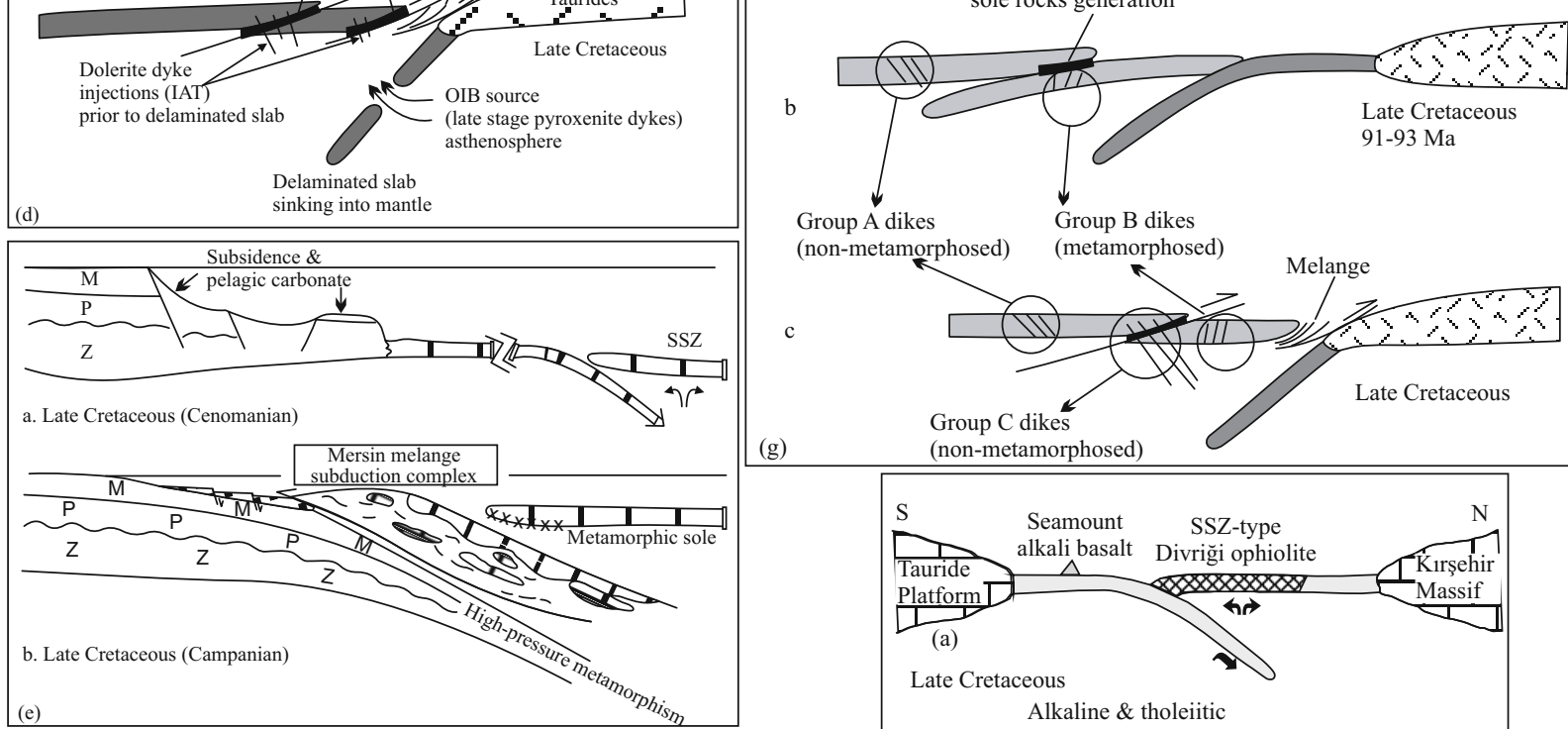

(non-metamorphosed)

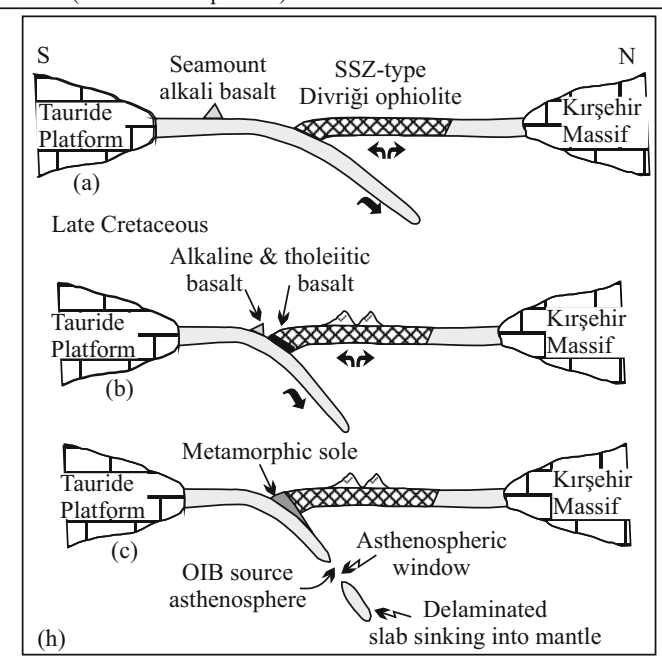

Figure 25. Tectonic models proposed for the genesis of the Tauride ophiolites, their metamorphic soles and dyke emplacement. (a) (Dilek et al., 1999), (b) Dilek and Whitney (1997), (c) Lytwyn and Casey (1995), (d) Çelik (2007), (e) Parlak and Robertson (2004), (f) Collins and Robertson (1999), (g) Çelik and Chiaradia (2008), (h) Parlak et al. (2006), (i) Çelik and Delaloye (2006). 


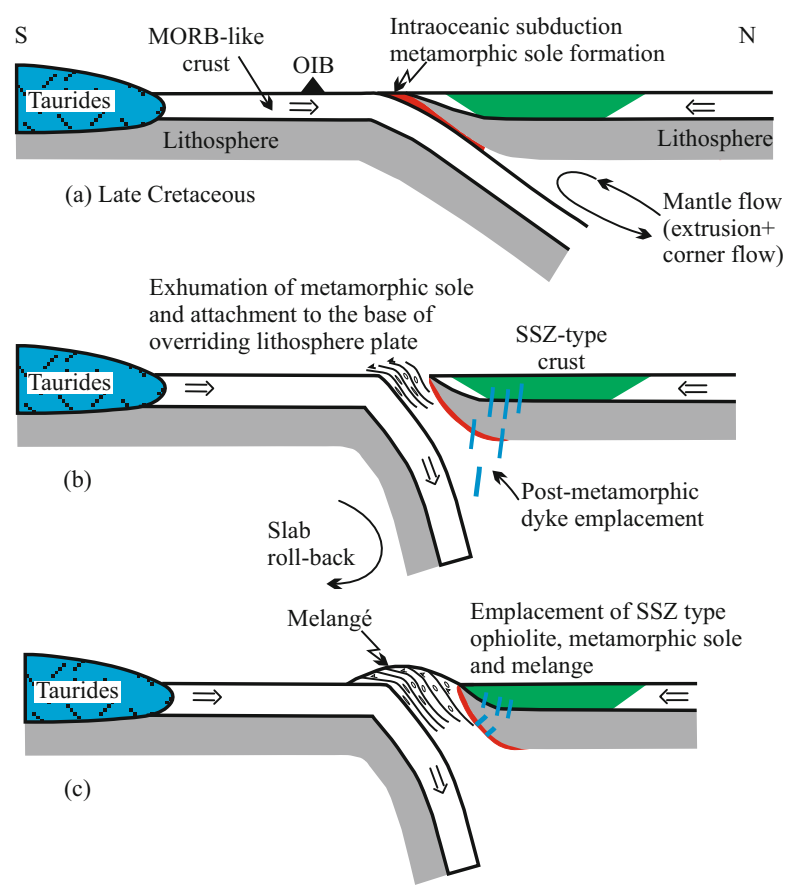

Figure 26. Proposed tectonic model for the genesis of the ophiolites, metamorphic soles and subsequent dyke emplacement in the Tauride belt.

an active spreading ridge because the protoliths of the metamorphic sole rocks have different compositions from lavas in the upper part of the overriding ophiolite (Parlak et al., 1995a). During subduction initiation, mainly OIB-like alkaline and MORB-type tholeiitic basalts were accreted to the base of the overriding oceanic plate and metamorphosed under amphibolite facies conditions at about 96-90 Ma. (b) Following subduction initiation and metamorphic sole formation, old dense lithosphere sank into the asthenosphere rolled back, allowing the metamorphic sole to be rapidly exhumed and attached to the base of the overriding plate. The roll back process left a gap that was filled by rapid spreading at the leading edge of the overriding plate. (c) Hot asthenosphere upwelled into the region above the sinking plate margin. (d) Decompression and fluids from the subducted slab lowered the solidus of the mantle wedge, creating extensive melting of the shallow asthenosphere. Crustal formation was fed by melts, including both boninitic (high-Mg andesites) and island arc tholeiitic magmas, leaving a refractory tectonized harburgitic mantle (Stern and Bloomer, 1992). (e) After 2-3 Ma, isolated post-metamorphic dykes exhibiting IAT geochemical affinity intruded the metamorphic sole and the overlying oceanic lithosphere at 91-86 Ma. (f) Late stage dykes with enriched compositions are interpreted as having been derived from local fractures or tears in the subducting plate rather than large-scale break off because slab break off would produce much greater volumes of enriched magma than that contained in these late-stage isolated dikes. The isolated dykes cut the primary tectonic contact between the metamorphic sole and the harzburgitic mantle tectonites in the Köyceğiz and Pozantı-Karsantı areas, which is interpreted as a primary intraoceanic decoupling surface along which the volcanics on the top of the down-going slab were metamorphosed up to the amphibolite facies and attached to the base of the hanging wall plate. Isolated dykes are not observed in the ophiolitic mélange, suggesting they were intruded prior to mélange formation and subsequent ophiolite emplacement onto the Tauride Platform.

Different cooling histories of the metamorphic soles and oceanic crustal rocks, as well as different blocking temperatures of zircon $\mathrm{U}-\mathrm{Pb}\left(\sim 900{ }^{\circ} \mathrm{C}\right)$ and hornblende ${ }^{40} \mathrm{Ar} /{ }^{39} \mathrm{Ar}\left(\sim 550{ }^{\circ} \mathrm{C}\right)$ systems, do not permit compilation of a coherent geochronological record (Hacker and Gnos, 1997; Spray, 1984). Therefore, more high-precision U-Pb geochronological studies on zircons in both magmatic and metamorphic rocks of the Tauride belt ophiolites should be applied to better constrain the temporal relations of the oceanic lithosphere and the metamorphic soles, as has been done in the Oman ophiolite (Rioux et al., 2013; Warren et al., 2005).

\section{CONCLUSIONS}

(a) The Tauride belt ophiolites (Lycian nappes, Tekirova-Antalya, Beyşehir-Hoyran nappes, Mersin, Alihoca, Pozantı-Karsantı, Pınarbaşı and Divriği) are situated either on the northern or the southern flank of the E-W trending Tauride carbonate platform axis.

(b) The Tauride belt ophiolites were generated above an intra-oceanic subduction zone and emplaced in the Late Cretaceous times over the Tauride carbonate platform from different Neotethyan oceanic basins.

(c) The Tauride ophiolites are underlain by wellpreserved metamorphic soles that have a constant structural position between ophiolitic mélange below and harzburgitic mantle tectonites above. The dynamothermal metamorphic soles display a typical inverted metamorphic sequence, grading from amphibolite facies directly beneath the highly sheared harzburgitic tectonite to greenschist facies close to the mélange contact. They display variable structural thicknesses up to $500 \mathrm{~m}$. The metamorphic soles beneath the Tauride ophiolites are interpreted as relating to the initiation of subduction and emplacement processes.

(d) The inverted metamorphic gradients of metamorphic soles beneath the Tauride ophiolites imply very rapid exhumation shorthly after their formation.

(e) The geochemistry of the metamorphic sole amphibolites suggests magma derivation from different geochemical environments; such as seamount-type alkaline basalts, mid-ocean ridge basalt (MORB) and island arc basalts.

(f) The contact between the metamorphic sole and the overlying serpentinized harzburgites in the Köycegiz and Pozant1-Karsant1 regions is characterized by a $1.5-2-\mathrm{m}$-thick zone of sheared serpentinized harzburgitic mantle tectonites intercalated with amphibolites. These lithologies are cut by thick mafic dykes (individually $7-8 \mathrm{~m}$ thick), which postdate intraoceanic metamorphism and high-temperature ductile deformation. This contact is interpreted as an intra-oceanic decoupling surface along which volcanics in the upper levels of the down-going plate were metamorphosed to amphibolite facies and accreted to the base of the hanging wall plate.

(g) The metamorphic soles and their overlying ophiolitic 
rocks are intruded by numerous isolated post-metamorphic diabase dykes mainly derived from island arc tholeitic magmas.

(h) The Tauride belt ophiolites were first emplaced southward in the latest Cretaceous onto the Tauride-Anatolide continental margin. Late Eocene and Miocene re-thrusting related to suture tightening also occured in some regions.

(i) Subduction initiation and roll-back processes in the Late Cretaceous can best explain the structural and petrological relationships of ophiolite genesis, metamorphic sole formation and subsequent dyke emplacement for the Tauride belt ophiolites.

\section{ACKNOWLEDGMENTS}

Michel Delaloye, Alastair Robertson, Volker Höck and Friedrich Koller are thanked for discussions on Tethyan ophiolites. I particularly thank present and former PhD (Utku Bağc1, Tamer Rızaoğlu, Fatih Karaoğlan, Nail Yıldırım, Cahit Dönmez, Nusret Nurlu, Güzide Önal and Evren Arslan) and MSc (Özden Vergili, Aydın Çolakoğlu, Selena Ezgi Öztürk, Emrah Şimşek, Gökçe Şimşek, Tuğba Daşçı and Mehmet Baydan) students for dicussions of different aspects at one time or another. Çukurova University Research Foundation (Nos. MMF99.22, MMF2000.22, MMF2001.13, MMF2001.33, MMF2002BAP41, MMF2003BAP16, MMF2011BAP13, and MMF2011BAP26), Turkish Academy of Sciences (No. TÜBA-GEBIP/2003-111), TÜBİTAK (Nos. 199Y011, 102Y041, 106Y231, and 113Y412), DARIUS program and MTA are acknowledged for financial support over many years. The manuscript benefitted from comments by Paul Robinson, Aral İ. Okay and the editor Timothy M. Kusky. The final publication is available at Springer via http://dx.doi.org/10.1007/s12583-0160679-3.

Open Access This article is distributed under the terms of the Creative Commons Attribution 4.0 International License (http://creativecommons.org/licenses/by/4.0/), which permits unrestricted use, distribution, and reproduction in any medium, provided you give appropriate credit to the original author and the source, provide a link to the Creative Commons license, and indicate if changes were made.

\section{REFERENCES CITED}

Aldanmaz, E., Schmidt, M. W., Gourgaud, A., et al., 2009. MidOcean Ridge and Supra-Subduction Geochemical Signatures in Spinel-Peridotites from the Neotethyan Ophiolites in SW Turkey: Implications for Upper Mantle Melting Processes. Lithos, 113: 691-708

Andrew, T., Robertson, A. H. F., 2002. The Beyşehir-HoyranHadim Nappes: Genesis and Emplacement of Mesozoic Marginal and Oceanic Units of the Northern Neotethys in Southern Turkey. The Journal of the Geological Society, 159: 529-543

Avşar, N., 1992. Palaeogene Benthic Foraminifera Fauna of the Namrun (İçel) Region. Maden Tetkik ve Arama Dergisi, 114: 127-144 (in Turkish with English Abstract)

Bağc1, U., Parlak, O., 2009. Petrology of the Tekirova (Antalya)
Ophiolite (Southern Turkey): Evidence for Diverse Magma Generations and Their Tectonic Implications during Neotethyan-Subduction. International Journal of Earth Sciences, 98: 387-405

Bağc1, U., Parlak, O., Höck, V., 2006. Geochemical Character and Tectonic Environment of Ultramafic to Mafic Cumulates from the Tekirova (Antalya) Ophiolite (Southern Turkey). Geological Journal, 41: 193-219

Beccaletto, L., Jenny, C., 2004. Geology and Correlation of the Ezine Zone: A Rhodope Fragment in NW Turkey? Turkish Journal of Earth Sciences, 13: 145-176

Bingöl, A. F., 1978. Petrologie du Massif Ophiolitique de Pozanti-Karsanti (Taurus Cilicien, Turquie): Etude de la Partie Orientale: [Dissertation]. University of Strasbourg, Strasbourg

Bingöl, A. F., Juteau, T., 1977. Mise en Evidence d'une Discordance Entre Tectonites et Cumulats Dans le Massif Ophiolitique de Karsantı (Chaine du Taurus, Turquie). 5e Reunion ann. Sci. Terre, Rennes. 76

Blumenthal, M., 1947. Belemedik Palaeozoic Window and Its Mesozoic Calcerous Frame. Maden Tetkik ve Arama Enstitüsü Yayınlarl, D3: 1-93 (in Turkish with English Abstarct)

Blumenthal, M., 1955. Geologie des Holen Bolkardağ Seiner Nordlicher Rondgebiete und Westlichen Auslaufer. Maden Tetkik ve Arama Enstitüsü Yayınlarl, Ankara, D7: 1-169

Boztuğ, D., Harlavan, Y., Arehart, G. B., et al., 2007. K-Ar Age, Whole Rock and Isotope Geochemistry of A-Type Granitoids in the Divrigi-Sivas Region, Eastern-Central Anatolia, Turkey. Lithos, 97: 193-218

Bragin, N. Y., Tekin, U. K., 1996. Age of Radiolarian Chert Blocks from the Senonian Ophiolitic Mélange (Ankara, Turkey). Island Arc, 5: 114-122

Brunn, J. H., De Graciansky, P. C., Gutnic, M., et al., 1970. Structures Majeures et Corre'Lations Stratigraphiques Dans les Taurides Occidentales. Bulletin de La Societe Geologique de France, 12: 515-556

Brunn, J. H., Dumont, J. F., De Graciansky, P. C., et al., 1971. Outline of the Geology of the Western Taurides. In: Campbell, A. S., ed., Geology and History of Turkey. Petroleum Exploration Society of Libya, Tripoli. 225-255

Çakır, Ü., 1978. Petrologie du Massif Ophiolitique de PozantıKarsanti (Taurus Cilicien, Turquie): Etude de La Partie Centrale: [Dissertation]. University of Louis Pasteur, Louis Pasteur

Çakır, Ü., Juteau, T., Whitechurch, H., 1978. New Evidence for Early Intraoceanic Slicing of Tethyan Ophiolites: Metamorphic Sole Rocks beneath the Pozant1-Karsant1 Ophiolite (Turkey). Bulletin de la Societe Geologique de France, 1: 61-70

Caran, Ş., Çoban, H., Flower, M. F. J., et al., 2010. Podiform Chromitites and Mantle Peridotites of the Antalya Ophiolite, Isparta Angle (SW Turkey): Implications for Partial Melting and Melt-Rock Interaction in Oceanic and SubductionRelated Settings. Lithos, 114: 307-326

Casey, J. F., Dewey, J. F., 1984. Initiation of Subduction Zones. In: Gass, I. G., Lippard, S. J., Shelton, A. W., eds., Ophiolites and Oceanic Lithosphere. Geological Society, London, Special Publications, 13: 269-290 
Çatakl1, A. Ş., 1983. Assemblage Ophiolitique et Roches Associees de la Partie Occidentale du Massif de Pozant1Karsanti (Taurus Cilicien, Turquie): [Dissertation]. University of Nancy, Nancy

Çelik Ö. F., Delaloye, M., 2003. Origin of Metamorphic Soles and Their Post-Kinematic Mafic Dyke Swarms in the Antalya and Lycian Ophiolites, SW Turkey. Geological Journal, 38: 235-256

Çelik, Ö. F., 2002. Geochemical, Petrological and Geochronological Observations on the Metamorphic Rocks of the Tauride Belt Ophiolites (S. Turkey): [Dissertation]. University of Geneva, Switzerland

Çelik, Ö. F., 2007. Metamorphic Sole Rocks and Their Mafic Dykes in the Eastern Tauride Belt Ophiolites (Southern Turkey): İmplications for OIB Type Magma Generation Following Slab Break-off. Geological Magazine, 144: 849866

Çelik, Ö. F., 2008. Detailed Geochemistry and K-Ar Geochronology of the Metamorphic Sole Rocks and Their Mafic Dykes from the Mersin Ophiolite, Southern Turkey. Turkish Journal of Earth Sciences, 17: 685-708

Çelik, Ö. F., Chiaradia, M., 2008. Geochemical and Petrological Aspects of Dyke İntrusions in the Lycian Ophiolites (SW Turkey): A Case Study for the Dyke Emplacement along the Tauride Belt Ophiolites. International Journal of Earth Sciences, 97: 1151-1164

Çelik, Ö. F., Delaloye, M., 2006. Characteristics of OphioliteRelated Metamorphic Rocks in the Beyşehir Ophiolitic Mélange (Central Taurides, Turkey), Deduced from Whole Rock and Mineral Chemistry. Journal of Asian Earth Sciences, 26: 461-476

Çelik, Ö. F., Delaloye, M., Feraud, G., 2006. Precise ${ }^{40} \mathrm{Ar}^{39} \mathrm{Ar}$ Ages from the Metamorphic Sole Rocks of the Tauride Belt Ophiolites, Southern Turkey: İmplications for the Rapid Cooling History. Geological Magazine, 143: 213-227

Çelik, Ö. F., Marzoli, A., Marschik, R., et al., 2011. EarlyMiddle Jurassic Intra-Oceanic Subduction in the İzmirAnkara-Erzincan Ocean, Northern Turkey. Tectonophysics, 509: 120-134

Çetinkaplan, M., Pourteau, A., Candan, O., et al., 2016. P-T-t Evolution of Eclogite/Blueschist Facies Metamorphism in Alanya Massif: Time and Space Relations with HP Event in Bitlis Massif, Turkey. International Journal of Earth Sciences, 105: 247-281

Chan, G. H. N., Malpas, J., Xenophontos, C., et al., 2007. Timing of Subduction Zone Metamorphism during the Formation and Emplacement of Troodos and Baër-Bassit Ophiolites: Insights from ${ }^{40} \mathrm{Ar}-{ }^{39} \mathrm{Ar}$ geochronology. Geological Magazine, 144: 797-810

Clark, M., Robertson, A. H. F., 2002. The Role of the Early Tertiary Uluk1s, la Basin, Southern Turkey, in Suturing of the Mesozoic Tethys Ocean. The Journal of the Geological Society, London, 159: 673-90

Collins, A. S., Robertson, A. H. F., 1997. Lycian Mélange, Southwestern Turkey: An Emplaced Late Cretaceous Accretionary Complex. Geology, 25: 255-258

Collins, A. S., Robertson, A. H. F., 1998. Processes of Late Cretaceous to Late Miocene Episodic Thrust Sheet Transla- tion in the Lycian Taurides, SW Turkey. The Journal of the Geological Society, London, 155: 759-772

Collins, A. S., Robertson, A. H. F., 1999. Evolution of the Lycian Allochthon, Western Turkey, as a North-Facing Late Palaeozoic to Mesozoic Rift and Passive Continental Margin. Geological Journal, 34: 107-138

Daşçı, H. T., Parlak, O., Nurlu, N., et al., 2015. Geochemical Characteristics and Age of Metamorphic Sole Rocks within a Neotethyan Ophiolitic méLange from Konya Region (Central Southern Turkey). Geodinamica Acta, 27: 223-243

De Graciansky, P. C., 1972. Recherches Géologiques Dans le Taurus Lycien: [Dissertation]. Université de Paris-Sud (Orsay), France

Delaune-Mayere, M., Marcoux, J., Parrot, J. F., et al., 1977. Modele d'Evolution Mesozoique de La Paleomarge Tethysienne au Niveau Des Nappes Radiolaritiques et Ophiolitiques du Taurus Lycien, d'Antalya et du Baer-Bassit. In: Biju-Duval, B., Montadert, L., eds., International Symposium on the Structural History of the Mediterranean Basin, Split, Octobre 25-29, 1976, Technip, Paris. 79-94

Demirtaşl1, E., Turhan, N., Bilgin, A. Z., et al., 1984. Geology of the Bolkar Mountains. In: Tekeli, O., Göncüoğlu, M. C., eds., Geology of the Taurus Belt. Proceedings of International Symposium on the Geology of the Taurus Belt, Mineral Resources and Exploration Institute of Turkey, Ankara, Turkey. 12-141

Dilek, Y., Flower, M. F. J., 2003. Arc-Trench Rollback and Forearc Accretion: 2. A Model Template for Ophiolites in Albania, Cyprus, and Oman. In: Dilek, Y., Robinson, P. T., eds., Ophiolites in Earth History. Geological Society, London, Special Publication, 218: 43-68

Dilek, Y., Thy, P., Hacker, B. R., et al., 1999. Structure and Petrology of Tauride Ophiolites and Mafic Dyke İntrusions (Turkey): İmplications for the Neotethyan Ocean. Geological Society of America, 111: 1192-1216

Dilek, Y., Whitney, D. L., 1997. Counterclockwise $P-T-t$ Trajectory from the Metamorphic Sole of a Neotethyan Ophiolites (Turkey). Tectonophysics, 280: 295-310

Dimo-Lahitte, A., Monie, P., Vergely, P., 2001. Metamorphic Soles from the Albanian Ophiolites, Petrology, ${ }^{40} \mathrm{Ar} /{ }^{39} \mathrm{Ar}$ Geochronology, and Geodynamic Evolution. Tectonics, 20: 78-96

Elitok, Ö., 2001. Geochemistry and Tectonic Significance of the Şarkikaraağaç Ophiolites in the Beyşehir-Hoyran Nappes, SW Turkey. In: Akıncı, Ö., Görmüş, M., Kuşçu, M., et al., eds., Proceedings of the 4th International Symposium on Eastern Mediterranean Geology, May 21-25, 2001, Isparta, Turkey. 181-196

Elitok, Ö., Drüppel, K., 2008. Geochemistry and Tectonic Significance of Metamorphic Sole Rocks beneath the BeyşehirHoyran Ophiolite (SW-Turkey). Lithos, 100: 322-353

Erdoğan, B., 1990. Stratigraphy and Tectonic Evolution of the İzmir-Ankara Zone between Izmir and Ankara. Turkish Association of Petroleum Geologists Bulletin, 2: 1-20

Erkan, E. N., Özer, S., Sümengen, M., et al., 1978. General Geology of Sarız-Şarkışla-Gemerek-Tomarza. Maden Tetkik ve Arama Genel Müdürlüğü, Rapor No. 5646, Ankara (Unpublished Report) 
Göncüoğlu, M. C., Dirik, K., Kozlu H., 1996-1997. Pre-Alpine and Alpine Terranes in Turkey: Explanatory Notes to the Terrane Map of Turkey. Ann. Geol. Pays. Héll., 37: 1-3

Göncüoğlu, M. C., Yalınız, M. K., Tekin, U. K., 2006. Geochemistry, Tectono-Magmatic Discrimination and Radiolarian Ages of Basic Extrusives from the İzmirAnkara Suture Belt (NW Turkey): Time Constraints for the Neotethyan Evolution. Ofioliti, 31: 25-38

Görür, N., Oktay, F. Y., Seymen, İ., et al., 1984. Palaeotectonic Evolution of the Tuzgölü Basin Complex, Central Turkey: Sedimentary Record of a Neotethyan Closure. In: Dixon, J. A., Robertson, A. H. F., eds., The Geological Evolution of the Eastern Mediterranean. Geological Society of London, Special Publication, 17: 467-482

Hacker, B. R., 1990. Simulation of the Metamorphic and Deformational History of the Metamorphic Sole of the Oman Ophiolite. Journal of Geophysical Research, 95: 4895-4907

Hacker, B. R., 1991. The Role of Deformation in the Formation of Metamorphic Field Gradients: Ridge Subduction beneath the Oman Ophiolite. Tectonics, 10: 455-473

Hacker, B. R., Gnos, E., 1997. The Conundrum of Semail: Explaining the Metamorphic History. Tectonophysics, 279: 215-226

Hacker, B. R., Mosenfelder, J. L., Gnos, E., 1996. Rapid Emplacement of the Oman Ophiolite: Thermal and Geochronological Constraints. Tectonics, 15: 1230-1247

Harris, N. B. W., Kelley, S. P., Okay, A. I., 1994. Post-Collision Magmatism and Tectonics in northwest Turkey. Contributions to Mineralogy and Petrology, 117: 241-52

Hässig, M., Rolland, Y., Sosson, M., et al., 2011. New P-T-t Data on the Metamorphic Sole of the Amasia Ophiolites and Implications for the Geodynamic Process, NW of the Sevan-Akera Suture Zone, Lesser Caucasus (Armenia). Geophysical Research Abstract, 13: EGU2011-7462-1

Hawkins, J. W., Bloomer, S. H., Evans, C. A., et al., 1984. Evolution of İntra-Oceanic Arc-Trench Systems. Tectonophysics, 102: 175-205

Jameison, R. A. 1980. Formation of Metamorphic Aureoles beneath Ophiolites-Evidence from the St. Anthony Complex, Newfoundland. Geology, 8: 150-154

Jameison, R. A., 1986. P-T Paths from High Temperature Shear Zones beneath Ophiolites. Journal of Metamorphic Geology, 4: 3-22

Juteau, T., 1975. Les Ophiolites des Nappes d'Antalya (Tauride Occidentales, Turquie). Sciences de La Terre, Nancy, 15: 265-288

Juteau, T., 1980. Ophiolites of Turkey. Ofioliti, 2: 199-235

Juteau, T., Nicolas, A., Dubessy, J., et al., 1977. Structural Relationships in the Antalya Complex, Turkey: Possible Model for an Oceanic Ridge. Geological Society of America Bulletin, 88: 1740-1748

Juteau, T., Whitechurch, H., 1980. The Magmatic Cumulates of Antalya (Turkey): Evidence of Multiple Intrusions in an Ophiolitic Magma Chamber. In: Panayiotou, A., ed., Proceedings of International Ophiolite Symposium, Geological Survey, Cyprus. 377-391

Karaoğlan, F., Parlak, O., Hejl, E., et al., 2016. Temporal Evolu- tion of the Active Margin along the Southeast Anatolian Orogenic Belt (SE Turkey): Evidence from U-Pb, Ar-Ar and Fission Track Chronology. Gondwana Research, 33: 190-208

Kuşçu, İ., Gençalioğlu-Kuşçu, G., Tosdal, R. M., et al., 2010. Magmatism in the Southeastern Anatolian Orogenic Belt: Transition from Arc to Post-Collisional Setting in an Evolving Orogen. In: Sosson, M., Kaymakçı, N., Stephenson, R. A., et al., eds., Sedimentary Basin Tectonics from the Black Sea and Caucasus to the Arabian Platform. Geological Society, London, Special Publication, 340: 437-460

Leitch, E. C., 1984. Island Arc Elements and Arc Related Ophiolites. Tectonophysics, 106: 177-203

Lytwyn J. N., Casey, J. F., 1995. The Geochemistry of Postkinematic Mafic Dyke Swarms and Subophiolitic Metabasites, Pozanti-Karsanti Ophiolite, Turkey: Evidence for Ridge Subduction. Geological Society of America Bulletin, 107: 830-850

Marcoux, J., 1970. Age Carnien de Termes Effusifs du Cortege Ophiolitique Des Nappes d'Antalya (Taurus Lycien Occidental. Turquie). C. R. Acad. Sci. Fr., 271: 285-287

Marcoux, J., 1976. Les Series des Nappes a Radiolarites et Ophiolites d'Antalya (Turquie): Homologies et Signification Probable. Bulletin de La Societe Geologique de France, 2: 511-512

McCaig, A. M., 1983. P-T Conditions during Emplacement of the Bay of Islands Ophiolite Complex. Earth and Planetary Science Letters, 63: 459-473

Monod, O., 1977. Geological Investigations in Western Taurides to the South of Beyşehir (Turkey): [Dissertation]. University of Paris-Sud, Paris-Sud. 450

MTA, 2002. Geological Map of Turkey, 1 : 500 000. Maden Tektik ve Arama Genel Müdürlüğ̈̈, General Directorate of Mineral Research and Exploration, Ankara

Okay, A. İ., 1986. High-Pressure/Low-Temperature Metamorphic Rocks of Turkey. In: Evans, B. W., Brown, E. H., eds., Blueschists and Eclogites. Geological Society of America Memoir, 164: 333-348

Okay, A. İ., 1989. Alpine-Himalayan Blueschists. Annual Review of Earth and Planetary Sciences, 17: 55-87

Okay, A. İ., 2002. Jadeite-Chloritoid-Glaucophane-Lawsonite Blueschists in North-West Turkey: Unusually High P/T Ratios in Continental Crust. Journal of Metamorphic Geology, 20: 757-768

Okay, A. İ., Harris, N. B. W., Kelley, S., 1998. Exhumation of Blueschists along a Tethyan Suture in Northwest Turkey. Tectonophysics, 285: 275-299

Okay, A. İ., İşintek, İ., Altıner, D., et al., 2012. An OlistostromeMélange Belt Formed along a Suture: Bornova Flysch Zone Western Turkey. Tectonophysics, 568-569: 282-295

Okay, A. İ., Kelley, S., 1994. Tectonic Setting, Petrology and Geochronology of Jadeite+Glaucophane and Chloritoid+ Glaucophane Schsits from North-West Turkey. Journal of Metamorphic Geology, 12: 455-466

Okay, A. İ., Satır, M., Maluski, H., et al., 1996. Paleo- and NeoTethyan Events in Northwest Turkey: Geological and Geochronological Constraints. In: Yin, A., Harrison, M., eds., Tectonics of Asia. Cambridge University Press, Cam- 
bridge. $420-441$

Okay, A. İ., Siyako, M., 1993. The Position of the İzmir-Ankara Neo-Tethyan Suture between İzmir and Balıkesir. In: Turgut, S., ed., Tectonism and Hydrocarbon Potential of Anatolia. Proceedings of the Ozan Sungurlu Symposium, Ankara. 353-354

Okay, A. İ., Tüysüz, O., 1999. Tethyan Sutures of Northern Turkey. In: Mascle, A., Jolivet, L., eds., The Mediterranean Basins: Tertiary Extension within the Alpine Orogeny. Geological Society, London, Special Publications, 156: 475516

Okay, A. İ., Whitney, D. L., 2010. Blueschist, Eclogites, Ophiolites and Suture Zones in Northwest Turkey: A Review and a Field Excursion Guide. Ofioliti, 35: 131-172

Okay, A. İ., Zattin, M., Cavazza, W., 2010. Apatite FissionTrack Data for the Miocene Arabia-Eurasia Collision. Geology, 38: 35-38

Önen, A. P., 2003. Neotethyan Ophiolitic Rocks of the Anatolides of NW Turkey and Comparison with Tauride Ophiolites. Journal of Geological Society, London, 160: 947-962

Önen, A. P., Hall, R., 1993. Ophiolites and Related Metamorphic Rocks from the Kütahya Region, North-West Turkey. Geological Journal, 28: 399-412

Önen, A. P., Hall, R., 2000. Sub-Ophiolite Metamorphic Rocks from NW Anatolia, Turkey. Journal of Metamorphic Geology, 18: 483-495

Özgül, N., 1976. Some Geological Aspects of the Taurus Orogenic Belt (Turkey). Geological Society of Turkey Bulletin, 19: 65-78 (in Turkish with English Abstract)

Özgül, N., 1984. Stratigraphy and Tectonic Evolution of the Central Taurides. In: Tekeli, O., Göncüoğlu, M. C., eds., Geology of the Taurus Belt. Proceedings of International Symposium, Ankara. 77-90

Özgül, N., Arpat, E., 1973. Structural Units of the Taurus Orogenic Belt and Their Continuation in the Neighbouring Regions: Selection of Papers on the Eastern Mediterranean Region. Bulletin of Geological Society of Greece, 10: 155164

Özgül, N., Turşucu, A., 1984. Stratigraphy of the Mesozoic Carbonate Sequence of the Munzur Mountains (Eastern Taurides). In: Tekeli, O., Göncüoğlu, M. C., eds., Geology of the Taurus Belt. Proceedings of International Symposium, Ankara. 173-180

Pampal, S., 1984. Geology of Arslanköy-Tepeköy (Mersin) Regions. Selçuk Üniversitesi Fen-Edebiyat Fakültesi Fen Dergisi, 3: 247-258 (in Turkish with English Abstract)

Pampal, S., 1987. Geology of Güzeloluk-Sorgun (Mersin) Regions. Gazi Üniversitesi Mühendislik-Mimarlık Fakültesi Dergisi, 2: 143-174 (in Turkish with English Abstract)

Papanikolaou, D. J., Sideris, C., 1992. Post-Congress Field Trip to Chios-Lesbos. IGCP Project 276. 5th Meeting/6th Congress of the Geological Society of Greece, Athens

Parlak, O., 1996. Geochemistry and Geochronology of the Mersin Ophiolite within the Eastern Mediterranean Tectonic Frame (Southern Turkey): [Dissertation]. University of Geneva, Switzerland

Parlak, O., 2000. Geochemistry and Significance of Mafic Dyke Swarms in the Pozant1-Karsant1 Ophiolite (Southern
Turkey). Turkish Journal of Earth Sciences, 24: 29-38

Parlak, O., Delaloye, M., 1996. Geochemistry and Timing of Post-Metamorphic Dyke Emplacement in the Mersin Ophiolite (Southern Turkey): New Age Constraints from ${ }^{40} \mathrm{Ar} /{ }^{39} \mathrm{Ar}$ Geochronology. Terra Nova, 8: 585-592

Parlak, O., Delaloye, M., 1999. Precise ${ }^{40} \mathrm{Ar} /{ }^{39} \mathrm{Ar}$ Ages from the Metamorphic Sole of the Mersin Ophiolite (Southern Turkey). Tectonophysics, 301: 145-158

Parlak, O., Delaloye, M., Bingöl, E., 1995a. Geochemistry of the Volcanic Rocks in the Mersin Ophiolite (Southern Turkey) and Their Tectonic Significance in the Eastern Mediterranean Geology. In: Pişkin, Ö., Ergün, M., Savaşçın, M. Y., et al., eds., Proceedings of International Earth Science Colloquium on the Aegean Region, Dokuz Eylül University, İzmir, Turkey. 2: 441-458

Parlak, O., Delaloye, M., Bingöl, E., 1995b. Origin of Subophiolitic Metamorphic Rocks beneath the Mersin Ophiolite, Southern Turkey. Ofioliti, 20: 97-110

Parlak, O., Delaloye, M., Bíngöl, E., 1996. Mineral Chemistry of Ultramafic and Mafic Cumulates as an Indicator of the ArcRelated Origin of the Mersin Ophiolite (Southern Turkey). Geologische Rundschau, 85: 647-661

Parlak, O., Delaloye, M., Bingol, E., 1997. Geochemistry of the Volcanic Rocks in the Mersin Ophiolite (Southern Turkey) and Their Tectonic Significance in the Eastern Mediterranean Geology. In: Pişkin, Ö., Ergün, M., Savaşçın, M. Y., et al., eds., Proceeding of the International Earth Science Colloquium on the Aegean Region (IESCA-1995), 9-14 October, 1995, İzmir. 441-463

Parlak, O., Höck, V., Delaloye, M., 2000. Suprasubduction Zone Origin of the Pozanti-Karsanti Ophiolite (Southern Turkey) Deduced from Whole-Rock and Mineral Chemistry of the Gabbroic Cumulates. In: Bozkurt, E., Winchester, J. A., Piper, J. D. A., eds., Tectonics and Magmatism in Turkey and the Surrounding Area. Geological Society, London, Special Publications, 173: 219-234

Parlak, O., Höck, V., Delaloye, M., 2002. The Suprasubduction Pozanti-Karsanti Ophiolite, Southern Turkey: Evidence for High Pressure Crystal Fractionation of Ultramafic Cumulates. Lithos, 65: 205-224

Parlak, O., Karaoğlan, F., Rızaoğlu, T., et al., 2013. U-Pb and ${ }^{40} \mathrm{Ar} /{ }^{39} \mathrm{Ar}$ Geochronology of the Ophiolites and Granitoids from the Tauride Belt: İmplications for the Evolution of the Inner Tauride Suture. Journal of Geodynamics, 65: 22-37

Parlak, O., Rızaoğlu, T., Bağcı, U., et al., 2009. Tectonic Significance of the Geochemistry and Petrology of Ophiolites in Southeast Anatolia, Turkey. Tectonophysics, 473: $173-187$

Parlak, O., Robertson, A. H. F., 2004. Tectonic Setting and Evolution of the Ophiolite-Related Mersin Mélange, Southern Turkey: Its Role in the Tectonic-Sedimentary Setting of the Tethys in the Eastern Mediterranean Region. Geological Magazine, 141: 257-286

Parlak, O., Y1lmaz, H., Boztuğ, D., 2006. Geochemistry and Tectonic Setting of the Metamorphic Sole Rocks and Isolated Dykes from the Divriği Ophiolite (Sivas, Turkey): Evidence for Melt Generation within an Asthenospheric Window Prior to Ophiolite Emplacement. Turkish Journal 
of Earth Sciences, 15: 25-45

Parlak, O., Y1lmaz, H., Boztug, D., et al., 2005. Geochemistry and Tectonic Setting of Divriği Ophiolite in the East Central Anatolia (Sivas, Turkey): Evidence for Melt Generation within an Asthenospheric Window Prior to Ophiolite Emplacement onto the Taurides. International Symposium on the Geodynamics of Eastern Mediterranean: Active Tectonics of the Aegean Region, June 15-18, 2005, Kadir Has University, İstanbul, Turkey. 224

Peacock, S. M., 1988. Inverted Metamorphic Gradients in the Westernmost Cordillera. In: Ernst, W. G., ed., Metamorphism and Crustal Evolution of the Western United States, Rubey, 7: 953-975

Plunder, A., Agard, P., Chopin, C., et al., 2013. Geodynamics of the Tavşanlı Zone, Western Turkey: Insights into Subduction/Obduction Processes. Tectonophysics, 608: 884-903

Plunder, A., Agard, P., Chopin, C., et al., 2015. Accretion, Underplating and Exhumation along a Subduction Interface: From Subduction Initiation to Continental Subduction (Tavşanlı Zone, W. Turkey). Lithos, 226: 233-254

Poisson, A., 1977. Recherches Geologiques Dans Les Taurides Occidentals (Turquie): [Dissertation]. University of ParisSud, Orsay

Poisson, A., Şahinci, A., 1988. La Serie Mesozoique de Kemalpaşa et le Flysch Palaeocene d'İzmir au Nord-Ouest $\mathrm{du}$ Menderes (Anatolie Occidentale, Turquie); Un Jalon du Microcontinent Taurique (The Mesozoic Kemalpaşa Sequence and the Palaeocene Izmir Flysch of the Northwestern Menders Massif (Western Anatolia, Turkey); a Marker of the Tauric Microcontinent). Comptes Rendus de l'Academie des Sciences, 307: 1075-1080

Polat, A., Casey, J. F., 1995. A Structural Record of the Emplacement of the Pozant1-Karsant1 Ophiolite onto the Menderes-Taurus Block in the Late Cretaceous, Eastern Taurides, Turkey. Journal of Structural Geology, 17(12): 1673-1688

Polat, A., Casey, J. F., Kerrich, R., 1996. Geochemical Characteristics of Accreted Material beneath the Pozant1Karsant1 Ophiolite, Turkey: İntra-Oceanic Detachment, Assembly and Obduction. Tectonophysics, 263: 249-276

Pourteau, A., Candan, O., Oberhänsli, R., 2010. High-Pressure Metasediments in Central Turkey: Constraints on the Neotethyan Closure History. Tectonics, 29: TC5004

Rioux, M., Bowring, S., Kelemen, P., et al., 2013. Tectonic Development of the Semail Ophiolite: High Precision U-Pb Zircon Geochronology and Sm-Nd İsotopic Constraints on Crustal Growth and Emplacement. Journal of Geophysical Research, Solid Earth, 118: 1-17

Robertson, A. H. F., 2004. Development of Concepts Concerning the Genesis and Emplacement of Tethyan Ophiolites in the Eastern Mediterranean and Oman Regions. Earth Science Reviews, 66: 331-387

Robertson, A. H. F., Dixon, J. A., 1984. Introduction: Aspects of the Geological Evolution of the Eastern Mediterranean. In: Dixon, J. A., Robertson, A. H. F., eds., The Geological Evolution of the Eastern Mediterranean. Geological Society of London Special Publication, 17: 1-74
Robertson, A. H. F., Parlak, O., Metin, Y., et al., 2013. Late Palaeozoic-Cenozoic Tectonic Development of Carbonate Platform, Margin and Oceanic Units in the Eastern Taurides, Turkey. In: Robertson, A. H. F., Parlak, O., Ünlügenç, U. C., eds., Geological Development of Anatolia and the Easternmost Mediterranean Region. Geological Society, London, Special Publication, 372: 167-218

Robertson, A. H. F., Parlak, O., Ustaömer, T., 2009. Mélange Genesis and Ophiolite Emplacement Related to Subduction of the Northern Margin of the Tauride-Anatolide Continent, Central and Western Turkey. In: Van Hinsbergen, D. J. J., Edwards, M. A., Govers, R., eds., Collision and Collapse at the Africa-Arabia-Eurasia Subduction Zone. Geological Society, London, Special Publications, 311: 9-66

Robertson, A. H. F., Parlak, O., Ustaömer, T., 2012. Overview of the Palaeozoic-Neogene Evolution of Neotethys in the Eastern Mediterranean Region (Southern Turkey, Cyprus, Syria). Petroleum Geoscience, 18: 381-404

Robertson, A. H. F., Ustaömer, T., Parlak, O., et al., 2006. The Berit Transect of the Tauride Thrust Belt, S. Turkey: Late Cretaceous-Early Cenozoic Accretionary/Collisional Processes Related to Closure of the Southern Neotethys. Journal of Asian Earth Sciences, 27: 108-145.

Robertson, A. H. F., Waldron, J., 1990. Geochemistry and Tectonic Setting of Late Triassic and Late Jurassic-Early Cretaceous Basaltic Extrusives from the Antalya Complex, SW Turkey. In: Savaş̧̧ı, M. Y., Eronat, A. H., eds., Proceedings of International Earth Science Congress on Aegean Regions, October 1-6, 1990, Dokuz Eylül University, İzmir, Turkey. 2: 279-299

Robertson, A. H. F., Woodcock, N. H., 1980. Strike-Slip Related Sedimentation in the Antalya Complex, SW Turkey. Spec. Publ. Int. Ass. Sediment., 4: 127-145

Robertson, A. H. F., Woodcock, N. H., 1981a. Bilelyeri Group, Antalya Complex: Deposition on a Mesozoic Continental Margin in SW Turkey. Sedimentology, 28: 381-401

Robertson, A. H. F., Woodcock, N. H., 1981b. Alakırçay Group, Antalya Complex, SW Turkey: A Deformed Mesozoic Carbonate Margin. Sedimentary Geology, 30: 95-131

Robertson, A. H. F., Woodcock, N. H., 1981c. Gödene Zone, Antalya Complex SW Turkey: Volcanism and Sedimentation on Mesozoic Marginal Ocean Crust. Geologische Rundschau, 70: 1177-1214

Robertson, A. H. F., Woodcock, N. H., 1982. Sedimentary History of the Southwestern Segment of the Mesozoic-Tertiary Antalya Continental Margin, Southwestern Turkey. Eclogae Geol. Helv., 75: 517-562

Robertson, A. H. F., Woodcock, N. H., 1984. The SW Segment of the Antalya Complex, Turkey as a Mesozoic-Tertiary Tethyan Continental Margin. In: Dixon, J. A., Robertson, A. H. F., eds., The Geological Evolution of the Eastern Mediterranean. Geological Society of London Special Publication, 17: 251-271

Roddick, J. F., Cameron, W. E., Smith, A. G., 1979. PermoTriassic and Jurassic ${ }^{40} \mathrm{Ar}-{ }^{39} \mathrm{Ar}$ Ages from Greek Ophiolites and Associated Rocks. Nature, 279: 788-790

Şahinci, A., 1976. Late Norian Neritic and Early Senonian Pelagic Boztepe Unit to the North of Manisa (Western 
Anatolia-Turkey). Compte Rendu Academie des Science, 283: 1019-1020

Saka, S., Uysal, İ., Akmaz, R. M., et al., 2014. The Effects of Partial Melting, Melt-Mantle İnteraction and Fractionation on Ophiolite Generation: Constraints from the Late Cretaceous Pozant1-Karsant1 Ophiolite, Southern Turkey. Lithos, 202-203: 300-316

Sarp, H., 1976. Geological and Petrographical Investigations on Ophiolitic Units in the NW of Yeşilova (Burdur-Turkey): [Dissertation]. University of Geneva, Switzerland

Şenel, M., 1997a. 1/100 000 Ölçekli Türkiye Jeoloji Haritaları: Fethiye-L7 Paftas1, No: 1. Maden tetkik ve Arama Gemel Müdürlügü, Ankara, Turkey

Şenel, M., 1997b. 1 : 100000 Scale Geological Maps of Turkey: Fethiye-L7 Paftası, No. 2, Maden Tetkik ve Arama Gemel Müdürlüğü, Ankara, Turkey

Şenel, M., Selçuk, H., Bilgin, Z. R., et al., 1989. Geology of Çameli (Denizli)-Yeşilova (Burdur)-Elmalı (Antalya) and Surroundings. MTA Jeoloji Etüdleri Dairesi, Ankara, 9429: 344 (in Turkish with English Abstract)

Şengör, A. M. C., Yılmaz, Y., 1981. Tethyan Evolution of Turkey: A Plate Tectonic Approach. Tectonophysics, 75: 181-241. doi:10.1016/0040-1951(81)90275-4

Sherlock, S., Kelley, S., Inger, S., et al., 1999. ${ }^{40} \mathrm{Ar}-{ }^{39} \mathrm{Ar}$ and Rb$\mathrm{Sr}$ Geochronology of High-Pressure Metamorphism and Exhumation History of the Tavsanli Zone, NW Turkey. Contributions to Mineralogy and Petrology, 137(1-2): 4658. doi:10.1007/p100013777

Shervais, J. W., 2001. Birth, Death, and Resurrection: The Life Cycle of Suprasubduction Zone Ophiolites. Geochemistry, Geophysics, Geosystems, 2(1): 2000GC000080. doi:10.1029/2000gc000080

Spray, J. G., 1984. Possible Causes and Consequences of Upper Mantle Decoupling and Ophiolite Displacement. In: Gass, I. G., Lippard, S. J., Shelton, A. W., eds., Ophiolites and Oceanic Lithosphere. Geological Society, London, Special Publications, 13(1): 255-268. doi:10.1144/gsl.sp.1984.013.01.21

Spray, J. G., Roddick, J. C., 1980. Petrology and ${ }^{40} \mathrm{Ar} /{ }^{39} \mathrm{Ar}$ Geochronology of Some Hellenic Sub-Ophiolite Metamorphic Rocks. Contributions to Mineralogy and Petrology, 72: 43-55

Stern, R. J., Bloomer, S. H., 1992. Subduction Zone İnfancy: Examples from the Eocene Izu-Bonin-Mariana and Jurassic California. Geological Society of America Bulletin, 104: 1621-1636

Tekeli, O., Aksay, A., Urgun, B. M., et al., 1983. Geology of the Aladağ Mountains. In: Tekeli, O., Göncüoğlu, M. C., eds., Geology of the Taurus Belt. Proceedings of International Symposium on the Geology of the Tauride Belt, MTA Genel Müdürlüğü, Ankara, Turkey. 143-158

Tekin, U. K., Göncüoğlu, M. C., Turhan, N., 2002. First Evidence of Late Carnian Radiolarians from the IzmirAnkara Suture Complex, Central Sakarya, Turkey: Implications for the Opening Age of the Izmir-Ankara Branch of Neo-Tethys. Geobios, 35(1): 127-135. doi:10.1016/s0016-6995(02)00015-3

Thuizat, R., Montigny, R., Çakır, Ü., et al., 1978. K-Ar
Investigations on Two Turkish Ophiolites. In: Zartman, R. E., ed., Short Papers 4th International Conference Geochronology, Cosmochronology, Isotope Geology. Geological Survey of America Open-File Report, 78-701: 430-432

Thuizat, R., Whitechurch, H., Montigny, R., et al., 1981. K-Ar Dating of some Infra-Ophiolitic Metamorphic Soles from the Eastern Mediterranean: New Evidence for Oceanic Thrustings before Obduction. Earth and Planetary Science Letters, 52(2): 302-310. doi:10.1016/0012-821x(81)901850

Uysal, İ., Ersoy, E. Y., Karsl1, O., et al., 2012. Coexistence of Abyssal and Ultra-Depleted SSZ Type Mantle Peridotites in a Neo-Tethyan Ophiolite in SW Turkey: Constraints from Mineral Composition, Whole-Rock Geochemistry (MajorTrace-REE-PGE), and Re-Os Isotope Systematics. Lithos, 132-133: 50-69. doi:10.1016/j.lithos.2011.11.009

Van der Kaaden, G., 1966. Importance and Distribution of Glaucophane Bearing Rocks in Turkey. Maden Tetkik ve Arama Enstitüsü Dergisi, 67: 38-69

Vergili, Ö., Parlak, O., 2005. Geochemistry and Tectonic Setting of Metamorphic Sole Rocks and Mafic Dykes from the Pınarbaşı (Kayseri) Ophiolite, Central Anatolia. Ofioliti, 30: $37-52$

Wakabayashi, J., Dilek, Y., 2003. What Constitutes 'Emplacement' of an Ophiolite? Mechanisms and Relationship to Subduction Initiation and Formation of Metamorphic Soles. Geological Society, London, Special Publications, 218(1): 427-447. doi:10.1144/gsl.sp.2003.218.01.22

Warren, C. J., Parrish, R. R., Waters, D. J., et al., 2005. Dating the Geologic History of Oman's Semail Ophiolite: Insights from U-Pb Geochronology. Contributions to Mineralogy and Petrology, 150(4): 403-422. doi:10.1007/s00410-0050028-5

Whitechurch, H., Juteau, T., Montigny, R., 1984. Role of the Eastern Mediterranean Ophiolites (Turkey, Syria, Cyprus) in the History of the Neo-Tethys. In: Dixon, J. A., Robertson, A. H. F., eds., The Geological Evolution of the Eastern Mediterranean. Geological Society, London, Special Publications, 17: 301-317

Williams, H., Smyth, W. R., 1973. Metamorphic Aureoles beneath Ophiolite Suites and Alpine Peridotites; Tectonic Implications with West Newfoundland Examples. American Journal of Science, 273(7): 594-621. doi:10.2475/ajs.273.7.594

Yılmaz, H., Arıkal, T., Yılmaz, A., 2001. Geology of the Güneş Ophiolite (Divriği-Sivas). Proceedings of the 54th Geological Congress of Turkey, May 7-10, 2001, Ankara, 54-65 (in Turkish with English Abstract)

Y1lmaz, H., Y1lmaz, A. 2004. Geology and Structural Evolution of the Divriği (Sivas) Region. Türkiye Jeoloji Bülteni, 47: 13-45 (in Turkish with English Abstract)

Y1lmaz, P. O., 1984. Fossil and K-Ar Data for the Age of of the Antalya Complex, SW Turkey. In: Dixon, J. A., Robertson, A. H. F., eds., The Geological Evolution of the Eastern Mediterranean. Geological Society, London, Special Publication, 17: 335-347 